\author{
UNIVERSIDADE DE SÃO PAULO \\ FACULDADE DE ODONTOLOGIA DE RIBEIRÃO PRETO \\ PÓS-GRADUAÇÃO EM PERIODONTIA
}

\title{
EXPRESSÃO DOS FENÓTIPOS \\ FIBROBLÁSTICO E OSTEOBLÁSTICO EM \\ CULTURAS TRIDIMENSIONAIS NA PRESENÇA DE PARTÍCULAS DE VIDRO BIOATIVO
}

LUCIANA BASTOS ALVES

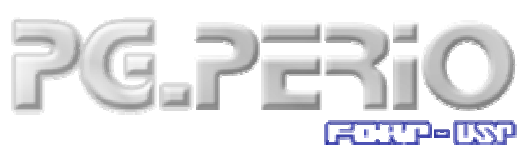

RIBEIRÃO PRETO 


\title{
EXPRESSÃO DOS FENÓTIPOS FIBROBLÁSTICO E OSTEOBLÁSTICO EM CULTURAS TRIDIMENSIONAIS NA PRESENÇA DE PARTÍCULAS DE VIDRO BIOATIVO
}

\author{
Tese apresentada à Faculdade de \\ Odontologia de Ribeirão Preto da \\ Universidade de São Paulo, para \\ obtenção do título de Doutor em \\ Periodontia.
}

Área de concentração: Periodontia

Orientador: Profa. Dra. Daniela Bazan Palioto Coorientador: Prof. Dr. Paulo Tambasco de Oliveira 
AUTORIZO A REPRODUÇÃO E DIVULGAÇÃO DO TEOR TOTAL OU PARCIAL DESTE TRABALHO, POR QUALQUER MEIO CONVENCIONAL OU ELETRÔNICO, PARA FINS DE ESTUDO E PESQUISA, DESDE QUE CITADA A FONTE.

Ficha catalográfica elaborada pela Biblioteca Central do Campus USP - Ribeirão Preto

Alves, Luciana Bastos

Expressão dos fenótipos fibroblático e esteoblástico em culturas tridimensionais na presença de partículas de vidro bioativo.

Ribeirão Preto, 2012.

164 p.: il.; $30 \mathrm{~cm}$

Tese de Doutorado apresentada à Faculdade de Odontologia de Ribeirão Preto/USP. Área de Concentração: Periodontia.

Orientador: Palioto, Daniela Bazan.

Coorientador: Oliveira, Paulo Tambasco de.

1. Cultura tridimensional. 2. Vidro bioativo. 3. Fibroblastos.

4. Osteoblastos 
Trabalho no Laboratório de Cultura de Células Departamento de CTBMF e Periodontia da Faculdade de Odontologia de Ribeirão Preto da Universidade de São Paulo, com auxílio financeiro da Fundação de Amparo à Pesquisa do Estado de São Paulo (FAPESP), processo número: 2009/15.525-6. 
FOLHA DE APROVAÇÃO

Luciana Bastos Alves

Tese apresentada à Faculdade de Odontologia de Ribeirão Preto da Universidade de São Paulo, para obtenção do título de Doutor em Periodontia.

Área de concentração: Periodontia.

Aprovado em:

Banca Examinadora

1) Prof.(a). Dr.(a).:

Instituição:

Assinatura:

2) Prof.(a). Dr.(a).:

Instituição:

Assinatura:

3) Prof.(a). Dr.(a).:

Instituição:

Assinatura:

4) Prof.(a). Dr.(a).:

Instituição:

Assinatura:

5) Prof.(a). Dr.(a).:

Instituição:

Assinatura: 
Dedicatória 
Aos meus pais José Edmar e Maria Lúcia, que sempre me apoiaram e incentivaram em toda a minha vida, não medindo esforços para me proporcionar a melhor formação. Sem vocês nada disso seria possível. Muito obrigada! 
Agradecimento Especial 
A Deus,

pelo o dom da vida.

A Nossa Senhora Desatadora dos Nós, Por tornar mais fáceis os momentos mais difíceis.

\begin{abstract}
À minha família, especialmente, ao meu irmão Rafael, pelo estímulo e carinho, aos meus avós Lysia e Geraldo, meu maior exemplo de família e vida, e as minhas queridas tias Gracinha e Zó, pelo carinho e força que vocês sempre me oferecem.
\end{abstract}

Ao Antônio (Tony), por compartilhar todas as etapas, me apoiando, me trazendo forças e me incentivando. Muito obrigada por toda a paciência e companheirismo. 
Agradecimentos 
À Fundação de Amparo à Pesquisa do Estado de São Paulo (FAPESP) pelo auxílio financeiro para realização deste trabalho.

Á Coordenação De Aperfeiçoamento De Pessoal De Nível Superior (CAPES), pela bolsa de doutorado concedida.

À Faculdade de Odontologia de Ribeirão Preto da Universidade de São Paulo.

Ao Programa de Pós-graduação da Faculdade de Odontologia de Ribeirão Preto.

Ao Departamento de Cirurgia e Traumatologia Buco-Maxilo-Facial e Periodontia

À orientadora deste trabalho Profa. Dra. Daniela Bazan Palioto, pela orientação, confiança e estímulo nos momentos difíceis da realização dete trabalho.

Ao co-orientador Prof. Dr. Paulo Tambasco de Oliveira, pelos ensinamentos e conhecimentos passados, e pela sua contribuição na realização do trabalho.

Ao técnico do Laboratório de Cultura de Células Roger Rodrigues Fernandes, por sua amizade, disponibilidade, paciência e dedicação em me ensinar e ajudar no laboratório.

À aluna de pós-doutorado Viviane Mariguela que foi essencial na execução deste trabalho me ajudando com os experimentos do PCR e principalmente com a sua amizade, apoio e carinho.

Ao professor Dr. Arthur Belém Novaes Jr, pela oportunidade e confiança, pela convivência e ensinamentos na clínica do PAE, orientação no projeto clínico e pelo exemplo de pesquisador.

Aos professores do curso de Periodontia Márcio Fernando de Moraes Grisi, Sérgio Luís Scombatti de Souza e Mário Taba Jr, pelo apoio e aprendizado na clínica. E ao professor Michel Messora, pela força na reta final. 
A todos os professores que contribuíram para minha formação, serei eternamente grata a todos vocês.

Aos amigos do Laboratório de Cultura de Células: Lucas Novaes, Larissa de Castro, Larissa Sverzutti, Manu Ferraz, Olívia, Patrícia Adachi, Gabriela, Willian, Rogério Kato e Tiago, pela ajuda e convivência diária.

À técnica do laboratório de cultura de células Mila Siprione, pela prestatividade auxílio na realização deste trabalho e pela amizade, carinho e força.

Á profa. Dra. Vanessa Freitas, por sua contribuição em algumas etapas importantes da metodologia do trabalho, pela sua disponibilidade e contribuição científica.

À Débora Campanella Bastos, pela disponibilidade e ajuda em algumas etapas da realização do trabalho.

Á técnica da microscopia Adriana, pela disponibilidade, ajuda, amizade e incentivo.

À técnica da microscopia confocal Elizabete (Bete), pela paciência, convívio e sua disponibilidade.

Aos alunos de iniciação científica: Beatriz Steque e Sandro Bornelli, pela ajuda no laboratório e pela agradável convivência.

A todos os funcionários da FORP pelo profissionalismo, atenção e amizade ao longo desses anos de convivência, em especial Tatiana, Dulce, Suely, Zilda, Fabíola, Sebastião, Isabel Sola e Regiane Moi.

Às amigas do doutorado, Priscila, Adriana e Flávia, que me receberam de braços abertos desde o primeiro dia da seleção do doutorado como se eu já fizesse parte da turma, pelo apoio, carinho e amizade e alegre convivência. Vocês estarão sempre comigo! 
Aos colegas e amigos da pós-graduação Andréa, Danilo, Janine, Carolina Delmondes, Carolina Scanavez, Igor, Lívia, Lauro, Umberto e Cristine por compartilharem os momentos desta trajetória. Em especial a Patrícia Garani pela convivência diária e momentos de alegria em nossa casa, por toda força e companherismo. A Luciana Maia e Carolina Mandetta pela grande ajuda na clínica e no laboratório durante a execução do trabalho e pelo carinho e amizade de vocês.

As amizades contruídas em Ribeirão Preto que me proporcionaram momentos alegres e motivação: Priscila Nóbrega, Natália e Fábio, Mariana Piva, Juliana Cavalcante, Késsia Mesquita, Marina, Daniele Azevedo, Ira, Giovana e Geraldo. Em especial a Karina, que mesmo em pouco tempo de convivência em nossa casa, me trouxe carinho, força e amizade principalmente nesta etapa final.

Aos meus amigos de Natal que mesmo distante estavam torcendo por mim. Em especial a minha querida amiga Renata Filgueira que também veio para Ribeirão Preto fazer sua pós-graduação e me trouxe o aconchego de casa, o carinho de uma amizade verdadeira, uma força muito importante nos momentos difíceis e muita alegria e boas vibrações.

As minhas queridas primas Nathália Bastos e Ludmila Alves, colegas de profissão e irmãs de coração, que sempre se fizeram presente mesmo distante me apoiando e me incentivando.

A todos que, direta ou indiretamente, contribuíram para a realização deste trabalho. 
Resumo

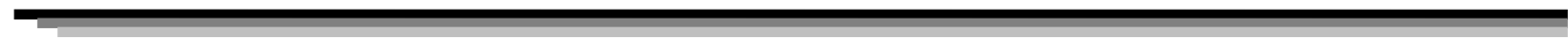


ALVES, L. B. Expressão dos fenótipos fibroblástico e osteoblástico em culturas tridimensionais na presença de partículas de vidro bioativo. 2012. 164 p. Tese (Doutorado em Periodontia) - Faculdade de Odontologia de Ribeirão Preto, Universidade de São Paulo, Ribeirão Preto, 2012.

O objetivo deste estudo foi analisar a expressão dos fenótipos fibroblástico e osteoblástico em culturas tridimensionais na presença ou não de partículas de vidro bioativo. Fibroblastos derivados do ligamento periodontal humano (hPDLF) e células osteogênicas da calvária de rato recém-nascisdos foram plaqueadas em superfícies bidimensionais - lamínulas de plástico Thermanox ${ }^{\mathrm{TM}}$ (controle); superfícies colágenas bidimensionais - Thermanox ${ }^{\mathrm{TM}}$ revestidas por colágeno I sem partículas de vidro bioativo (2D) e com partículas de vidro bioativo (2D+VB); e em gel colágeno tridimensional sem vidro bioativo (3D) e com partículas (3D+VB). Foram avaliados: Viabilidade celular (MTT) nos tempos 3, 7 e 10 dias; Atividade de fosfatase alcalina (ALP) normalizada pelo conteúdo de proteína total em 7 e 14 dias; Immunolocalização de proteínas da matriz não-colágena (ALP e OPN em células hPDLF aos 7 e 14 dias e OPN e BSP em células osteogênicas aos 7 dias) por imunofluorescência indireta; Expressão quantitativa (PCR em tempo real) dos genes Periostina (PRT), Calcium-Binding Protein (S100A4) e Fibromodulina (FBM), marcadores do fenótipo fibroblástico, em células hPDLF e Fosfatase Alcalina (ALP), Osteopontina (OPN), Sialoproteína Óssea (BSP), Osteocalcina (OC), Colágeno I (COL I) e Runx2, marcadores osteoblásticos, em ambos os tipos celulares; e Mineralização (coloração por vermelho de Alizarina). Os resultados obtidos nas culturas de hPDLF mostraram que aos 3 dias a viabilidade celular em 2D+VB foi maior que no controle $(p<0,05)$ e nenhuma diferença significante entre os grupos foi observada aos 7 e 10 dias. $O$ conteúdo de proteína total aos 7 e 14 dias foi maior nas culturas $3 \mathrm{D}$ e $3 \mathrm{D}+\mathrm{VB}$, sendo aos 7 dias significantemente diferente de $2 \mathrm{D}+\mathrm{VB}$ $(p<0,05)$ e controle $(p<0,05)$ e aos 14 dias obsevou-se diferença significativa entre $3 \mathrm{D}$ e 2D. A atividade de ALP aos 7 dias foi maior nos grupos 2D e 2D+VB comparados com 3D $(p<0,05)$ e 3D+VB $(p<0,05)$; e em 3D+VB menor que no controle $(p<0,05)$. Entretanto, aos 14 dias $3 \mathrm{D}$ e $3 \mathrm{D}+\mathrm{VB}$ apresentaram maior atividade de ALP que o controle $(p<0,05)$. Imunomarcações para OPN e ALP foram observadas nas células em 3D em ambos os períodos avaliados, e em 2D, 2D+VB, e controle apenas aos 14 dias. A expressão de RNAm para PRT aos 7 dias apresentou um perfil upregulated em 3D e 3D+VB comparados ao controle $(p<0,05)$; para FBM a expressão gênica foi maior em $3 D$ e $2 D$ que em $3 D+V B(p<0,05)$, e menor em 3D+VB comparado ao controle $(p<0,05)$. As células em 2D exibiram maiores níveis de expressão de RNAm para S100A4 que as cultivadas em 2D+VB $(p<0,05)$ e controle $(p<0,05)$. Os níveis de RNAm para COL I e ALP em 2D+VB e 3D, para RUNX2 e OPN em 3D e 2D, e para OC em 2D apresentaram-se upregulated em relação ao controle $(p<0,05)$. Em 2D o nível de expressão de OC foi maior que em 2D+VB $(p<0,05)$. Aos 14 dias houve uma diminuição da expressão de todos os genes analisados em relação às análises de 7 dias. Células em 3D+VB expressaram menores níveis de PRT que em $2 \mathrm{D}+\mathrm{VB}(p<0,05)$. A expressão de RNAm para FBM foi maior em 2D e 2D+VB e para S100A4 maior em 2D comparado com 3D $(p<0,05)$, nos quais os níveis de S100A4 ficaram downregulated com relação ao controle. COL I e ALP apresentaram-se downregulated em 3D $(p<0,05)$ e 3D+VB $(p<0,05)$ em relação ao controle. Entre $2 D+V B$ e $3 D+V B$ também foi observada diferença significativa para ALP. A expressão de RUNX2 foi maior em 3D que em $3 \mathrm{D}+\mathrm{VB}(p<0,05)$ e de OC maior no controle. Nos grupos com VB foi observada maior 
formação de matriz calcificada aos 10 e 14 dias. Aos 10 dias não foram observadas áreas coradas por Alizarina através da microscopia, mas a quantidade de mineralização em 2D+VB e 3D+VB foi significativamente maior que no controle $(p<0,05), 2 \mathrm{D}(p<0,05)$ e 3D $(p<0,05)$. Aos 14 dias marcações mais extensas foram observadas nas culturas com VB, porém os nódulos mineralizados apresentavam-se independentes das partículas. 2D+VB e 3D+VB foram siginificativamente diferentes do controle $(p<0,05)$ e 2D $(p<0,05)$. As culturas de células osteogênicas mostraram que aos 7 dias as células crescidas sobre os arcabouços 3D+VB e 3D exibiram menores índices de viabilidade. Diferenças significativas foram observadas quando $3 \mathrm{D}+\mathrm{VB}$ foi comparado aos grupos 2D+VB $(p<0,05)$ e controle $(p<0,05)$; e entre 2D e 3D $(p<0,05)$. Aos 3 e 10 dias não foram encontradas diferenças significativas na viabilidade celular entre os grupos. O conteúdo de proteína total foi maior em 3D+VB que em 2D+VB $(p<0,05)$ e no controle $(p<0,05)$ aos 7 e 14 dias. Diferenças significantes também foram observadas entre $3 D$ e $2 D(p<0,05)$ aos 14 dias. A atividade de ALP aos 7 dias foi maior em 2D+VB e 3D+VB. Diferenças significantes foram encontradas entre 2D e 2D+VB $(p<0,05)$, 3D e 3D+VB $(p<0,05)$ e entre 3D e controle $(p<0,05)$. Entretanto, aos 14 dias, 3D e 3D+VB apresentaram os menores valores de atividade de ALP, sendo a significantemente diferentes de 2D $(p<0,05)$ e 2D+VB $(p<0,05)$. Imunomarcações para OPN e BSP foram observadas aos 7 dias em 2D, 2D+VB, 3D e controle. Aos 7 dias os níveis expressão do RNAm para ALP, COL I e RUNX2 foram maiores em 3D e 3D+VB. Os genes OPN, OC e BSP exibiram níveis de expressão mais altos em 2D+VB. A expressão de COL I foi maior em 3D+VB que em 2D+VB $(p<0,05)$. As células em 2D+VB apresentaram maiores níveis de expressão de OPN e OC que em 2D $(p<0,05)$ e 3D+VB $(p<0,05)$, nos quais a expressão desses genes e de BSP estavam downregulated em relação ao grupo controle. Aos 10 e 14 dias áreas coradas por vermelho de Alizarina foram observadas em todos os grupos, sendo mais extensas nos grupos que continham VB. Aos 10 dias a quantidade de cálcio em 3D+VB foi maior que no controle $(p<0,05)$; e maior em 2D+VB comparado com 2D $(p<0,05)$ e controle $(p<0,05)$. Aos 14 dias 2D+VB e 3D+VB apresentaram uma quantidade de cálcio siginificativamente maior que no controle $(p<0,05)$ e em 2D $(p<0,05)$. Em conclusão, este estudo demonstrou que os arcabouços tridimensionais colágenos são capazes de suportar a viabilidade, proliferação e diferenciação celular se in vitro de hPDLF e células osteogênicas derivadas de calvária de rato recém-nascidos e de favorecerem a expressão dos fenótipos fibroblástico e osteoblástico em hPDLF. As partículas de VB em ambos os tipos celulares também contribuiram para viabilidade, diferenciação, formação de matriz mineralizada e expressão fenotípica.

Palavras-chave: cultura de células tridimensional, colágeno, vidro bioativo, células osteogênicas, fibroblastos do ligamento periodontal 
Abstract 
ALVES, L. B. Osteoblastic and fibroblastic phenotypes expression on three dimensional cell cultures in the presence of bioactive glass particles. 2012. 164 p. Tese (Doutorado em Periodontia) - Faculdade de Odontologia de Ribeirão Preto, Universidade de São Paulo, Ribeirão Preto, 2012.

The aim of this study was to analyze the fibroblastic and osteoblastic phenotypes expression on three-dimensional cultures in the presence or not of bioactive glass particles. Fibroblasts derived from human periodontal ligament (hPDLF) and osteogenic cells from newborn rat calvaria were cultured on bi-dimensional surfaces plastic coverslips Thermanox ${ }^{\mathrm{TM}}$ (control), bi-dimensional collagen surfaces Thermanox ${ }^{\mathrm{TM}}$ coated with collagen I without bioactive glass particles (2D) and with bioactive glass particles $(2 \mathrm{D}+\mathrm{BG})$, on three-dimensional collagen gel without bioactive glass (3D) and with particles (3D+BG). Were evaluated: Cell viability (MTT) in 3 days, 7 and 10 days; Phosphatase alkaline activity (ALP) normalized by total protein content at 7 and 14 days; Immunolocalization of non-matrix proteins collagen (ALP and OPN in hPDLF at 7 and 14 days, OPN and BSP in osteogenic cells at 7 days) by indirect immunofluorescence; Genes expression (real-time PCR) for Periostin (PRT), Calcium-Binding Protein (S100A4) and Fibromodulin (FBM): fibroblastic markers in hPDLF, and Alkaline phosphatase (ALP), Osteopontin (OPN), Bone sialoprotein (BSP), Osteocalcin (OC), Collagen I (COL I) and RUNX2: osteoblastic markers in both cell types; and Mineralization (staining with Alizarin red). The results obtained on hPDLF cultures showed that cell viability on 2D+BG was higher than on control at 3 days $(p<0.05)$, and no significant difference between groups was observed at 7 and 10 days. The total protein content at 7 and 14 days was higher on 3D and 3D+BG cultures compared those on 2D+BG $(p<0.05)$ and control $(p<0.05)$ at 7 days. Significant difference was also observed between 3D and $2 \mathrm{D}$ at 14 days. The ALP activity at 7 days was higher on $2 \mathrm{D}$ and $2 \mathrm{D}+\mathrm{BG}$ compared with 3D $(p<0.05)$ and $3 D+B G(p<0.05)$, it was also lower on 3D+BG than on control $(p<0.05)$. However, at 14 days $3 \mathrm{D}$ and $3 \mathrm{D}+\mathrm{BG}$ showed higher ALP activity than control $(p<0.05)$. Immunolabeling for OPN and ALP were observed in cells on $3 D$ at both periods and on 2D, 2D+ BG and control only at 14 days. At 7 days, the expression of mRNA for PRT was upregulated on 3D and 3D+BG compared with control $(p<0.05)$, for the FBM it was higher on $3 D$ and $2 D$ than on $3 D+B G(p<0,05)$, but it was lower on 3D+BG than on control $(p<0.05)$. Cells on 2D exhibited higher levels of S100A4 mRNA expression than those grown on 2D+BG $(p<0.05)$ and control $(p<0.05)$. The mRNA levels expression for COL I and ALP on 2D+BG and 3D, and for RUNX2 and OPN on 3D and 2D, and for OC on 2D presented upregulated compared with control $(p<0.05)$. Also, cells on $2 \mathrm{D}$ showed the level expression of $\mathrm{OC}$ higher than those on and 2D+BG $(p<0.05)$. At 14 days, there was a decrease in all evaluated genes expression compared with 7 days analyses. Cells on 2D+BG expressed higher levels of PRT than on 3D+BG $(p<0.05)$. 2D and 2D+BG showed the highest levels of mRNA expression for FBM. Gene expression of S100A4 on 2D was higher than on $3 D(p<0.05)$ and $3 D+B G(p<0.05)$, in which the levels of S100A4 were downregulated compared to control. COL I and ALP were downregulated on $3 \mathrm{D}$ $(p<0.05)$ and on $3 D+B G(p<0.05)$ compared with control. There was also a significant difference between $2 \mathrm{D}+\mathrm{BG}$ and $3 \mathrm{D}+\mathrm{BG}$ for mRNA ALP expression. RUNX2 expression was higher on $3 D$ than on $3 D+B G(p<0.05)$, and $O C$ expression was higher on control. Calcified matrix formation was observed on BG cultures at 10 and 14 days. At 10 days, areas stained by Alizarin were no observed by microscopy, but 
the amount of mineralization on $2 \mathrm{D}+\mathrm{BG}$ and $3 \mathrm{D}+\mathrm{BG}$ was significantly higher than on control $(p<0.05), 2 \mathrm{D}(p<0.05)$ and $3 \mathrm{D}(p<0.05)$. At 14 days, more extensive staining was observed on cultures with $B G$, but the mineralized nodules formation was independent of the particles. Calcium content on 2D+BG and 3D+BG was significantly higher than control $(p<0.05)$ and 2D $(p<0.05)$. Osteogenic cell cultures showed that cells grown on 3D and 3D+BG surfaces exhibited the lowest levels of cell viability. Significant differences were observed when 3D+BG was compared with 2D+BG $(p<0.05)$ and control $(p<0.05)$ and also between 2D and 3D $(p<0.05)$. At 3 and 10 days, there were no significant differences for cell viabililty between the cultures. The total protein content was higher on 3D+BG than on the control $(p<0.05)$ and 2D+BG $(p<0.05)$ at 7 and 14 days. Significant differences were also observed between 3D and 2D $(p<0.05)$ at 14 days. ALP activity at 7 days was higher on $2 D+B G$ and $3 D+B G$. Significant differences were found between $2 D$ and $2 D+B G$ $(p<0.05), 3 \mathrm{D}$ and 3D+BG $(p<0.05)$, and between 3D and control $(p<0.05)$. However, at 14 days $3 D$ and $3 D+B G$ had the lowest levels of ALP activity, significantly different from 2D $(p<0.05)$ and 2D+BG $(p<0.05)$. Immunolabeling for OPN and BSP were observed at 7 days on 2D, 2D+BG, 3D and control. At 7 days, the expression levels of mRNA for ALP, COL I and RUNX2 were higher on 3D and 3D+BG. OPN, BSP and $\mathrm{OC}$ exhibited higher expression levels on 2D+BG. COL I expression was higher on $3 D+B G$ than on $2 D+B G(p<0.05)$. Cells on 2D+BG showed higher expression levels of OPN and OC than those on 2D $(p<0.05)$ and 3D+BG $(p<0.05)$, in which both of these genes and BSP expression were downregulated compared with control. At 10 and 14 days areas stained with Alizarin red were observed all evaluated groups, especially on BG cultures. At 10 days the amount of calcium on 3D+BG was higher than on control $(p<0.05)$, and it was also higher on $2 \mathrm{D}+\mathrm{BG}$ compared with $2 \mathrm{D}$ $(p<0.05)$ and control $(p<0.05)$. At 14 days, 2D+BG and 3D+BG showed greater calcium amount than control $(p<0.05)$ and $2 \mathrm{D}(p<0.05)$. In conclusion, this study demonstrated that in vitro 3D cultures of hPDLF and osteogenic cells from newborn rats calvaria were able of support cell viability, differentiation, and to contribute to expression of fibroblastic and osteoblastic phenotype in hPDLF. The BG particles also favored the viability, differentiation, mineralized matrix formation and phenotypic expression in both cell types.

Keywords: three-dimensional cell culture, collagen, bioactive glass, osteogenic cells, periodontal ligament fibroblasts. 


$$
-
$$


Material e Métodos

Página

Tabela 1

61

Tabela 2

61

\section{Capítulo I}

Figura 1

Figura 2

Figura 3

68

Figura 4

69

Figura 5

70

Figura 6

72

Figura 7

72

Figura 8 73

Figura 9 74

Figura 10

74

Figura 11 75

Figura 12 75

Figura 13 76

Figura 14 77

Figura 15 78

\section{Capítulo II}

Figura 16

99

Figura 17

100

Figura 18

101

Figura 19

102

Figura 20

103

Figura 21 104

Figura 22 105

Figura 23 106 
Lista de Abreviaturas e Siglas 
$\%$ : porcentagem

${ }^{\circ} \mathrm{C}$ : grau Celsius

2D: bidimensional

3D: tridimensional

ACTB: actina beta

ALP: fosfatase alcalina

BMPs: proteínas ósseas morfogenéticas (do inglês: bone morphogenetic proteins)

BSP:sialoproteína óssea

Ca: cálcio

$\mathrm{Ca}_{3}\left(\mathrm{PO}_{4}\right)_{2}$ : fosfato de cálcio

CaO: óxido de cálcio

cDNA: ácido desoxirribonucleico complementar

$\mathrm{cm}^{2}$ : centímetro quadrado

COL I: colágeno tipo I

Col-Ti; superfície de titânio revestida de colágeno

Ct: ciclo limiar (cicle threshold)

DAPI: diamidina 2 phenylindole dihydrochloride

DEPC: dietylprocarbonate

DMEM: meio modificado por Egle (do inglês: Dubecco Medium Egle Modified)

DNA: ácido desoxirribonucleico

dNTP: desorribonuleotídeo trifosfatado

EDTA: ácido etilenodiamino tetra-acético (do inglês: Ethylenediamine tetraacetic acid)

FBM: fibromodulina

FBS: soro fetal bovino (do inglês: fetal bovine serum)

h: hora

$\mathrm{H}^{+}$: íons hidrogênio

HÁ: hidroxiapatita

HCA: hidroxiapatita carbonada

HCL: ácido clorídrico

hPDL: células do ligamento periodontal humano (do inglês: humam periodontal ligament)

hPDLF: fibroblastos do ligamento periodontal humano (do inglês: humam periodontal ligament fibroblast) 
IGF: fator de crescimento à insulina (do inglês: Insulin-like growth fator)

M: massa molar

MC3T3E1: linhagem de célula osteoblástica

MEC: matriz extracelular

mg: miligrama

min.: minuto

min: minuto

ml: mililitro

mm: milímetro

mM: milimolar

MTT: thiazolyl blue tetrazolum bormide

n: número

$\mathrm{NaHCO}_{3}$ : bicarbonato de sódio

$\mathrm{NaO}$ : óxido de sódio

$\mathrm{NaOH}$ : hidróxido de sódio

ng: nanograma

nM: nanomolar

$\mathrm{nm}$ :namometro

NS: não significante

OC: osteocalcina

OPN: osteopontina

$\mathrm{P}_{2} \mathrm{O}_{5}$ : pentóxido de fósforo

PB: tampão fosfato (do inglês: phosphate buffer)

PBS: solução tampão salina de fosfato (do inglês: Phosphate Bufferedd Saline)

PDGF: fator de crescimento derivados das plaquetas (do inglês:platelet-derived

growth fator)

PDL: ligamento periodontal (do inglês: periodontal ligament)

PGA: ácido poliglicólico (do inglês: polyglycolic acid)

PLGA: ácido glicólico lático ou polilático (do inglês: poly (lactic-co-glycolic acid))

PRT: Periostina

RNA: ácido ribonucléico

RNAse: enzima ribonuclease

RT-PCR: reação em cadeia de polimerase em tempo real 
RT-PCR: Reaçãoda transciptase reversa seguida de reação em cadeia da polimerase (do inglês: Reverse Transcriptase- Polimerase Chain Reaction)

RUNX2: (do ingles: Runt-related transcription factor 2)

s: segundo

S100A4: proteína da família S100 de proteínas ligadoras do cálcio

Si: sílica

$\mathrm{SiO}^{2}$ : dióxido de sílica

TA: temperatura ambiente

TCP: fosfato tricálcio (do inglês: tricalcium phosphate)

TGF- $\beta$ : fator de crescimento e transformação beta (do inglês: transforming growth factor beta)

TIFF: (do inglês: tagged image file format)

VB: vidro bioativo

a-MEM: meio essencial mínimo modificação alfa (do inglês: Minimum Essential Medium Eagle)

$\mu \mathrm{g}$ : micrograma

$\mu \mathrm{l}$ : microlitro 
Sumário 
2. REVISÃO DE LITERATURA

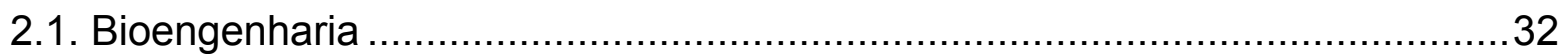

2.2. Colágeno

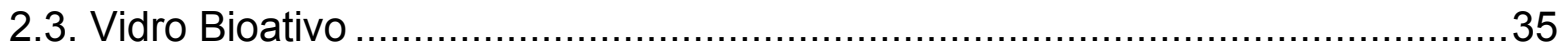

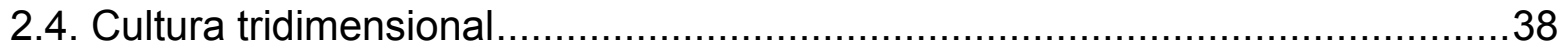

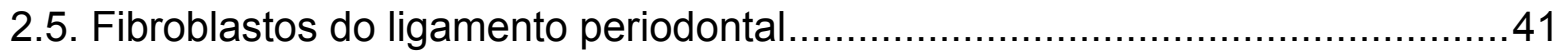

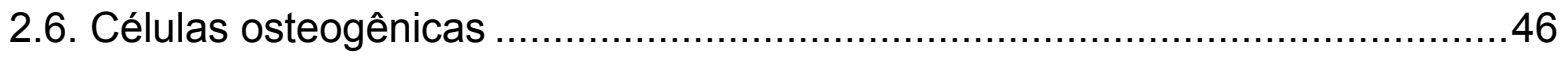

3. PROPOSIÇÃO

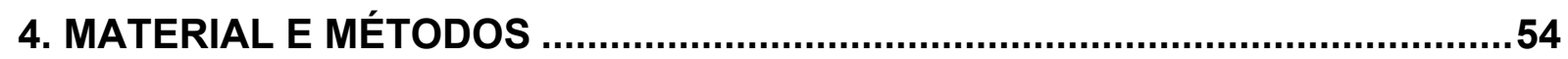

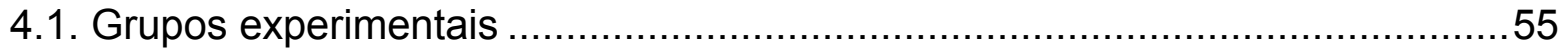

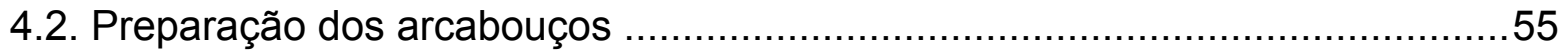

4.3. Isolamento e cultura dos fibroblastos do ligamento periodontal humanos .......56

4.4. Isolamento das células e cultura primária de células osteogênicas ................57

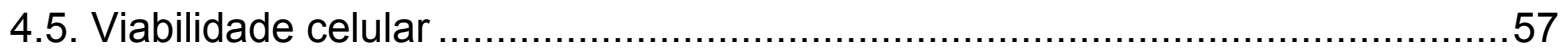

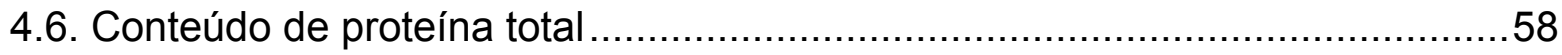

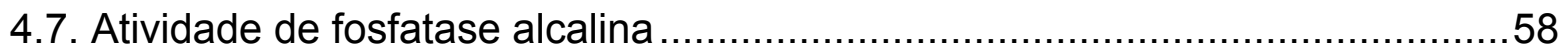

4.8. Localização de proteínas da matriz extracelular não-colágena por

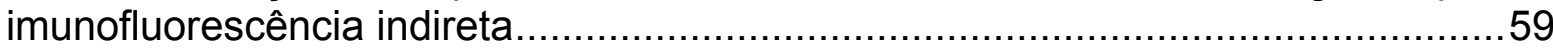

4.9. Expressão quantitativa dos genes por reação em cadeia da polimerase em

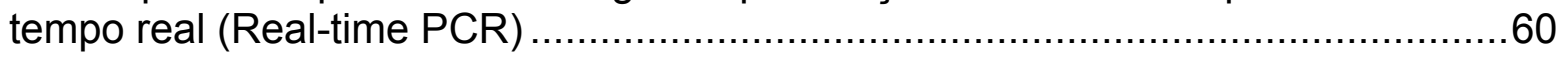

4.9.1. Extração de RNA total para PCR em tempo real ...................................60

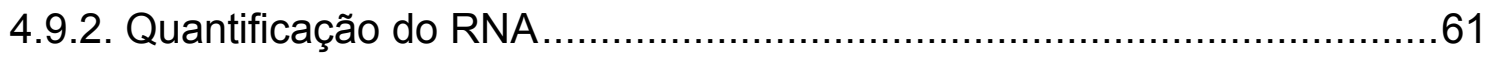

4.9.3. Confecção da fita de DNA complementar (cDNA) ................................61

4.9.4. Reação em cadeia da polimerase (PCR) em tempo real .......................62

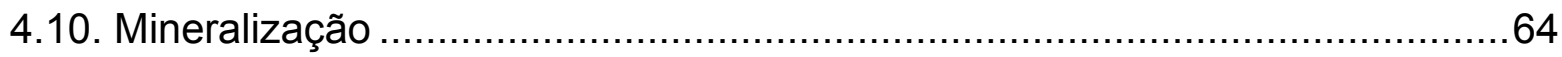

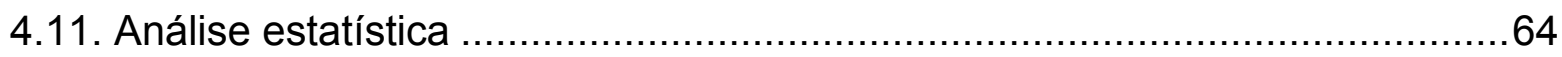

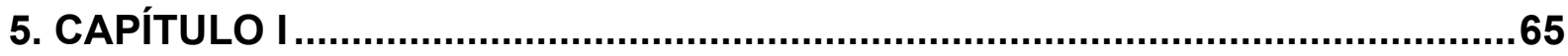

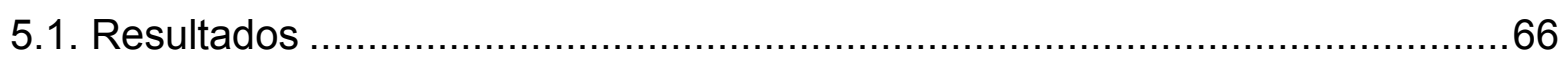

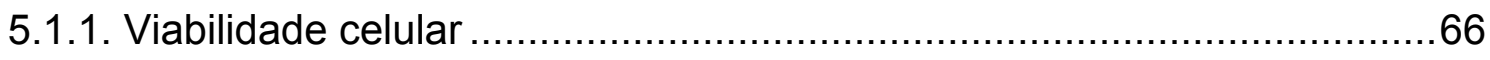

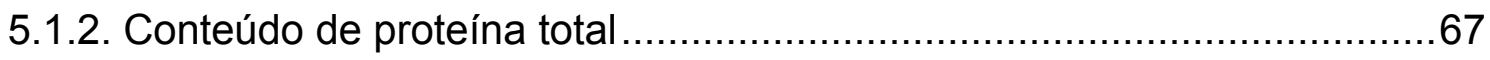

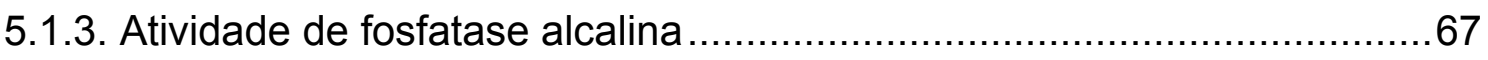


5.1.4. Localização de proteínas da matriz extracelular não-colágena por imunofluorescência indireta.

5.1.5. Expressão quantitativa dos genes por reação em cadeia da polimerase em tempo real (Real-time PCR) ........................................ 71

5.1.5.1. Expressão de RNAm de marcadores do fenótipo fibroblástico......71

5.1.5.2. Expressão de RNAm de marcadores do fenótipo osteoblástico....73

5.1.6. Formação de matriz mineralizada ............................................. 76

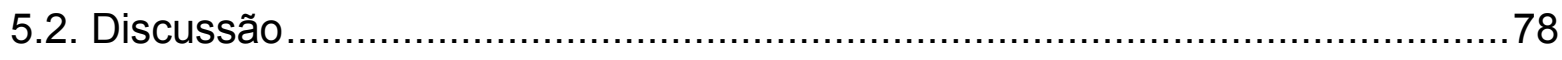

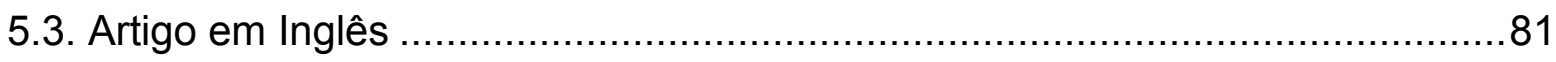

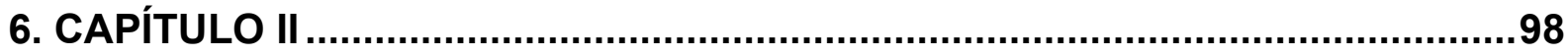

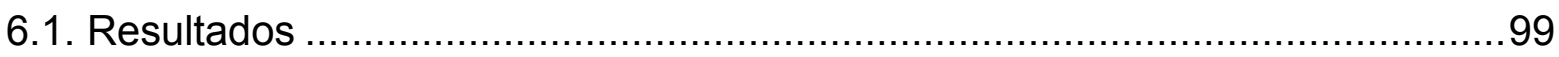

6.1.1. Conteúdo de proteína total ..................................................99

6.1.2. Atividade de fosfatase alcalina ................................................ 100

6.1.3. Localização de proteínas da matriz extracelular não-colágena por imunofluorescência indireta.......................................................... 101

6.1.4. Expressão quantitativa dos genes por reação em cadeia da polimerase em tempo real (Real-time PCR) .......................................... 103

6.1.5. Formação de Matriz mineralizada ................................................ 105

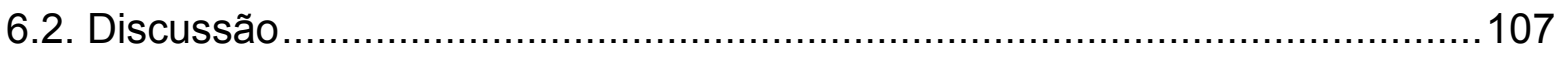

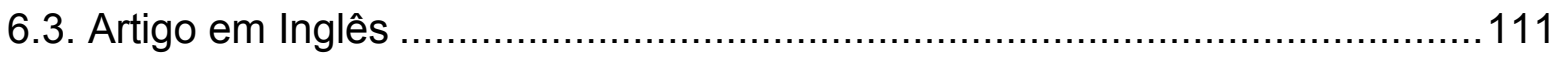

7. CONCLUSÕES DA TESE................................................................. 129

REFERÊNCIAS BIBLIOGRÁFICAS .........................................................131

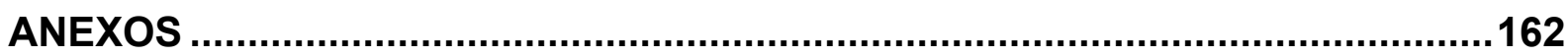


1. Introdução 
A engenharia tecidual tem sido definida como a aplicação de princípios e técnicas das ciências biológicas e da engenharia para a construção e o crescimento de tecidos vivos utilizando biomateriais, células em cultura e fatores de crescimento, isoladamente ou em combinação (Langer; Vacanti, 1993; Sittinger et al., 1996; Griffith; Naughton, 2002). Para reconstituir o ambiente in vivo, células devem aderir e crescer adequadamente nos arcabouços tridimensionais (3D), facilitando assim o contato célula-célula e a expressão do fenótipo esperado (Hoffman, 1993; Minuth et al., 1998; Griffith, 2000).

Com os avanços das pesquisas baseadas na engenharia tecidual, a busca por novas terapias para reconstrução do periodonto destruído pela doença periodontal, tem alcançado novas perspectivas. A capacidade regeneradora das células do ligamento periodontal (PDL) foi inicialmente proposta quando se observou que estas células eram capazes de se diferenciarem em fibroblastos, cementoblastos e osteoblastos (Melcher, 1976). A partir de então, tem-se atribuído fundamental importância ao ligamento periodontal no processo de reparo e regeneração do periodonto (Ivanovski et al., 2006).

As células osteoprogenitoras combinadas aos biomateriais também têm demonstrado seu potencial para o reparo e regeneração do tecido ósseo (Anselme et al., 1999). Modelos de cultura de células são rotineiramente utilizados para estudos de eventos osteogênicos e da resposta celular em contato com biomateriais (Puleo; Nanci, 1999). Esses sistemas in vitro proporcionam a oportunidade de se observarem, em ambiente controlado, os complexos eventos celulares e da matriz extracelular (MEC), associados ao processo de formação óssea (Nanci et al., 1996; Irie et al., 1998; Nanci et al., 1998; De Oliveira et al., 2003).

Dentre os biomateriais utilizados para o reparo e regeneração de defeitos ósseos periodontais, os vidros bioativos (VB) representam materiais sintéticos promissores, por serem biocompatíveis e apresentarem propriedades osseocondutoras (Furusawa; Mizunuma, 1997). Estudos in vitro têm demonstrado a influência positiva do vidro bioativo em culturas de células osteoblásticas (Matsuda; Davies 1987), sua capacidade em inibir a proliferação fibroblástica (Matsuda et al., 1987) e de formar focos de calcificação em culturas de fibroblastos do ligamento periodontal (Hench; Paschall, 1974).

Embora as células do ligamento periodontal se assemelhem a um tipo de célula terminalmente diferenciada ou um estado de maturação intermediária que 
potencialmente pode ser direcionada para um fenótipo fibroblástico ou osteoblástico; e que os sistemas de cultura de células osteogênicas estejam bem documentados e suportem o fenótipo celular osteogênico (Ishaug et al., 1997; Trojani et al., 2005; Yefang et al., 2007; Boukhechba et al., 2009), pouco é conhecido sobre as caracteríscas fenotípicas dessas células quando semeadas em matrizes tridimensionais colágenas e/ou com partículas de vidro biativo. Portanto, o objetivo deste estudo obter uma melhor compreensão das características fenotípicas destas células, através de um modelo in vitro mais próximo da realidade encontrada in vivo nos procedimentos de regeneração periodontal. 
2. Revisão de Literatura 


\subsection{Bioengenharia}

As células que residem, proliferam e se diferenciam no organismo vivo estão dispostas em um micro ambiente tridimensional (3D) conhecido como matriz extracelular (MEC). Esta matriz é uma estrutura complexa, formada a partir de componentes sintetizados e depositados no exterior da superfície celular - colágenos glicoproteínas e proteoglicanas - os quais fornecem a integridade estrutural e funcional para os tecidos conjuntivos e órgãos. A síntese e deposição da MEC em grande parte ocorrem em resposta aos fatores de crescimento, citocinas, e sinais mecânicos mediados através de receptores da superfície celular (Daley et al., 2008; Chen; Jin, 2010).

A fim de simular esse micro ambiente e criar condições ideais para o reparo e a substituição de tecidos lesados, a bioengenharia ou engenharia tecidual surge como uma área recente de pesquisa multidisciplinar, definida como a aplicação de técnicas in vitro para desenvolver substitutos biológicos que restaurem, mantenham ou melhorem a função de diferentes tecidos vivos a partir dos princípios da biologia celular utilizando biomateriais (Vacanti et al., 1991; Nerem; Sambanis, 1995; Kaigler; Mooney, 2001; Rosso et al., 2004).

O sucesso da engenharia tecidual depende da interação entre três componentes importantes: fonte celular que irá criar o novo tecido, o biomaterial que atua como uma matriz extracelular sintética, ou seja, um arcabouço para as células, além dos fatores de indução para o crescimento celular, tais como moléculas biológicas sinalizadoras que induzem as células a formarem o tipo de tecido desejado (Lavik; Langer, 2004; Bartold et al., 2006).

As células são isoladas a partir de amostras ou biópsias de tecidos e expandidas in vitro, crescem normalmente nestas matrizes sintéticas 3D in vitro, as quais permitem a interação célula-célula e célula-matriz, o que contribui para a formação e o desenvolvimento de novos tecidos (Bartold et al., 2006). Estas interações devem ser devidamente reguladas durante o processo de desenvolvimento dos tecidos, a fim de induzir o padrão requerido de expressão gênica. Além dessas interações, a expressão de genes por células em tecidos artificiais pode ser regulada por fatores de crescimento solúveis e estímulos mecânicos sobre as células (Kim; Mooney, 1998).

Os fatores de indução para o crescimento celular são proteínas solúveis que atuam na proliferação celular, síntese de matriz e diferenciação e morfogênese de 
tecidos e órgãos. Eles podem agir como mitogênicos (aumento da proliferação de determinados tipos celulares) ou morfogênicos (alteração do fenótipo de célulasalvo). Entre os disponíveis, sugere-se que os fatores de crescimento derivados das plaquetas (PDGF), similares à insulina (IGFs), transformação-ß (TGF-ß) e proteínas ósseas morfogenéticas (BMPs), estão associados fortemente com o reparo ósseo (Schilephake, 2002; Hughes et al., 2006; Ripamonti; Renton, 2008).

As matrizes tridimensionais sintéticas ou arcabouços simulam in vitro a matriz extracelular (MEC) natural com a qual as células interagem in vivo (Lee et al., 2008). Apresentam um papel importante na engenharia tecidual, pois servem de substrato para que as células tenham suporte estrutural para guiar a formação de novos tecidos. Para sua confecção são necessários materiais que sejam biocompatíveis e biodegradáveis, permitindo a substituição gradual por tecido regenerado (Kim; Mooney,1998); devem estar livres de doenças transmissíveis, imunologicamente inertes, e não induzir uma resposta inflamatória exuberante (Omstead et al., 1998); e devem apresentar características ambientais que induzam a expressão gênica requerida para a reconstrução tecidual, pois funções e fenótipos celulares também são regulados pelo microambiente de residência das células em questão (Srisuwan et al., 2006; Bartold et al., 2008).

Esses arcbouços apresentam-se como esponjas, géis ou membranas, que podem ser reabsorvíveis ou não absorvíveis, e são fabricados a partir de produtos sintéticos - poliésteres hidroliticamente degradáveis, tais como ácido poliglicólico (PGA), ácido glicólico lático ou polilático (PLGA), hidroxiapatita (HA) e fosfato tricálcio $\left[\mathrm{Ca}_{3}\left(\mathrm{PO}_{4}\right)_{2}\right](\mathrm{TCP})$ - ou naturais - ácido hialurônico, alginato, colágeno (Rutherford et al., 1993; Blumenthal et al., 2002; Nakahara et al., 2003; Sato et al., 2004; Yang; El Haj, 2006; Hall, 2007; Mimori et al., 2007; Tessmar; Gopferich, 2007; Agarwal; Mallapragada, 2008).

Uma vez que o osso é principalmente uma combinação de compostos orgânicos e inorgânicos, ou seja, cristais de hidroxiapatita (HA) dentro de uma rede de colágeno da matriz extracelular, os estudos tentaram recriar a sua estrutura por meio de aracabouços preparados a partir de uma combinação de polímeros e materiais cerâmicos, com base nessa estrutura (Balooch et al., 2008; Lode et al., 2008).

A geração de arcabouços que se assemelham a natureza da matriz óssea com base em colágeno e HA deve oferecer uma plataforma útil para avaliar as culturas de células osteogênicas. Arcabouços compostos de vidro bioativo (VB) têm sido 
desenvolvidos e testados in vitro para engenharia de tecido ósseo (Mastrogiacomo et al., 2001; Uemura et al., 2003; Marcacci et al., 2007). Embora não seja difícil de obter osso a partir de biocerâmicas compostas implantadas com células osteogênicas (Yoshikawa et al., 1996; Muraglia et al., 1998; Lee et al., 2001b; Quarto et al., 2001; Dong et al., 2002), o desenvolvimento de modelos ósseos tridimensionais in vitro através de arcabouços compostos permanece um desafio importante a ser superado.

\subsection{Colágeno}

O colágeno é a proteína mais abundante no organismo, representa cerca de 20$30 \%$ das proteínas totais do corpo (Harkness, 1961). É sintetizado pelos fibroblastos, que normalmente se originam de células pluripotenciais ou células do retículo (Lee et al., 2001a), e digerido por colagenases e metaloproteases da matriz (Hubbell, 2003), o que pode ser tanto uma vantagem ou uma desvantagem, dependendo da aplicação (Schindler et al., 2006).

O colágeno tem sido um dos arcabouços mais utilizado na engenharia tecidual (Lee et al., 2001a; Drury; Mooney, 2003) devido à sua excelente biocompatibilidade e segurança associada às suas características biológicas, tais como biodegradabilidade e fraca antigenicidade. Trata-se de uma proteína bem conhecida, que tem sido amplamente utilizada em aplicações médicas, uma vez que o colágeno desempenha um papel importante na formação de tecidos e órgãos, e está envolvido em várias expressões funcionais das células (Fonseca et al., 1996).

Muitos estudos sobre comportamento celular em matrizes colágenas mostram que esta proteína influencia na morfologia, migração, adesão e diferenciação celular (Chevallay; Herbage, 2000). Além disso, substratos colágenos são capazes de alterar o perfil de progressão do fenótipo celular (Lynch et al., 1995). Portanto, arcabouços de colágeno tridimensionais têm sido utilizados para produzir fenótipos mais diferenciados (Jacquot et al., 1994).

Cultura de células dentro de tais matrizes tridimensionais não é uma idéia nova. Um sistema modelo foi descrito para as células fibroblásticas no corpo usando matrizes de colágeno polimerizadas in vitro para formar uma rede fibrosa tridimensional. Este colágeno tridimensional gelificado induziu alterações morfológicas nos fibroblastos que parcialmente imitavam células do tecido conjuntivo in vivo (Elsdale; Bard, 1972). Desde então, géis de colágeno têm sido amplamente 
utilizados para estudar a motilidade celular (Friedl; Brocker, 2000) e o papel do estado físico de géis tridimensionais (Grinnell, 2000).

Além disso, os géis de colágeno são capazes de tomar qualquer forma desejada e, portanto, se adaptar a qualquer tamanho do defeito. Em contraste com outros tipos de biomateriais, onde as células normalmente só podem ser semeadas sobre a superfície do arcabouço, os géis de colágeno mostram uma distribuição celular uniforme, o que permite a síntese homogênea de componentes da matriz extracelular (Nöth et al., 2006). O problema principal dos géis de colágeno é a contração, que é principalmente dependente da densidade e proliferação celular dentro do gel, concentração de colágeno, dos fatores de crescimento, bem como o número e comprimento de fibras (Steinberg et al., 1980; Schmitt et al. , 2003; Lewus; Nauman, 2005; Yokoyama et al., 2005).

Esponjas de colágeno e membranas também oferecem características particulares para a integração de células no reparo ou formação dos tecidos. As células podem ser cultivadas e prontamente semeadas nesses materiais e depois introduzidas num local do defeito do tecido, onde podem efetuar reparação e regeneração. Apresentam uma boa resistência mecânica podendo proteger as células de perturbações ambientais. Além disso, as matrizes colágenas podem simular melhor as condições fisiológicas tridimensionais in vivo. Deste modo, o colágeno vem sendo utilizado para fins de engenharia de tecidos, incluindo a substituição da pele, substitutos de osso, vasos sanguíneos artificiais, válvulas (Xiao et al., 2003), bem como no processo de cicatrização, suporte e regeneração tecidual guiada em periodontia (Chung et al., 1990; Sisken et al., 1993).

\subsection{Vidro Bioativo}

Desenvolvidos na década de 70 (Hench et al., 1972), os vidros bioativos (VB) são cerâmicas à base de sílica na superfície ativa $\left(\mathrm{SiO}_{2}, \mathrm{CaO}, \mathrm{Na}_{2} \mathrm{O}\right.$ e $\left.\mathrm{P}_{2} \mathrm{O}_{5}\right)$ e são utilizados como um material de enxerto ósseo para o prenchimento e reconstrução dos defeitos ósseos e periodontais (Wilson; Low, 1992; Deforge, 1997; Wheeler et al., 1997). Eles são semelhantes aos substitutos ósseos, tais como hidroxiapatita (HA) e fosfato tricálcico (TCP), que são altamente biocompatíveis, e também possuem propriedades osteocondutoras (Homaeigohar et al., 2005; Carinci et al., 2007; Moura et al., 2007; Sun et al., 2007). 
Materiais bioativos foram definidos com base em uma resposta biológica específica provocada quando implantado no tecido. Este conceito é baseado no controle da química de superfície do material. Reações que ocorrem na superfície de vidros bioativos levam à formação de uma camada de gel de sílica e a cristalização subsequente da apatia hidroxicarbonada (HCA) (Clark et al., 1976; Ogino et al., 1980), que atrai células osteoprogenitoras e osteoblastos, estimula a proliferação e diferenciação dessas células e auxilia na integração ao tecido do hospedeiro, estimulando assim a formação óssea. Adicionalmente, os materiais bioativos são capazes de liberar produtos iônicos que podem afetar as respostas celulares, pois criam um ambiente favorável para a proliferação dos osteoblastos e diferenciação in vivo.

Uma propriedade importante dos vidros bioativos é a liberação de sílica (Si) solúvel, que quando expostos aos fluidos biológicos tem-se como resultado uma permuta iônica com $\mathrm{H}+$ que leva à alcalinização externa, o que pode influenciar profundamente o metabolismo e função celular (Busa; Nuccitelli, 1984). Esta alcalinização do meio aumenta o metabolismo das células osteoblásticas, enquanto esses efeitos metabólicos são menores em fibroblastos (Silver et al., 2001). Além disso, a liberação controlada de Ca e Si solúveis a partir de compostos poliméricos de vidro bioativo reabsorvível leva a regeneração dos tecidos moles vascularizados (Hench et al., 2004).

Uma das vantagens dos vidros bioativos é a sua utilização como matriz para o crescimento de tecido in vitro (Ducheyne et al., 1994; El-Ghannam et al., 1995; Loty et al., 2001). Esses materiais parecem preencher a maioria dos critérios exigidos como um arcabouço adequado para suportar o crescimento do tecido ósseo.

Vários estudos in vitro têm demonstrado a não toxicidade do vidro bioativo e a sua influência na proliferação e diferenciação de osteoblastos (Matsuda; Davies 1987; Vrouwenvelder et al., 1992; El-Ghannam et al., 1997a; b; Price et al., 1997), a capacidade inibitória sobre a proliferação de fibroblastos (Matsuda et al., 1987) e a indução de focos de calcificação nos fibroblastos do ligamento periodontal (Hench; Paschall, 1974).

Considerando que os vidros bioativos são utilizados em defeitos ósseos periodontais (Wilson; Low, 1992), tem sido analisado o efeito desses materiais na diferenciação dos fibroblastos do ligamento periodontal humano (hPDLF) (Varanasi et al., 2011), uma vez que os produtos iônicos liberados pelos vidros bioativos 
aumentam a expressão de marcadores osteogênicos (por exemplo, colágeno I, fosfatase alcalina e osteocalcina) importantes para a diferenciação celular (Xynos et al., 2001; Foppiano et al., 2007; Varanasi et al., 2009).

Estudos mostraram que embora a proliferação celular tenha diminuído na presença do vidro bioativo e vitamina D3, a atividade de fosfatase alcalina e formação de nódulos mineralizados em culturas de fibroblastos do ligamento periodontal aumentaram (Kubo et al., 1993). Além disso, altas concentrações de cálcio e de silício liberadas a partir do vidro bioativo foram detectados no meio de cultura (Kubo et al., 1995), o que diz respeito à formação de nódulos sobre as células do ligamento periodontal (Kubo et al., 1997).

O vidro bioativo promove o crescimento e a maturação de osteoblastos de rato (Effah Kaufmann et al., 2000) e humano (Bosetti et al., 2003), além da expressão e manutenção do fenótipo osteoblástico, sugerindo que existe tanto os eventos de superfície bem como os efeitos mediados por solução sobre atividade de células estromais de medula óssea de ratos in vitro (Radin et al., 2005). Além disso, evidências de estudos animais sugerem que eles também podem aumentar a formação óssea em sítios de implantação in vivo (Oonishi et al., 1997).

Células osteoblásticas MC3T3-E1 cultivadas em discos contendo sílica $45 \%$ apresentaram maior capacidade proliferativa, mas mostraram expressão limitada do fenótipo osteoblástico quando comparado com discos de hidroxiapatita sem sílica (El-Ghannam et al., 1997b).

Tem sido relatado que a formação de nódulos ósseos ocorre quando células derivadas de osso humano são cultivadas durante longos períodos de tempo na presença de ácido ascórbico e/ou $\beta$-glicerofosfato, porém a formação de nódulos ósseos calcificados pode ser detectada na cultura sobre o vidro bioativo, sem qualquer um dos suplementos osteoindutores no meio de cultura (Beresford et al., 1993).

A adição de grânulos de vidro bioativo também pode servir para reforçar e endurecer a matriz polimérica para produzir um substrato composto bioativo e biodegradável. Diferenças significativas foram observadas na síntese de colágeno tipo I e na mineralização de células osteoblásticas entre a matriz polimérica composta e as superfícies controles de poliestireno (Lu et al., 2003).

As formulações disponíveis de vidro bioativo variam em forma, composição e tamanho (Pereira et al., 1994; El-Ghannam et al., 1997a). O Biogran ${ }^{\text {TM }}$ (Orthovita, Implant Innovations, Palm Beach Gardens, Flórida, EUA) é um vidro bioativo amorfo reabsorvível 
de partículas com tamanho de aproximadamente 300-355 mm de diâmetro (Tadjoedin et al., 2000). Ele é composto de dióxido de silícia $45 \%\left(\mathrm{SiO}_{2}\right)$, óxido de cálcio $24,5 \%(\mathrm{CaO})$, óxido de sódio 24,5\% ( $\mathrm{NaO} 2$ ), e pentóxido de fósforo 6\% $\left(\mathrm{P}_{2} \mathrm{O}_{5}\right)$. Tem sido demostrado sua influência positiva na reparação óssea, não só pelas propriedades osteocondutoras das partículas, mas também pelo seu potencial osteostimulatório definido como a formação de osso dentro de defeitos periodontais com as partículas biovidro longe das pré-existentes paredes do defeito ósseo (Schepers; Ducheyne, 1997). Este material parece reabsorver por dissolução e não de pela atividade osteoclástica (Furusawa e Mizunuma 1997; Schepers e Ducheyne 1997; Tadjoedin et al. 2000; Al Ruhaimi 2001).

Com efeito, estudos clínicos e histológicos indicaram resultados satisfatórios com o uso desse material no tratamento de defeitos periodontais infraósseos e de bifurcação (Fetner et al., 1994; Froum et al., 1998; Karatzas et al., 1999; Mengel et al., 2003; Villaca et al., 2005). Apesar disso, as partículas de vidro bioativo não interagem apenas com a matriz óssea, mas também com componentes de matriz não mineralizada. Alterações importantes foram observadas nos aspectos estruturais da medula óssea com a presença de partículas de vidro bioativo, com o aumento expressivo de feixes de fibras colágenas e redução da celularidade, indicando um possível efeito sobre a atividade de células fibroblásticas (Roriz et al., 2010).

Os mecanismos celulares que conduzem à exposição de vidros bioativos para reparação tecidual ainda não são completamente entendidos (Sun et al., 2007), porém essas descobertas têm potenciais implicações para a engenharia tecidual, onde substratos de vidro bioativos poderiam ser usados como suporte e/ou estímulo para a formação de tecido ósseo in vitro.

\subsection{Cultura tridimensional}

A maioria dos estudos com cultura de células é executada em superfícies bidimensionais (2D), tais como micro-poços, frascos de cultura de tecidos, e placas de Petri devido à facilidade, conveniência e viabilidade celular dessas culturas. Esses sistemas de culturas em monocamada convencionais notavelmente têm melhorado a compreensão da biologia celular, mas as desvantagens residem na utilização de substratos planos que impõem restrições geométricas e mecânicas em muitos tipos de células (Bokhari et al., 2007). No organismo, quase todas as células residem em uma matriz extracelular (MEC) constituída por uma malha fibrosa, complexa e tridimensional com uma ampla distribuição de fibras e lacunas que 
fornecem sinais bioquímicos e físicos (Lee et al., 2008). Tem sido mostrado que o crescimento e função das células como estruturas 3D multi-celulares são significativamente diferentes do seu crescimento em culturas convencionais $2 \mathrm{D}$ (Cukierman et al., 2001; Schmeichel; Bissell, 2003; Beningo et al., 2004; Witte; Kao, 2005). Várias tentativas têm sido feitas no sentido de estabelecer um sistema de cultura in vitro que mimetize as interações entre células e MEC, como ocorre in vivo (Mauch et al., 1988).

As culturas $3 \mathrm{D}$ foram definidas como "células isoladas e expandidas que aderem aos arcabouços, proliferam e secretam componentes da MEC, posteriormente substituindo os scaffolds e reconstruindo os tecidos" (Mcculloch, 1985). Existem muitas diferenças dessas culturas quando comparadas com as culturas em monocamada convencionais in vitro (Giannobile, 1996).

Fibroblastos cultivados em géis de colágeno 3D experimentam um ambiente mais rico, complexo, física e geometricamente muito diferente do que células em superfícies 2D. Estruturalmente apresentam uma morfologia característica mais alongada como in vivo. Porém, quando cultivados em monocamada, tendem a espalhar sobre um substrato $2 \mathrm{D}$, adquirem uma parte superior (dorsal) e superfície inferior (ventral), aderências de células proeminentes seguindo a forma do substrato sobre a superfície ventral e crescem até a confluência com uma taxa de proliferação elevada. Quando colocados de volta em uma matriz 3D os fibroblastos perdem essa polaridade dorso-ventral artificial e recuperam a sua morfologia in vivo (Cukierman et al., 2001; Grinnell, 2003; Amatangelo et al., 2005). Além disso, os fibroblastos do ligamento periodontal, quando em culturas tridimensionais, apresentam maior expressão de osteopontina (OPN) e osteocalcina (OC) quando comparados com as mesmas células crescidas sobre substratos bidimensionais (Inanc et al., 2006).

Funcionalmente, essas células demonstraram um aumento 2 vezes maior na taxa de proliferação e 1,5 na taxa de migração em comparação com as células cultivadas em superfícies de cultura 2D revestidas com laminina-1 ou colágeno IV (Cukierman et al., 2001). Também tem sido demonstrado que a síntese de colágeno pelos fibroblastos em culturas $2 \mathrm{D}$ é muito maior do que em uma matriz de colágeno 3D (Nusgens et al., 1984; Mauch et al., 1988), o que pode ser resultado da distribuição tridimensional de fibras de colágeno em torno das células que induz uma inativação mitótica (Nishiyama et al., 1989; Kono et al., 1990) por um confinamento bioquímico (Nakagawa et al., 1989b; a). As moléculas sintetizadas e secretadas por 
fibroblastos são aprisionadas pela rede de colágeno do gel, inibindo a produção de colágeno (Doillon et al., 1987; Thie et al., 1989). Além disso, como resultado das interações entre os fibroblastos e o gel colágeno, essas células agem contraindo a matriz através da ação de integrinas (Elsdale; Bard, 1972; Bell et al., 1979; Grinnell, 1994). Numerosos estudos têm mostrado contração do gel de colágeno pelos fibroblastos (Beertsen et al., 1974; Bellows et al., 1981; Pender; Mcculloch, 1991).

Alguns estudos sobre o efeito das culturas 3D na diferenciação dos osteoblastos utilizando linhagens osteogênicas estabelecidas (Botchwey et al., 2001; Rucci et al., 2002) têm demonstrado o aumento da agregação celular, da diferenciação e mineralização dos osteoblastos (Facer et al., 2005; Ko et al., 2007; Boehrs et al., 2008). Além disso, também foi observado que os genes osteogênicos, tais como RUNX2, relacionado com a diferenciação de osteoblastos e mineralização foram geralmente expressos em níveis mais elevados nas células cultivadas em ambientes 3D, em comparação com aquelas em 2D (Botchwey et al., 2001; Rucci et al., 2002) No que diz respeito à morfologia, as células crescidas em cultura 3D, desenvolvem uma morfologia comum, com forma estrelada e projeções citoplasmáticas; muito semelhantes aos osteócitos in vivo. Apesar das diferenças na morfologia entre osteoblastos e osteócitos em cultura 2D, osteoblastos em 3D cultura poderiam formar processos dendríticas semelhantes às dos osteócitos (Vukicevic et al., 1990; Karsdal et al., 2002; Kurata et al., 2006).

A tridimensionalidade por si só, independente da composição da matriz, pode fisiologicamente reprogramar as células. Existem diferenças notáveis na morfologia, proliferação e sentido de migração entre as células cultivadas sobre uma matriz 3D versus células cultivadas em uma matriz de composição bioquímica idêntica que foi achatada para proporcionar uma superfície 2D (Cukierman et al., 2001; Pankov et al., 2005; Zaman et al., 2006). Células cultivadas em géis de colágeno I e em superfícies $2 \mathrm{D}$ revestidas com colágeno I exibem padrões distintos de sinalização e migração (Cukierman et al., 2002; Beningo et al., 2004; Wozniak et al., 2004; EvenRam; Yamada, 2005) e demonstraram capacidade de expressarem fenótipos e funções diferenciadas (Grinnell, 2003; Wozniak et al., 2003).

As células cultivadas em matrizes 3D representam mais de perto a estrutura natural e função dos tecidos in vivo no que diz respeito à fisiologia, forma da célula e seu ambiente, aspectos tais que desempenham um papel importante em muitos processos biológicos, tais como motilidade, crescimento, metabolismo, 
desenvolvimento, diferenciação e expressão gênica (Mueller-Klieser, 1997; Chevallay; Herbage, 2000; Xu et al., 2009).

\subsection{Fibroblastos do ligamento periodontal}

Periodontite é uma doença inflamatória que destrói gengiva, ligamento periodontal, cemento, e o osso alveolar. Afeta cerca de $10 \%$ da população adulta e leva a reabsorção óssea e, finalmente, a perda do dente (Schroder et al., 2005). O objetivo final da terapia periodontal é reparar os tecidos de suporte periodontais danificados como resultado do processo da doença periodontal, regenerando o periodonto de proteção e sustentação (Wang et al., 1994).

Numerosos estudos têm sido realizados para melhorar procedimentos clínicos regenerativos na terapia periodontal. Recentemente, pesquisadores têm se concentrado na regeneração periodontal utilizando a engenharia de tecidos (Murphy; Mooney, 1999; Nakahara et al., 2004). Este processo presumivelmente envolve vários tipos de células: fibroblastos, cementoblastos, osteoblastos e células endoteliais (Pitaru et al., 1994). No entanto, as células derivadas do ligamento periodontal são as mais frequentemente investigadas em estudos atuais porque fibroblastos do ligamento periodontal humano são conhecidos por desempenhar um papel chave na regeneração do periodonto durante procedimentos de regeneração tecidual guiada (RTG) (Berkovitz, 2004).

A identificação de células mesenquimais no ligamento periodontal (Seo et al., 2004) juntamente com melhor conhecimento do fenótipo periodontal regenerativo dessas células (Ivanovski et al., 2001) podem propiciar o isolamento, cultivo e subsequentemente incorporação dessas células em um arcabouço biodegradável adequado para introdução imediata em um defeito periodontal (Bartold et al., 2000).

Explantes do ligamento periodontal originam colônias fibroblásticas com um grau de hetereogeneidade em suas características morfológicas, potencial de diferenciação e capacidade proliferativa. Isto indica que nessa população há uma mistura de células progenitoras em várias fases de desenvolvimento, que são provavelmente mantidas por uma população minoritária de células tronco mesenquimais com a capacidade de auto-renovação, tal como anteriormente descrito para o sistema de células tronco estromais da medula óssea (Owen et al., 1987). 
Enquanto uma grande porcentagem de células em culturas de PDL é susceptível a serem fibroblastos determinados (Lekic; Mcculloch, 1996; Lekic et al., 1997) uma proporção substancial das células mostram uma resposta osteogênica à estimulação adequada (Piche et al., 1989; Ogata et al., 1995; Basdra; Komposch, 1997; Liu et al., 1997; Nohutcu et al., 1997; Chien et al., 1999; Kuru et al., 1999). Os estudos in vivo mostraram que as células do o ligamento periodontal passam por um processo de maturação a partir de células precursoras fibroblásticas para células osteoprogenitoras, (Roberts; Jee, 1974; Gould et al., 1980; Roberts; Morey, 1985; Roberts et al., 1987), ou seja, se desenvolvem em células formadoras de osso, osteoblastos (Mcculloch; Melcher, 1983b; a).

In vitro, o potencial osteogênico de células é caracterizado por, entre outros, a síntese de colágeno I (Flores et al., 2008), atividade de fosfatase alcalina (ALP) e expressão de marcadores ósseos (Isaka et al., 2001; Nakahara et al., 2004). Além disso, as células do ligamento periodontal têm a capacidade de formar nódulos mineralizados in vitro, sob condições de cultura adequadas para osteodiferenciação (Arceo et al., 1991; Cho et al., 1992; D'errico et al., 1999; Somerman et al., 1999; Seo et al., 2004).

Estudos têm demonstrado que as células do ligamento periodontal exibem atividade de ALP (Piche et al., 1989), e esta atividade é mais elevada quando comparado com fibroblastos gengivais (Somerman et al., 1988; Murakami et al., 2003).

A expressão de marcadores ósseos tais como fosfatase alcalina (ALP), osteopontina (OPN), sialoproteína óssea (BSP) osteocalcina (OC) e RUNX2 também tem sido demonstrada em culturas 2D e 3D (Inanc et al., 2006) de fibroblastos ligamento periodontal humano com meios de diferenciação osteogênica contendo ácido ascórbico, $\beta$-glicerofosfato, e dexametasona (Arceo et al., 1991; Nohutcu et al., 1996; Carnes et al., 1997; Ivanovski et al., 2001; Lekic et al., 2001; Haase et al., 2003; Murakami et al., 2003; Kao et al., 2005; Inanc et al., 2006).

A fosfatase alcalina (ALP) é uma enzima intimamente associada com o processo de mineralização. Tem sido sugerido que a hidrólise de ésteres de monofosfato pela enzima produz uma alta concentração de fosfatos (Beertsen; Van Den Bos, 1989), conduzindo a sobressaturação e subsequente precipitação de sais de fosfato de cálcio no substrato colagenoso (Robison, 1923). A ALP é uma glicoproteína que 
está envolvida na formação de minerais nos tecidos calcificados (Woltgens et al., 1982; Beertsen;Van Den Bos, 1989; 1991).

A osteoopontina (OPN), um marcador de início da formação óssea, está envolvida na proliferação e migração de populações de células osteogênicas e cementogênicas. Essa proteína é expressa em dois estágios de osteogênese: numa fase precoce proliferativa e numa fase posterior, após a formação inicial de osso mineralizado. Em culturas de fibroblastos do ligamento periodontal foi encontrada para correlacionar com potencial de diferenciação osteogênica (Haase et al., 2003) e síntese de tecido mineralizado (Lekic et al., 1996).

A osteocalcina (OC) é uma das proteínas da matriz extracelular do osso que tem um papel na calcificação (Boskey, 1996). Parece ser um marcador 'tardio' durante a diferenciação dos osteoblastos, característica de osteoblastos maduros. Não tem sido descrita como uma característica normal de fibroblastos do ligamento periodontal. Autores demonstraram que apesar de osteocalcina está presente em células ósseas, esta molécula não pode ser detetada em fibroblastos do ligamento periodontal de ratos (Bronckers et al., 1994).

A Sialoproteína óssea (BSP) é uma proteína característica de osteoblastos diferenciados, sendo fortemente detectada nessas células. Em culturas de células, a BSP não é sintetizada até que as células tenham nódulos de tecido mineralizados ativos e de múltiplas camadas (Kasugai et al., 1992).

Uma vez que a OPN, BSP e OC podem desempenhar papéis importantes na diferenciação de osteoblastos e mineralização óssea (Boskey, 1996), a expressão significativamente mais forte destas três macromoléculas fornece uma evidência adicional do potencial de formação de tecido duro dentro de uma subpopulação das células que residem dentro do ligamento periodontal (Somerman et al., 1991).

O colágeno do tipo I (COL I) constitui a parte principal da matriz extracelular osteogênica que será mineralizada na última fase da formação óssea. A interação entre o $\mathrm{COL} I$ e as células através de integrinas regula muitas funções celulares, tais como aumento da proliferação, uma indução de diferenciação e apoptose (Giancotti;Ruoslahti, 1999; Hynes, 2002). Fibroblastos do ligamento periodontal também predominantemente secretam COL I, formando fibras do ligamento periodontal. Como tal, esta proteína não pode ser designada como um marcador de osso específico (Inanc et al., 2006). O estabelecimento da matriz de colágeno I é importante na diferenciação de células osteoblástica do ligamento periodontal (Ishikawa et al., 2004). 
O RUNX2 é um gene essencial para a diferenciação osteoblástica e ativa e/ou reprime outros genes envolvidos na formação do tecido ósseo (Ducy et al., 1997; Kern et al., 2001). Embora outros genes estejam ativos antes para RUNX2 na cascata de osteogênese, RUNX2 é bem caracterizado no processo de osteogênese (Neeley et al., 2010).

A S100A4, um membro da família de proteínas de ligação de cálcio S100, é sintetizada e segregada pelas células do ligamento periodontal, e pode atuar como um inibidor da diferenciação dos osteoblastos e de mineralização (Duarte et al., 1999; Kato et al., 2005; Taba et al., 2005).

A periostina (PRT), que foi originalmente isolada a partir de linhagens celulares de osteoblastos (por exemplo, MC3T3E1), desempenha um papel específico na formação de tecido mineralizado (Horiuchi et al., 1999). É preferencialmente expressa no ligamento periodontal e periósteo, indicando a sua especificidade tecidual e papel na formação de ossos e dentes e manutenção da estrutura. Portanto, S100A4 e PRT podem participar na regeneração e/ou diferenciação de células do ligamento periodontal, para os quais eles podem ser utilizados como marcadores específicos (Pi et al., 2007).

Esses achados são consistentes com as observações de outros estudos em que um potencial ósseo também foi demonstrado numa população de células gengivais onde alterações morfológicas de fusiforme fibroblástica para redonda em forma de células osteoblásticas foram observadas em culturas com suplemento osteogênico, além da positividade para a coloração com vermelho de Alizarina, tanto da matriz extracelular quanto das células. (Ivanovski et al., 2001; Haase et al., 2003). Vermelho de Alizarina é um corante, que se liga especificamente a cristais minerais, indicando mineralização em culturas de célula (Haase et al., 2003).

Os níveis de expressão de genes osteogênicos, tais como OC, OPN e BSP, em células do ligamento periodontal humano em meio de cultura osteoindutor os níveis foram maximizados no $14^{\circ}$ dia de cultura, e uma área marcada positivamente com vermelho de Alizarina foi observada no mesmo tempo. No entanto, os níveis de expressão de todos os três genes foram diminuídos no período de 21 dias. Assim, concluiu-se que o cultivo com meio osteoindutor durante 14 dias foi suficiente para aumentar a diferenciação osteoblástica de células do ligamento periodontal humano. Em seguida, foram analisados os genes marcadores de células do ligamento 
periodontal humano, S100A4 e PRT, que mostraram forte expressão em todas as células do ligamento (Iwata et al., 2010)

Contudo, outro estudo mostrou que as células do ligamento periodontal exibiam uma cultura tempo-dependente e uma diminuição da atividade proliferativa que foi acompanhada por um aumento na atividade da fosfatase alcalina e produção de OC, indicando uma mudança de um aumento inicial no número de células para posterior diferenciação para um fenótipo de osteoblastos maduros (Lossdorfer et al., 2008). Estes achados estão de acordo com os dados obtidos em células de medula óssea estromais (Huang et al., 2004), osteoblastos diferenciados (Owen et al., 1990; Thomas et al., 2001) e fibroblastos do ligamento periodontal, nos quais essas células apresentaram uma típica morfologia fusiforme, produção de OC(Nojima et al., 1990 ) e níveis elevados de ALP (Groeneveld et al., 1993) sob indução após 14 dias de cultura (Chou et al., 2002). Esta conclusão é apoiada pela detecção de quantidades significativamente maiores de fosfatase alcalina e outras moléculas associadas com a mineralização do tecido ligamento periodontal em cultura (Nohutcu et al., 1996; Lallier;Spencer, 2007).

Estes resultados indicam que os fibroblastos do ligamento periodontal humano exibem características fenotípicas in vitro consistentes com osteoblastos, sugerindo que estas células têm o potencial de se diferenciarem em osteoblastos e/ou cementoblastos (Basdra;Komposch, 1997). Entretanto, o potencial das células do ligamento periodontal para uso em engenharia dos tecidos periodontal para superar as limitações das terapias regenerativas periodontais convencionais é discutido (Benatti et al., 2007).

A maioria das caracterizações do ligamento periodontal é realizada em culturas de monocamada. No entanto, tais ambientes bidimensionais não têm a arquitetura celular tridimensional do tecido in vivo. Portanto, essas células semeadas em diferentes arcabouços podem facilitar o estudo dos padrões de crescimento e expressão protéica a fim de construir um novo tecido periodontal (Chou et al., 2002). Além disso, a capacidade das células do ligamento periodontal para manter suas distintas características fenotípicas in vitro é importante porque nos dá um sistema confiável em que podemos estudar e manipular estas células. 


\subsection{Células osteogênicas}

As células osteogênicas conhecidas também como células osteoprogenitoras ou células tronco não especializadas derivadas do mesênquima, localizam-se na camada interna do periósteo e no endósteo. Elas são as únicas células do tecido ósseo que sofrem divisão celular originando os osteoblastos. Entram em atividade no adulto para a reparação de lesões (Grabowski, 2009).

Os osteoblastos são as células responsáveis pela síntese da parte orgânica da matriz, produção de colágeno, formação de tecido osteóide e início da calcificação do mesmo, ou seja, são responsáveis pela formação do tecido ósseo. Estas células são completamente diferenciadas e não apresentam capacidade de migração e proliferação (Grabowski, 2009).

Osteoindução ocorre quando células osteogênicas devidamente estimuladas por agentes indutores (citocinas, fatores decrescimento, moléculas da matriz extracelular e interações celulares) transformam-se em pré-osteoblastos e, em seguida, em osteoblastos, iniciando o processo de osteogênese, ou seja, formação e desenvolvimento do osso A osteogênese pode ocorrer sobre uma determinada superfície ou arcabouço, sendo este processo denominado osteocondução (Centrella et al., 1987; Dunlop; Hall, 1995; Hall; Miyake, 1995; Kale et al., 2000).

Sistemas de cultura de células osteogênicas são rotineiramente utilizados para estudar os vários aspectos da formação de osso (proliferação, formação e mineralização da matriz) em um ambiente controlado (Lian;Stein, 1992). Um dos sistemas mais comumente utilizados é a cultura primária de células osteogênicas isoladas por digestão enzimática de fragmentos de calvárias de fetos de ratos ou de ratos recém-nascidos (Bellows et al., 1986; Bellows; Aubin, 1989; Stein; Lian, 1993). Os procedimentos de isolamento de células, as condições de cultura, a sequência temporal de diferenciação dos osteoblastos, e expressão de proteínas de matriz têm sido bem definido para este sistema (Stein;Lian, 1993).

A digestão enzimática sequencial é uma abordagem que tem sido amplamente aplicada para liberar células osteogênicas das calvárias de ratos recém-nascidos para cultura primária, a fim de examinar in vitro a expressão do fenótipo osteoblástico (Gerstenfeld et al., 1988; Owen et al., 1990; Nagata et al., 1991; Kasugai et al., 1992; Jamal; Aubin, 1996), as características de células osteoprogenitoras (Bellows et al., 1989; 1990; Asahina et al., 1993; Zohar et al., 
1997), e a formação e mineralização da matriz óssea (Binderman et al., 1974; Nefussi et al., 1985; Bellows et al., 1986; Bhargava et al., 1988; Nefussi et al., 1997).

$\mathrm{Na}$ cultura, seria ideal ter uma população única célula que evolui de forma síncrona ao longo do tempo. No entanto, não tem sido possível obter populações puras unicamente por digestão enzimática do osso da calvária de rato recémnascido com tripsina/colagenase, pois as células assim isoladas podem variar a partir de células-tronco e osteoprogenitoras aos osteoblastos totalmente diferenciados e osteócitos (Irie et al., 1998). Esta heterogeneidade poderia possivelmente estar relacionada com a idade dos animais e/ou com próprio procedimento para isolamento de células osteogênicas (Ibaraki et al., 1992; Nanci et al., 1996).

O processo de osteogênese pode ser caracterizado através da identificação de marcadores ósseos temporalmente regulados e utilizados para estimar o grau de diferenciação das células: RUNX2, ALP, COL I, OPN, BSP, e OC. O padrão de expressão das proteínas da matriz in vitro tem sido correlacionado com a aquisição e maturação do fenótipo osteoblástico (Owen et al., 1990; Stein; Lian, 1993; Lynch et al., 1995; Moursi et al., 1996). Para algumas destas proteínas, os níveis de expressão variam ao longo do tempo (Owen et al., 1990; Stein;Lian, 1993; Yao et al., 1994; Nefussi et al., 1997; Zohar et al., 1998).

A ALP e o COL I podem ser descritos como marcadores de formação precoce de osso e aparecem in vitro dentro de aproximadamente 2 semanas de cultura sob condições osteogênicas (Donahue et al., 2000). O aumento na atividade de ALP é um marcador do compromisso com a linhagem osteoblástica, enquanto que a diminuição posterior correlaciona com mineralização da matriz avançada e alguns fenótipos mais maduros (Aubin et al., 1995; Jaiswal et al., 1997).

A OPN é geralmente considerada como uma proteína não-colágena da matriz extracelular multifuncional envolvida na adesão e migração celular e na regulação da deposição mineral (Mckee; Nanci, 1996; Nanci, 1999; Sodek et al., 2000). É expressa pela primeira vez durante o período de proliferação celular, diminui após a fase proliferativa e, em seguida aumenta no início da mineralização, para atingir os níveis de pico durante a mineralização (Owen et al., 1990; Stein; Lian, 1993; Yao et al., 1994; Zohar et al., 1998). Expressão de BSP geralmente se inicia em osteoblastos recém-diferenciados (Ganss et al., 1999). No entanto, recentemente, tem sido relatado que progenitores iniciais expressam BSP (Liu et al., 2003). A OC é 
expressa a partir de osteoblastos maduros para osteócitos. O RUNX2 é um gene essencial para a diferenciação osteoblástica, regulando outros genes envolvidos na formação do tecido ósseo (Ducy et al., 1997; Kern et al., 2001).

Sob condições normais, células osteogênicas derivadas da calvária de ratos geram tecido ósseo como nódulos em áreas de multilcamadas de células durante a segunda semana de culturas primárias, que resultam da expansão clonal de osteoprogenitores e a sua entrada em sequência diferenciação dos osteoblastos (Bellows et al., 1986; Stein;Lian, 1993; Nanci et al., 1996). A formação óssea nodular in vitro é caracterizada por uma perda de capacidade proliferativa e uma regulação positiva de proteínas da matriz, tais como COL I, BSP, OC, e OPN (Owen et al., 1990; Ibaraki et al., 1992; Kasugai et al., 1992; Lian; Stein, 1992).

Recentemente, as vantagens das culturas 3D na indução da diferenciação de células mesenquimais para osteoblastos têm sido relatadas (Abbott, 2003; Ong et al., 2008). Observou-se que células mesenquimais osteoblásticas cultivadas dentro de hidrogel de colágeno 3D demonstrou um grau superior de diferenciação osteoblástica quando comparadas com o cultivo num substrato de colágeno 2D na presença de suplementos osteoindutores ( $\beta$-glicerofosfato, vitamina $\mathrm{C} e$ dexametasona). Uma diminuição significativa no número de células no colágeno 3D a partir de 3 semanas de também foi observada, o que pode ter ocorrido por causa da maturação e organização da matriz extracelular que rodeia osteoblastos, paralisando a proliferação (Ozawa et al., 2003; Riccio et al., 2010). A expressão de RUNX2 e OC foi significativamente maior nas culturas 3D em comparação com aqueles nas culturas 2D em menos 1 semana. Em contraste, a deposição de cálcio foi gradualmente aumentada ao longo do tempo a partir de 2 semanas de cultura (Naito et al., 2011).

A expressão dos vários genes envolvidos na formção óssea é diferente entre cultura de osteoblastos em condições 2D e 3D (Barron et al., 2010). Estudos, utilizando osteoblastos humanos em culturas 3D, demonstraram um aumento da expressão de OC e ALP em comparação com culturas em monocamada (Kale et al., 2000; Xiao et al., 2003; Trojani et al., 2005; Yefang et al., 2007). Entretanto, outros autores observaram uma baixa expressão de COL I e ALP em culturas 3D de osteoblastos humanos em comparação com monocamada após 7 e 14 dias sem indução osteogênica (Boukhechba et al., 2009). A comparação direta dos resultados derivados de diferentes estudos é difícil, como o desenho experimental geralmente 
varia em termos de composição do biomaterial e geometria do arcabouço, bem como condições de cultura (com ou sem meio osteoindutor) e momentos de coleta de dados (Ferrera et al., 2002; Xiao et al., 2003; Trojani et al., 2005; Yefang et al., 2007; Boukhechba et al., 2009). Em outros relatos, um aumento inicial da expressão de ALP e OC por osteoblastos após o contato inicial célula-célula, seguido por subsequente redução na expressão destes genes com o tempo de cultura, tem sido observada (Hay et al., 2000; Lemonnier et al., 2001).

Embora alguns resultados (Altmann et al., 2011) suportem fortemente a evidência de que 0 ambiente 3D esteja promovendo a diferenciação dos osteoblastos, variações na morfogênese e expressão de marcadores ósseos têm sido observadas, porém estas alterações podem ser devido às diferenças nas características celulares, causadas pelas variações de idade e/ou gênero de origem das células/tecido (Katzburg et al., 1999; Gentleman et al., 2009; Jiang et al., 2010) e interações célula-célula (Altmann et al., 2011).

Estudos realizados com linhagens celulares estabelecidas analisaram o efeito do crescimento em 3D ambientes na diferenciação dos osteoblastos (Botchwey et al., 2001; Rucci et al., 2002), e demonstraram aumento da agregação celular e diferenciação dos osteoblastos. Além disso, os genes osteogênicos, tais como RUNX2, relacionado com a diferenciação de osteoblastos e mineralização foram geralmente expressos em níveis mais elevados em células osteoblásticas cultivadas em ambientes 3D, em comparação com aqueles 2D cultivados (Facer et al., 2005; Ko et al., 2007; Boehrs et al., 2008), observações estão de acordo com outros estudos (Botchwey et al., 2001; Rucci et al., 2002).

Além disso, a diferenciação dos osteoblastos foi melhorada quando cultivados como esferóides ou micromassas, produzindo a sua própria matriz de colágeno (Kale et al., 2000; Gerber; Ap Gwynn, 2002) ou quando foram semeados em vários arcabouços de hidrogéis sintéticos ou naturais (Casser-Bette et al., 1990; Trojani et al., 2005; Weinand et al., 2006). Isso demonstra que as interações celulares são fundamentais para a diferenciação osteobástica.

Resultados obtidos por métodos de cultura usando moléculas de colágeno I solubilizadas mostraram que células osteogênicas mesenquimais mantiveram sua estrutura, diferenciação osteogênica e mineralização. Apesar de a mineralização inicial ter ocorrido independente do colágeno depositado, observou-se nódulos mineralizados depositados perto das fibrilas de colágeno (Mancini et al., 2007). A 
capacidade de proliferação e diferenciação celular foi também mantida em células de medula óssea humana cultivadas sobre géis de colágeno (Fernandes et al., 2009), e a expressão do fenótipo e mineralização foram obsevervadas em células ósseas alveolares humanas semeadas e cultivadas dentro esponjas de colágeno por até 48 dias em cultura (Xiao et al., 2003).

Por outro lado, o revestimento da superfíce plana com colágeno I de não induziu alterações na expressõa de ALP e OC em células de medula óssea de ratos durante 8 dias de cultura (Van Den Dolder; Jansen, 2007). Entretanto, células de calvárias de rato cultivadas em filmes de colágeno do tipo I diferenciam mais rapidamente e expressam níveis mais baixos de COL I no 14ํำ dia em comparação com células cultivadas em poliestireno (Lynch et al., 1995). Portanto, os resultados de baixa espressão do COL, OPN e RUNX2 em células de calvárias de rato cultivadas em superícies de titânio revestidas com colágeno I (Col-Ti) sugerem que a modificação da superfície melhora e/ou acelera o crescimento durante a fase proliferativa e o processo de diferenciação osteoblástica, porém grandes diferenças na mineralização da matriz extracelular, não foram detectadas (Becker et al., 2002; De Assis et al., 2009).

O efeito de vidro bioativos foi avaliado em vários parâmetros-chave da osteogênese in vitro através da cultura de células osteogênicas da calvária de rato recém-nascido sobre os discos de Biosilicato ${ }^{\circledR}$ (uma vitrocerâmica bioativa, completamente cristalizada do sistema $\left.\mathrm{P}_{2} \mathrm{O}_{5}-\mathrm{Na}_{2} \mathrm{O}-\mathrm{CaO}-\mathrm{SiO}_{2}\right)$ e superfícies controles de vidro bioativo por períodos de até 17 dias. Os resultados indicaram que a cristalização completa de vidros bioativos em uma gama de composições do sistema pode promover reforço da formação de tecido in vitro semelhante a osso em um sistema de cultura celular osteogênico (Moura et al., 2007).

Os produtos de dissolução de vidro biativo criam um ambiente extracelular capaz de suportar expressão fenotípica de osteoblastos e deposição de matriz extracelular e mineralização in vitro em osteoblastos humanos. O perfil de expressão do gene das proteínas extracelulares indica que o vidro biativo, com duas concentraçoes de Si diferentes, induziu a diferenciação dos osteoblastos na ausência de suplementos, melhorou significativamente a deposição de matriz extracelular através da indução de mineralização, síntese de OC e COL I e deposição de cálcio, representado por nódulos ósseos positivos por vermelho de Alizarina - coloração especifica para marcar a matriz contendo cálcio, e sua aparência positiva é considerada uma 
expressão de deposição de matriz óssea (Gregory et al., 2004). Células cultivadas na ausência de produtos de dissolução de vidro bioativos não formaram nódulos (Tsigkou et al., 2009).

A integração de células ósseas em um arcabouço composto por fosfato tricálcio (TCP) mostrou um efeito positivo sobre a diferenciação celular e formação de tecido mineralizado quando comparadas com superfíceis plásticas de cultura (Yefang et al., 2007). Os resultados sugerem que o microambiente de cálcio e fosfato pode proporcionar um ambiente fisiológico mais compatível do que a placa de cultura de células utilizada rotineiramente.

Com base nestes estudos, pode ser levantada a hipótese de que esses arcabouços composto poderiam influenciar a ligação, proliferação e diferenciação de células osteoprogenitoras (Yefang et al., 2007). 
3. Proposição 
Objetivo geral:

O objetivo do presente estudo foi avaliar a expressão dos fenótipos fibroblástico e osteoblástico em culturas tridimensionais de fibroblastos do ligamento periodontal humano (hPDLF) e de células osteogênicas da calvária de ratos na presença ou não de partículas de vidro bioativo.

Objetivos específicos:

(i) Identificar a influência das partículas de vidro bioativo na viabilidade, morfologia e produção de matriz mineralizada nas culturas tridimensionais de fibroblastos do ligamento periodontal humano e de células osteogênicas da calvária de ratos recém-nascidos;

(ii) Avaliar a expressão dos fenótipos fibroblástico e osteoblástico de fibroblastos do ligamento periodontal humano e de células osteogênicas da calvária de ratos recém-nascidos em culturas tridimensionais na presença de partículas de vidro bioativo. 
4. Material e Métodos 


\subsection{Grupos experimentais}

A expressão dos fenótipos osteoblástico e fibroblástico foi avaliada nos seguintes grupos:

1) hPDLF no Thermanox ${ }^{\mathrm{TM}}$ (controle)

2) hPDLF no colágeno bidimensional (2D)

3) hPDLF no gel colágeno bidimensional + Biogran® (2D+VB)

4) hPDLF no gel colágeno tridimensional (3D)

5) hPDLF no gel colágeno tridimensional + Biogran ${ }^{\circledR}(3 D+V B)$

6) Células osteoblásticas no Thermanox ${ }^{\mathrm{TM}}$ (controle)

7) Células osteoblásticas no colágeno bidimensional (2D)

8) Células osteoblásticas no colágeno bidimensional + Biogran ${ }^{\circledR}(2 \mathrm{D}+\mathrm{VB})$

9) Células osteoblásticas no gel colágeno tridimensional (3D)

10) Células osteoblásticas no gel colágeno tridimensional + Biogran $®$ $(3 \mathrm{D}+\mathrm{VB})$

\subsection{Preparação dos arcabouços}

As superfícies e arcabouços colágenos foram preparados com colágeno tipo I bovino (Collagen I, bovine, 30 mg, BD Biosciences, MA, EUA). Para a confecção dos arcabouços tridimensionais foram seguidas as recomendações do fabricante e adaptadas para melhor polimerização da solução colágena - Colágeno [2 mg/ml], $\mathrm{NaHCO}_{3}(186 \mathrm{mM}), \mathrm{NaOH}(1 \mathrm{M})$ e meio de cultura Dulbecco's-modified Eagle Medium (DMEM; Gibco). Em seguida, $250 \mu \mathrm{l}$ da solução colágena foram colocados em cada poço em placa de 24 poços contendo lamínula de plástico Thermanox ${ }^{\mathrm{TM}} \mathrm{e}$ levada para a incubadora por 15 minutos para polimerização. Os arcabouços bidimensionais foram preparados através das recomendações do fabricante - 50 $\mu \mathrm{l} / \mathrm{mg}$ do colágeno diluído em solução tampão salina de fosfato (Phosphate Buffered Saline - PBS; Gibco, Invitrogen, Gaithersburg, MD, USA). Em seguida, $100 \mu$ l desta solução colágena foram colocados em cada poço de placa de 24 poços contendo lamínula de plástico Thermanox ${ }^{\mathrm{TM}}$ e mantidos em temperatura ambiente durante $1 \mathrm{~h}$. Após este período, foram aspiradas as soluções remanescentes. Nos grupos com vidro bioativo, as partículas de Biogran ${ }^{\circledR}$ (BIOMET 3i, FL, EUA) foram semeadas 30 $\mu \mathrm{g} /$ poço antes do processo de polimerização e secagem do colágeno. 
Nas superfícies controles foram utilizadas as lamínulas de plástico Thermanox $^{\mathrm{TM}}$, considerando a necessidade de remoção da película para análise da imunofluorescência. .

\subsection{Isolamento e cultura dos fibroblastos do ligamento periodontal humanos}

Os fibroblastos do ligamento periodontal (hPDLF) foram obtidos a partir de prémolares extraídos por indicação ortodôntica e terceiros molares erupcionados com indicação de exodontia de pacientes adultos com periodonto clinicamente saudável usando a técnica do explante previamente descrita (Somerman et al., 1988b) sob aprovação do Comitê de Ética em Pesquisa da USP Campus de Ribeirão Preto (Protocolo $\mathrm{n}^{\circ}$ 2009.1.1206.58.3). Os elementos dentais foram extraídos, lavados duas vezes em solução salina e os fragmentos do ligamento periodontal do terço médio da raiz foram curetados. Os fragmentos foram armazenados em tubos de 50 ml (Corning Incorporated, NY, EUA), contendo meio de transporte - Meio de Dubelcco Modificado por Eagle (DMEM; Gibco Invitrogen, Gaithersburg, MD, EUA), $2,5 \mu \mathrm{g} / \mathrm{ml}$ de vancomicina (Acros Organics, Gell, Bélgica) $250 \mu \mathrm{g} / \mathrm{ml}$ de gentamicina (Gibco) e 312,5 ng/ml de fungizona (Gibco). Após 3 lavagens de $15 \mathrm{~min}$ cada com o meio de transporte, os fragmentos de ligamento periodontal foram cortados em pequenos pedaços, semeados em frascos de $25 \mathrm{~cm}^{2}$ (Fisher Scientific, Pittsburgh, PA, EUA) e cultivados em Dulbecco's-modified Eagle Medium (DMEM; Gibco) contendo $10 \%$ de soro fetal bovino (Gibco), $250 \mathrm{ng} / \mathrm{ml}$ de vancomicina (Acros Organics), $0.5 \mu \mathrm{g} / \mathrm{ml}$ de gentamicina (Gibco), e $50 \mathrm{ng} / \mathrm{ml}$ de fungizona (Gibco) e mantidos em uma atmosfera úmida contendo $5 \%$ de $\mathrm{CO}_{2}$. $\mathrm{O}$ meio de cultura foi trocado a cada 2-3 dias. Após subconfluências, os fibroblastos foram destacados das garrafas com solução de tripsina/EDTA a 0,05 (Gibco), seguido de inativação com meio de cultura. As células destacadas e inativadas foram centrifugadas por 5 min a 2000 rpm e o pellet formado foi ressuspendido em meio de cultura osteogênico - Meio Essencial Mínimo, modificação a, com L-glutamina (a-MEM; Gibco) suplementado com $10 \%$ de soro fetal bovino (FBS) (Gibco), 0,3 $\mathrm{\mu g} / \mathrm{ml}$ de fungizona (Gibco), $50 \mu \mathrm{g} / \mathrm{ml}$ de gentamicina (Gibco), $5 \mu \mathrm{g} / \mathrm{ml}$ de ácido ascórbico (Gibco) e 7 $\mathrm{mM}$ de $\beta$-glicerofosfato (Sigma, St Louis, USA) e dexametazona $10^{7}$ (Sigma) (Rosa;Beloti, 2003; Beloti;Rosa, 2005). Finalmente, as células foram plaqueadas em placas de 24 poços nos diferentes arcabouços e superfícies controle na densidade de $2 \times 10^{4}$ células/poço pelo método over lay em $1 \mathrm{ml}$ de meio de cultura 
osteogênico e mantidas a $37^{\circ} \mathrm{C}$ em uma atmosfera úmida contendo $5 \%$ de $\mathrm{CO} 2$. O meio de cultura foi trocado a cada 2-3 dias e a progressão da cultura foi avaliada por microscopia de fase.

\subsection{Isolamento das células e cultura primária de células osteogênicas}

As células foram isoladas por digestão enzimática sequencial, com solução de tripsina e colagenase (Gibco), de fragmentos de calvárias de ratos Wistar recémnascidos, com 3 dias (Nanci et al., 1996; Irie et al., 1998; De Oliveira et al., 2003; De Oliveira; Nanci, 2004; De Oliveira et al., 2007). Todos os procedimentos com animais estavam de acordo com os Princípios Éticos na Experimentação Animal, adotados pela Comissão de Ética no Uso de Animais (CEUA) da USP Campus de Ribeirão Preto (Protocolo $n^{\circ}$ 0083.0.138.000-09). As células foram plaqueadas diretamente nos diferentes arcabouços em placas de 24 poços (Corning), na densidade de $2 \times$ $10^{4}$ células/poço, juntamente com $1 \mathrm{ml}$ de meio de cultura osteogênico e mantidas a $37^{\circ} \mathrm{C}$ em uma atmosfera úmida contendo $5 \%$ de $\mathrm{CO} 2$. O meio de cultura foi trocado a cada 2-3 dias e a progressão da cultura foi avaliada por microscopia de fase.

\subsection{Viabilidade celular}

A viabilidade celular foi avaliada aos 3, 7 e 10 dias pelo método colorimétrico MTT (Thiazolyl blue tetrazolium bromide). Esse ensaio é dependente da redução do MTT (Sigma, St. Louis, MO, EUA), pela desidrogenase mitocondrial de células viáveis, em formazan, o qual pode ser quantificado por espectrofotometria (Mosmann, 1983). Alíquotas de MTT a $5 \mathrm{mg} / \mathrm{ml}$ em solução tampão salina de fosfato (PBS; Gibco) foram preparadas, procedendo-se em seguida a incubação das culturas primárias com esta solução a $10 \%$ em meio de cultura, por 4 horas a $37^{\circ} \mathrm{C}$, em atmosfera umidificada contendo $5 \%$ de $\mathrm{CO}_{2}$. Após esse período, as culturas foram lavadas com $1 \mathrm{ml}$ de PBS aquecido. Em seguida, foi adicionado $1 \mathrm{ml}$ de solução de isopropanol ácido ( $100 \mathrm{ml}$ de isopropanol e $134 \mu \mathrm{l} \mathrm{de} \mathrm{HCl}$ ) em cada poço sob agitação por $5 \mathrm{~min}$, para a solubilização completa do precipitado formado. Alíquotas de $150 \mu \mathrm{l}$ foram retiradas dos poços e transferidas para placa de 96 poços (Fisher Scientific, Pittsburg, PA, EUA) para medida colorimétrica em espectrofotômetro (iQuanti, BioTek Instruments, Inc., Winooski, EUA), utilizando comprimento de onda de $570 \mathrm{~nm}$. 


\subsection{Conteúdo de proteína total}

A dosagem de proteína total foi realizada aos 7 e 14 dias, seguindo o método de Lowry (Lowry et al., 1951). Os poços foram preenchidos com $1 \mathrm{ml}$ de solução de lauril sulfato de sódio 0,1\% (Sigma, St. Louis, MO, EUA). Ao final de $30 \mathrm{~min}$, a solução contida em cada poço foi homogeneizada e $500 \mu \mathrm{L}$ dessa solução foi transferido para tubos de ensaio. Foi acrescido à cada tubo $500 \mu \mathrm{L}$ de solução de Lowry (Sigma, St. Louis, MO, EUA) e deixados em repouso à temperatura ambiente (TA) por $20 \mathrm{~min}$. Após esse período, foi adicionado a cada tubo $250 \mu \mathrm{l}$ da solução de reagente de fenol de Folin e Ciocalteau's (Sigma, St. Louis, MO, EUA) e novamente deixados em repouso à TA por 30 min. Alíquotas de $150 \mu l$ da solução de cada poço foram transferidas para placas de 96 poços para posterior quantificação. A densidade óptica foi lida em comprimento de onda de $680 \mathrm{~nm}$ em espectrofotômetro ( $\mu$ Quant, Biotek, EUA) e a concentração de proteína total, em $\mu \mathrm{g} / \mathrm{ml}$, calculada a partir de uma curva padrão.

\subsection{Atividade de fosfatase alcalina}

A atividade de ALP foi medida aos 7 e 14 dias através da liberação de timolftaleína pela hidrólise do substrato de timolftaleína monofosfato, utilizando um kit comercial (Labtest, BH, MG, Brasil). Foram utilizados tubos de ensaio branco, padrão e testes. Em todos os tubos foi adicionado $50 \mu \mathrm{l}$ de substrato e $500 \mu \mathrm{l}$ de tampão. No tubo padrão foram acrescentados $50 \mu \mathrm{l}$ da solução padrão. Os tubos foram mantidos em banho maria a $37^{\circ} \mathrm{C}$ por $2 \mathrm{~min}$. Em seguida, foi adicionado, em cada tubo teste, $50 \mu \mathrm{l}$ da suspensão com lauril sulfato de sódio dos mesmos poços utilizados para medida da proteína total. Os tubos foram mantidos em banho maria, a $37^{\circ} \mathrm{C}$ por $10 \mathrm{~min}$. Após esse período foi adicionado em cada tubo, branco, padrão e testes, $2 \mathrm{ml}$ do reagente de cor. Alíquotas de $150 \mu \mathrm{l}$ da solução de cada poço foram transferidas para placas de 96 poços para posterior quantificação. A densidade óptica foi lida em comprimento de onda de $590 \mathrm{~nm}$ em espectrofotômetro e os dados expressos como absorbância. A atividade de ALP, expressa em $\mu$ mol de timolftaleína/h/mg, foi calculada a partir da medida do tubo padrão e normalizada pela quantidade de proteína total. 


\subsection{Localização de proteínas da matriz extracelular não-colágena por imunofluorescência indireta}

Em 7 e 14 dias, as células semeadas no grupo controle e nas superfícies colágenas bidimensionais (2D e 2D+VB) foram fixadas em paraformaldeído a $4 \%$ em tampão fosfato a 0,1 M, pH 7,2 (PB), por 10 min à TA. Em seguida, as células foram processadas rotineiramente para imunofluorescência indireta (De Oliveira; Nanci, 2004; De Oliveira et al., 2007). As células foram permeabilizadas com solução de Triton X-100 a 0,5\% (Acros Organics, Geel, EUA) em PB por 10 min, seguida de bloqueio com leite desnatado a $5 \%$ em PB por 30 min. Utilizaram-se anticorpos primários monoclonais para BSP (1:200, WVID1-9C5, Developmental Studies Hybridoma Bank - DSHB, lowa, EUA) e OPN (1:800, MPIIIB10-1,) e ALP (1:100, B478, DSHB, lowa, EUA), seguidos de anticorpos secundários conjugados com fluoróforo Alexa Fluor 594 (fluorescência vermelha; 1:200, Molecular Probes) em mesma solução de faloidina conjugada com Alexa Fluor 488 (fluorescência verde; 1:200, Molecular Probes), para visualização do citoesqueleto de actina. Todas as incubações dos anticorpos foram feitas em atmosfera úmida por 60 min à TA. Entre cada incubação, as amostras foram lavadas três vezes (5 min cada) em PB. Antes da montagem para observação microscópica, as amostras foram lavadas, rapidamente, com água destilada e os núcleos celulares, marcados com 4',6diamidino-2-phenylindole, dihydrochloride (DAPI, Molecular Probes) a $300 \mathrm{nM}$ por 5 min. Os arcabouços foram montados diretamente em lâminas de vidros e, em seguida, após montagem de lamínula de vidro Fisherbrand $12 \mathrm{~mm}$ (Fisher Scientific) com meio de montagem anti-fade (Prolong Gold $^{\circledR}$, Molecular Probes) sobre as superfícies contendo células, as marcações foram examinadas em microscópio de fluorescência (Axio Imager, Zeiss, Jena, Alemanha) acoplado a uma câmara fotográfica digital (AxionCam MRm, Zeiss, Jena, Alemanha). As imagens foram sobrepostas e analisadas utilizando-se o software Adobe Photoshop.

Para os grupos tridimensionais (3D e 3D+VB), foi utilizado o mesmo protocolo de preparação das amostras bidimensionais e controle. As a obtenção das imagens foram feitas utilizando o microscópio confocal (Leica TCS-SP2 SE) e seguindo metodologia utilizada no Laboratório Multiusuário de Microscopia Confocal da USP/Ribeirão Preto. 


\subsection{Expressão quantitativa dos genes por reação em cadeia da polimerase em tempo real (Real-time PCR)}

Aos 7 dias foi avaliada a expressão dos genes fosfatase alcalina (ALP), osteopontina (OPN), osteocalcina (OC), colágeno I (COL I), RUNX2 e sialoproteína óssea (BSP), que caracterizam o fenótipo osteoblástico, nas culturas de células osteogênicas da calvária de ratos recém-nascido

Aos 7 e 14 dias foi avaliada a expressão dos genes periostina (PRT), calciumbinding protein (S100A4) e fibromodulina (FBM), que caracterizam o fenótipo fibrolástico nas culturas de fibroblastos do ligamento periodontal. Além destes, foram analisados os genes que caracterizam o fenótipo osteoblástico (ALP, OPN, OC, COL I e Runx2), para testar se as condições tridimensionais das culturas fibroblásticas na presença ou não de partículas de Biogran ${ }^{\circledR}$ favorecem o desenvolvimento do fenótipo de células capazes de produzir matriz mineralizada. Como controle foi avaliada a expressão do gene constitutivo para $\beta$-actina (ACTB). As sequências dos primes utilizados estão nas tabelas 1 e 2.

Para o estudo da expressão gênica a densidade de plaqueamento foi $4 \times 10^{4}$ células/poço sobre os arcabouços tridimensionais. A análise de expressão gênica foi realizada por $R T$ - PCR como descrito a seguir.

\subsubsection{Extração de RNA total para PCR em tempo real}

O meio de cultura foi removido de todos os poços da placa de cultura e, em seguida, adicionado $1 \mathrm{ml}$ do reagente Trizol (Invitrogen, Carlsbad, CA, EUA) no primeiro poço. Após homogeneização, para promover lise das células, esta mistura foi transferida para o próximo poço, e o mesmo procedimento realizado até o último poço de cada grupo avaliado. Ao final de 20 poços, foi possível obter quantidade suficiente de RNA total para realização de todos os experimentos de PCR em real time. As amostras foram mantidas a TA durante 15 min e armazenadas no freezer $20^{\circ} \mathrm{C}$ por, no mínimo, 24 horas.

Decorrido este período, para cada $1 \mathrm{ml}$ da suspensão células-trizol foram adicionados $200 \mu \mathrm{l}$ de clorofórmio (Merck, Darmstadt, Alemanha). Os tubos foram manualmente agitados por $30 \mathrm{~s}$ e mantidos no gelo durante $5 \mathrm{~min}$. A seguir, as amostras foram centrifugadas a $4^{\circ} \mathrm{C}$ e $10.500 \mathrm{rpm}$, por $15 \mathrm{~min}$, e a fase aquosa (superior) coletada em novos tubos de 1,5 ml (Eppendorf AG, Hamburg, Alemanha). Em seguida, foram adicionados $250 \mu \mathrm{l}$ de etanol 96\% (Merck, Darmstadt, Alemanha) 
às amostras e as mesmas centrifugadas em colunas de sílica gel presentes no kit SV Total RNA Isolation System (Promega, Madison, Wisconsin, EUA). A solução amostra/etanol foi agitada delicadamente e transferida para uma nova coluna de sílica gel. Foram adicionados tampões específicos, intercalados por rápidas centrifugações de $15 \mathrm{~s}$ a 10.500 rpm cada. Após várias lavagens com estes diferentes tampões, as amostras de RNA foram eluídas da coluna com $25 \mu$ de água deionizada e tratada com dietylpyrocarbonate (DEPC, Acros Organics), livre de RNAse, e armazenadas a $-80^{\circ} \mathrm{C}$, até a confecção do DNA complementar (cDNA). Para o preparo da água adiciona-se $1 \mathrm{ml}$ de DEPC em $999 \mathrm{~mL}$ de água deionizada, sendo esta mistura incubada por 24 horas e autoclavada por 30 min a $121^{\circ} \mathrm{C}$.

\subsubsection{Quantificação do RNA}

Para a quantificação das amostras de RNA total, uma alíquota de $2 \mu$ foi diluída em $198 \mu \mathrm{l}$ de água DEPC, e analisada por espectrofotometria utilizando o aparelho Genequant 1300 (GE Healthcare, EUA). A leitura foi realizada nos comprimentos de onda de $260 \mathrm{~nm}$ (ácido nucléico), $280 \mathrm{~nm}$ (proteína) e $230 \mathrm{~nm}$ (fenol), para detectar a concentração de RNA/ $\mu$ I nas amostras e contaminação por fenol ou proteínas.

\subsubsection{Confecção da fita de DNA complementar (cDNA)}

O DNA complementar (cDNA) foi sintetizado a partir de $1 \mu \mathrm{g}$ de RNA total por reação de transcrição reversa utilizando-se o kit High-capacity cDNA Reverse Transcription Kits (Applied Biosystems, Foster City, Califonia, EUA), de acordo com as instruções do fabricante. Brevemente, em um tubo de $200 \mu$ l (Eppendorf AG, Hamburg, Alemanha) foram adicionados: $1 \mu \mathrm{g}$ de RNA total diluído em um volume final de $10 \mu \mathrm{l}$ de água previamente tratada com DEPC, $2 \mu \mathrm{l}$ de reverse transcriptase (RT) buffer, 0,8 $\mu$ l de deoxinucleotídeo (dNTP mix), $2 \mu \mathrm{L} R T$ Random Primer, $1 \mu \mathrm{l}$ de MultiScribe ${ }^{T M}$ Reverse Transcriptase, $1 \mu$ de RNase Inhibitor e 3,2 $\mu$ l de água DEPC, para um volume final de $20 \mu \mathrm{l} /$ reação. Em seguida, as amostras foram incubadas em termociclador Master Cycler Gradiente (Eppendorf AG) sob as seguintes condições: $25^{\circ} \mathrm{C}$ por $10 \mathrm{~min}, 37^{\circ} \mathrm{C}$ por $120 \mathrm{~min}, 85^{\circ} \mathrm{C}$ por $5 \mathrm{~min}$, seguido pelo resfriamento a $4^{\circ}$ C. Ao final da reação de transcrição reversa as amostras de cDNA foram estocadas em freezer $-20^{\circ} \mathrm{C}$. 


\subsubsection{Reação em cadeia da polimerase (PCR) em tempo real}

Para realização da PCR em tempo real foi utilizado o sistema SYBR Green, em um aparelho CFX 96 (Bio-Rad, California, EUA). Foram utilizados $7 \mu$ do reagente SYBR Green Master Mix (Applied Biosystems) que contém o fluoróforo SYBR Green, a enzima polimerase AmpliTaq Gold, dNTPs com dUTP e o fluoróforo ROX, utilizado como referência passiva para normalização dos níveis de fluorescência, além dos demais componentes de tampão, 2,5 $\mu \mathrm{l}$ da solução de cDNA, 2,5 $\mu \mathrm{l}$ de água Milli-Q tratada com DEPC e 0,5 $\mu \mathrm{l}$ da solução contendo cada primer com as concentrações adequadas.

A reação de amplificação compreendeu $2 \min$ a $50^{\circ} \mathrm{C}, 10 \min$ a $95^{\circ} \mathrm{C}$, quarenta ciclos de $15 \mathrm{~s}$ a $95^{\circ} \mathrm{C}$ e $1 \mathrm{~min}$ a $60^{\circ} \mathrm{C}$, além de um ciclo final de $20 \mathrm{~min}$, com temperatura crescente de $60^{\circ} \mathrm{C}$ a $95^{\circ} \mathrm{C}$, empregado para a obtenção de uma curva de dissociação dos produtos da reação, utilizada para a análise da especificidade de amplificação. Os resultados foram analisados com base no valor do ciclo limiar $(\mathrm{Ct}$ do inglês cicle threshold).

Cada placa foi corrida em duplicata e a amplificação foi realizada no termociclador CFX 96 (Bio-Rad, Berkeley, California, EUA) por 40 ciclos conforme protocolo do fabricante. A fluorescência foi coletada para cada ciclo de amplificação e os dados analisados pelo método $2^{-\Delta \Delta C t}$ para quantificação da expressão relativa (Livak;Schmittgen, 2001). A validação dos ensaios e eficiência da amplificação de cada primer foi calculada conforme User Bulletin (Applied Biosystems) e os valores obtidos do slope ficaram entre 95 e 100\%.

A normalização e quantificação relativa da expressão gênica foram realizadas pelo método de $2^{-\Delta \Delta C T}$ (Livak;Schmittgen, 2001). Usando o método de $2^{-\triangle \Delta C T}$, os dados foram representados como diferença (em vezes) na expressão gênica, a qual foi normalizada pelo gene constitutivo e é relativa às culturas realizadas sobre os discos do grupo controle. Uma amostra negativa (água) foi submetida à reação com cada par das sequências dos primers utilizados. 
Tabela 1 - Sequências dos primers utilizados na análise de expressão gênica por RT-PCR para as células hPDLF

\begin{tabular}{|c|c|c|}
\hline \multirow{3}{*}{$\begin{array}{c}\text { Genes } \\
\text { B-actina }\end{array}$} & \multicolumn{2}{|r|}{ Sequências } \\
\hline & Forward & 5'-ATGTTTGAGACCTTCAACA-3' \\
\hline & Reverse & 5'-CACGTCAGACTTCATGATGG-3' \\
\hline \multirow{2}{*}{ FBM } & Forward & 5'-AAGGAGGCCAGACAGAGGGA-3' \\
\hline & Reverse & 5'-GGTCATCTTCATACTGGGCC-3' \\
\hline \multirow{2}{*}{ S100A4 } & Forward & 5'-TTCCACAAGTACTCGGGCAAA-3' \\
\hline & Reverse & 5'-TGTTGCTGTCCAAGTTGCTCAT-3' \\
\hline \multirow{2}{*}{ PRT } & Forward & 5'-TCACTTCАСАСТСТTTGСТСССАС-3' \\
\hline & Reverse & 5' TCCCATAATAGACTCAGAACACTGGAGA-3' \\
\hline \multirow{2}{*}{ Runx2 } & Forward & 5'-TATGGCACTTCGTCAGGATCC-3' \\
\hline & Reverse & 5'AATAGCGTGCTGCCATTCG-3` \\
\hline \multirow{2}{*}{ COL I } & Forward & 5'-TGACGAGACCAAGAACTG-3' \\
\hline & Reverse & 5'-CCATCCAAACCACTGAAACC-3' \\
\hline \multirow{2}{*}{ ALP } & Forward & 5'-ACGTGGCTAAGAATGTCATC-3' \\
\hline & Reverse & 5'-CTGGTAGGCGATGTCCTTA-3' \\
\hline \multirow{2}{*}{ OPN } & Forward & 5'-AGACACATATGATGGCCGAGG-3' \\
\hline & Reverse & 5'-GGCCTTGTATGCACCATTCAA-3' \\
\hline \multirow{2}{*}{ OC } & Forward & 5'-CAAAGGTGCAGCCTTTGTGTC-3' \\
\hline & Reverse & 5'-TCACAGTCCGGATTGAGCTCA-3' \\
\hline
\end{tabular}

Tabela 2 - Sequências dos primers utilizados na análise de expressão gênica por RT-PCR para as células osteogênicas

\begin{tabular}{|c|c|c|}
\hline Genes & & Sequências \\
\hline \multirow{2}{*}{$\beta$-actina } & Forward & 5'-TGGGTATGGAATCCTGCTGC-3' \\
\hline & Reverse & 5'-CAGCTCAGTAACAGTCCG-3' \\
\hline \multirow{2}{*}{ Runx2 } & Forward & 5'-GAACTGATAGGACGCTGACGA-3' \\
\hline & Reverse & 5'-GCTTCTCCAACCCACGAATG-3' \\
\hline \multirow{2}{*}{ COL I } & Forward & 5'-TCCTGCCGATGTCGCTATC-3' \\
\hline & Reverse & 5'-CAAGTTCCGGTGTGACTCGTG-3' \\
\hline \multirow{2}{*}{ ALP } & Forward & 5'-CGAGCAGGAACAGAAGTTTGC-3' \\
\hline & Reverse & 5'-TGGCCAAAAGGCAGTGAATAG-3' \\
\hline \multirow{2}{*}{ OPN } & Forward & 5'-GCCTGTTCGGCCTTGCCTCCTGTCT-3' \\
\hline & Reverse & 5'-TCAGTCCGTAAGCCAAGCTATCACC-3' \\
\hline \multirow{2}{*}{ OC } & Forward & 5'-GCAGACACCATGAGGACCCT-3' \\
\hline & Reverse & 5'-CCAGAGTCTATTCACCACCTTACTG-3' \\
\hline \multirow{2}{*}{ BSP } & Forward & 5'-СTACTTTTATCCTCCTCCTCTGAAACGGTT-3 \\
\hline & Reverse & 5'-GCTAGCGGTTACCCCTGAGA-3' \\
\hline
\end{tabular}




\subsection{Mineralização}

A mineralização foi avaliada aos 10 e 14 dias, através da marcação de depósitos de cálcio utilizando vermelho de Alizarina (Sigma). O meio de cultura foi removido, os poços lavados três vezes com PBS aquecido a $37^{\circ} \mathrm{C}$ e preenchidos com paraformaldeído a $4 \%$ por 24 horas. Em seguida, os poços foram desidratados em série crescente de álcoois e as culturas processadas para coloração com vermelho de Alizarina (Sigma, St. Louis, MO, EUA). Em seguida as amostras foram observadas por microscopia de fluorescência, em epiluminação. Imagens microscópicas das áreas marcadas com vermelho de Alizarina nas culturas foram obtidas em microscópio de fluorescência (Axio Imager, Zeiss, Jena, Alemanha) acoplado a uma câmara fotográfica digital (AxionCam MRm, Zeiss, Jena, Alemanha).

A quantificação da coloração foi avaliada por método colorimétrico (Gregory et al., 2004). Foram adicionados $280 \mu$ de ácido acético a $10 \%$ a cada poço previamente corado com vermelho de Alizarina, e a placa foi levada ao agitador por 30 minutos em temperatura ambiente. O conteúdo de cada poço foi transferido para tubos tipo eppendorf $(1,5 \mathrm{ml})$, e então aquecidos a $85^{\circ} \mathrm{C}$ por 10 minutos e depois mantidos em gelo por 5 minutos. Os tubos foram levados para centrífuga a $1300 \mathrm{rpm}$ por 20 minutos, e $100 \mu \mathrm{l}$ do sobrenadante de cada tubo foi transferido para um novo tubo. Então $40 \mu \mathrm{l}$ de hidróxido de amônia a 10\% foram adicionados a casa tudo para neutralizar o ácido, e todo o conteúdo $(140 \mu \mathrm{l})$ foi transferido para uma placa de 96 poços. A absorbância foi medida em um espectofotômetro ( $\mu$ Quant, BioTek Instruments, Inc., Winooski, VT, EUA) no comprimento de onda de $405 \mathrm{~nm}$. A formação de matriz mineralizada foi expressa como densidade óptica.

\subsection{Análise estatística}

Para cada cultura de ambos os tipos celulares ( 3 para cada análise), os experimentos foram realizados em quintuplicata $(n=5)$, exceto para os experimentos de análise de expressão gênica que foram realizados em triplicata $(n=3)$ e os resultados quantitativos, submetidos ao teste Kruskal-Wallis, para dados nãoparamétricos e quando apropriado, foi aplicado o pós-teste de comparações múltiplas de Dunn. Para os dados paramétricos foi aplicado o teste One way ANOVA, seguido do pós-teste de Tukey para as comparações múltiplas, quando necessário. O nível de significância foi de $5 \%$. 
5. Capítulo I 
No Capítulo I, foram considerados os resultados dos experimentos com fibroblastos do ligamento periodontal

\subsection{Resultados}

\subsubsection{Viabilidade celular}

De forma geral, todos os grupos mostraram uma viabilidade celular crescente de acordo com os períodos avaliados. O ensaio colorimétrico MTT revelou diferenças significantes na viabilidade das culturas crescidas nos diferentes grupos avaliados apenas aos 3 dias ( $p<0,001$; Figura 1). As células em 2D+VB exibiram índice de viabilidade estatisticamente maior que na superfície controle $(p<0,05)$. Aos 7 e 10 dias, as culturas em 3D apresentaram maiores índices de viabilidade; porém não foram observadas diferenças significativas nesses períodos entre os grupos. As células cultivadas na superfície controle exibiram os menores níveis de viabilidade celular ao final de todos os períodos avaliados.

\section{Viabilidade celular}

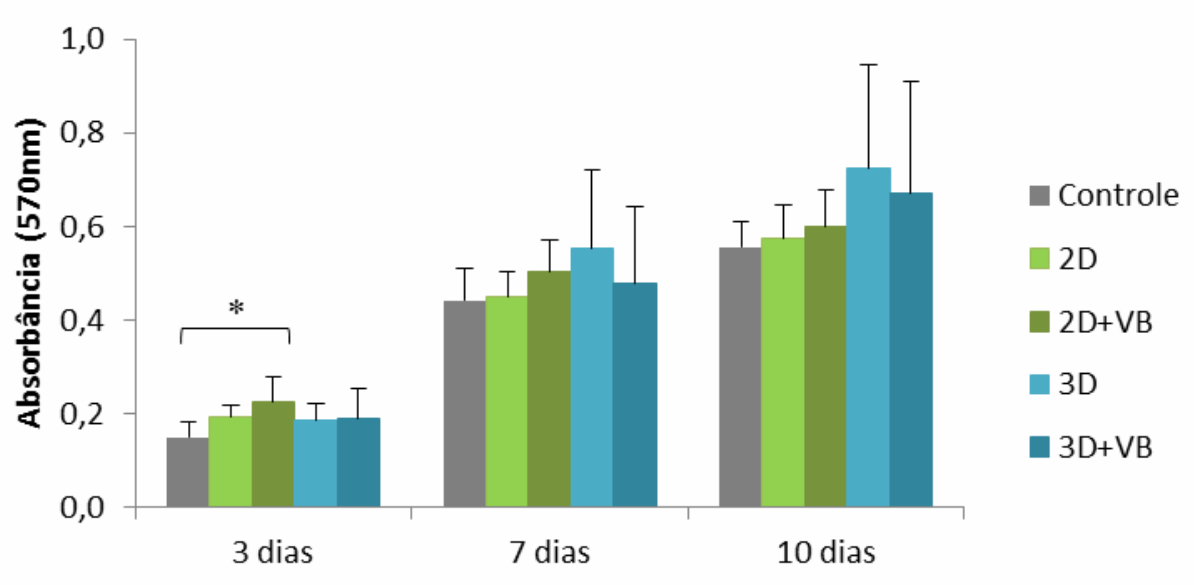

Figura 1. Viabilidade celular (média \pm desvio padrão, em densidade óptica) de culturas de células hPDLF crescidas na superfície controle e nos diferentes grupos, determinada pelo ensaio colorimétrico MTT, em 3, 7 e 10 dias. * indica diferença estatisticamente significante $(p<0,05)$ na análise comparativa mútipla (pós-teste de Tukey) após o teste One Way ANOVA. 


\subsubsection{Conteúdo de proteína total}

O conteúdo de proteína total que foi determinado usando o método de Lowry apresentou diferenças significantes nas culturas em arcabouços e superfícies avaliados aos 7 e 14 dias ( $p<0,001$; Figura 2). Os resultados mostraram que a quantidade de proteína total foi significantemente maior nas culturas tridimensionais (3D e 3D+VB) quando comparadas com superfície controle $(p<0,05)$ e em 3D+VB comparada com 2D+VB $(p<0,05)$ aos 7 dias. O conteúdo de proteína total em 3D foi significantemente maior que $2 \mathrm{D}(p<0,05)$ aos 14 dias.

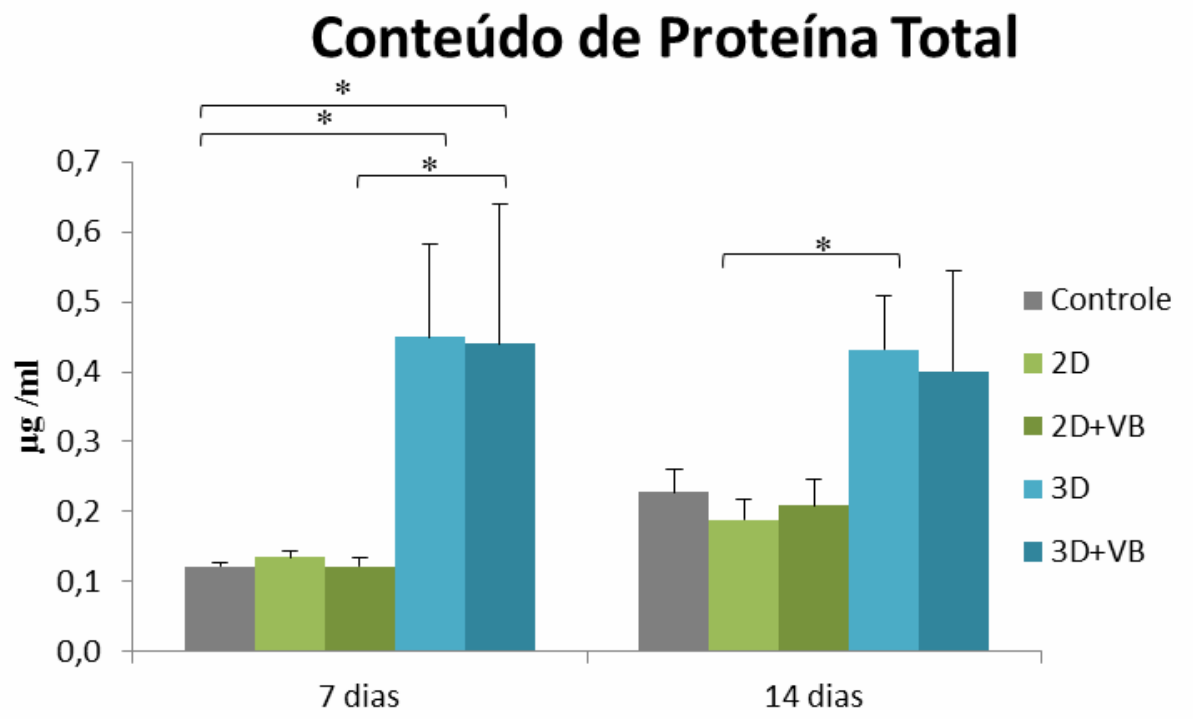

Figura 2. Medida do conteúdo de proteína total (média \pm desvio padrão, em densidade óptica) de culturas de células hPDLF crescidas na superfície controle e nos diferentes grupos, expressa como $\mu \mathrm{g} / \mathrm{ml}$, em 7 e 14 dias. * indica diferença estatisticamente significante $(p<0,05)$ na análise comparativa múltipla (pós-teste de Dunn) após o teste Kuskal-Wallis.

\subsubsection{Atividade de fosfatase alcalina}

Os resultados revelaram diferenças significantes na atividade de fosfatase alcalina de culturas crescidas nos diferentes arcabouços e superfícies avaliados aos 7 e 14 dias ( $p<0,001$; Figura 3). Aos 7 dias a atividade de ALP foi maior em 2D e 2D+VB. Diferenças significativas foram encontradas quando comparados 3D com 2D $(p<0,05)$; e 3D+VB com 2D+VB $(p<0,05)$ e controle $(p<0,05)$. Entretanto, aos 14 dias foi observado que as células semeadas nos arcabouços tridimensionais (3D e 3D+VB) apresentaram maior atividade de ALP, significantemente diferente daquelas cultivadas sobre a superfície controle, as quais apresentaram menor atividade de ALP. 


\section{Atividade de Fosfatase Alcalina}

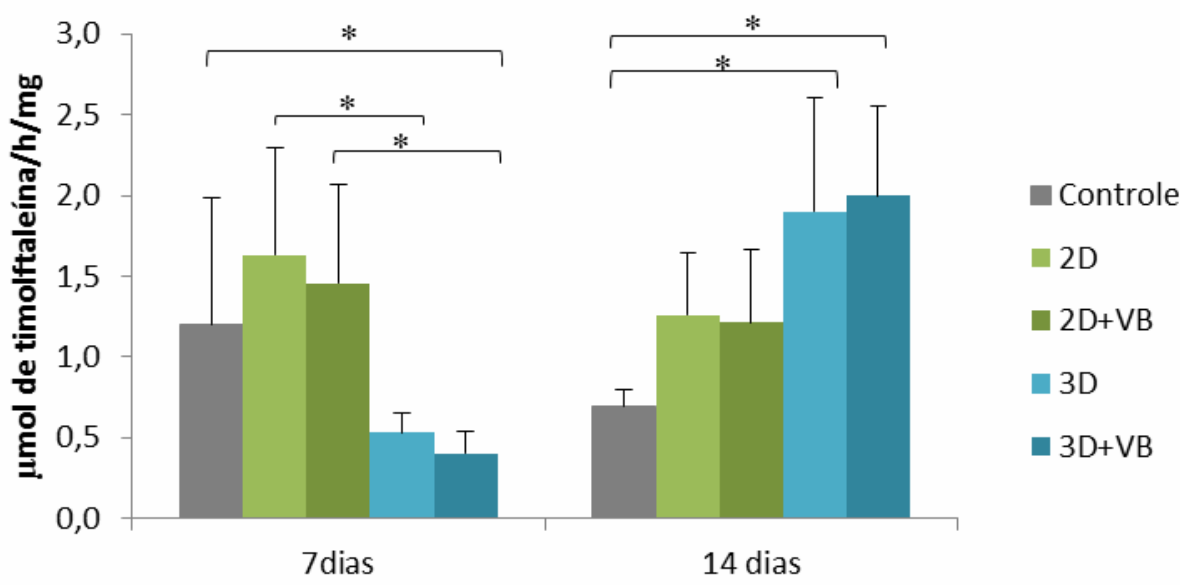

Figura 3. Medida da atividade de fosfatase alcalina (média \pm desvio padrão, em densidade óptica) de culturas de células hPDLF crescidas na superfície controle e nos diferentes grupos, expressa como $\mu \mathrm{mol}$ de timolftaleína/h/mg, em 7 e 14 dias. * indica diferença estatisticamente significante $(p<0,05)$ na análise comparativa múltipla (pós-teste de Dunn) após o teste Kuskal-Wallis.

\subsubsection{Localização de proteínas da matriz extracelular não-colágena por imunofluorescência indireta}

Foi realizada a imunolocalização de proteínas da matriz extracelular nãocolágena: fosfatase alcalina (ALP) e osteopontina (OPN) nas culturas com células hPDLF nos períodos de 7 e 14 dias.

As células cultivadas nas superfícies bi-dimensionais colágenas e controle apresentaram uma forma mais achatada ou poligonal, com um citoesqueleto bem organizado, e fibras de stress de actina definidas, mostrado aqui em verde. Uma camada de células mais densa pode ser observada, indicando que a proliferação celular ocorreu. Aos 7 dias não foram observadas imunomarcações positivas para ALP e OPN nas células em contato com essas superfícies através de microscopia por epifluorescência.

Nos arcabouços tridimensionais as células apresentaram um aspecto mais fusiforme alongado, também um citoesqueleto bem organizado, e fibras de stress de actina definidas. Uma pequena proporção da imunomarcação positiva de ALP foi visualizada principalmente através de depósitos perinucleares e pontos no citoplasma das células semeadas no 3D através de microscopia confocal. A marcação para OPN foi observada principalmente ao redor dos núcleos em células no 3D, porém não foram observadas marcações de ambas as proteínas nas células em 3D+VB.

Aos 14 dias a imunomarcação ALP foi predominantemente extracelular nas superfícies 2D e controle de uma maneira semelhante, e perto das partículas de 
vidro bioativo nas culturas 2D+VB. Em 3D a marcação positiva para ALP foi obervada principalmnte em áreas perinucleares das células. A OPN foi detectada apenas ocasionalmente em células nas superfícies 2D e controle, sendo predominantemente uma marcação perinuclear e extracelular. Pequena positividade de OPN foi observada perto das partículas de vidro bioativo em 2D+VB e marcações perinucleares e em pontos dispessos no citoplasma das células semeadas em 3D. Nenhuma marcação para ALP e OPN foi observada em 3D+VB.

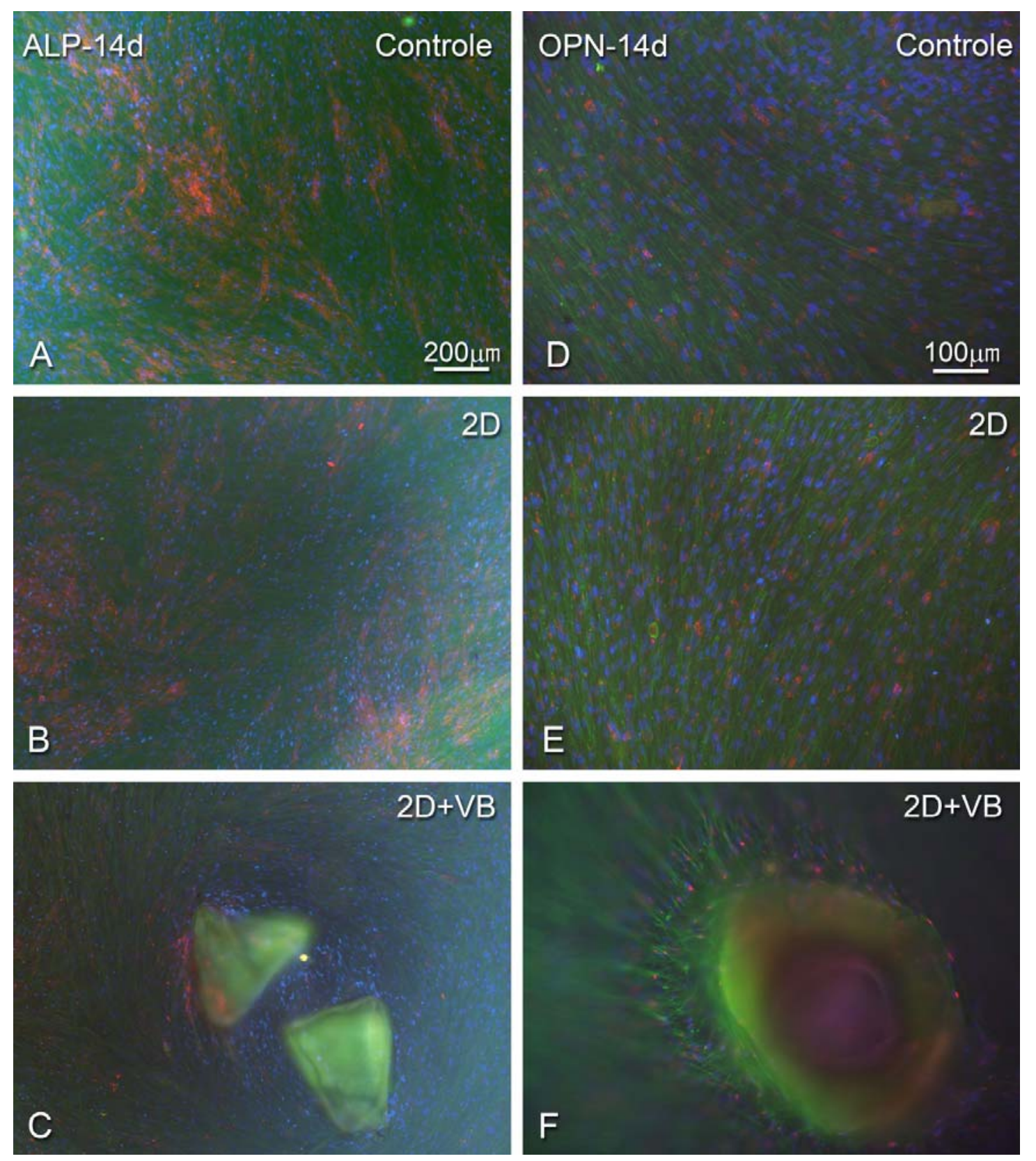

Figura 4. Epifluorescência de culturas de células hPDLF crescidas sobre as diferentes superfícies bidimensionais no período de 14 dias. Marcação em vermelho indica ALP em A-C e OPN em D-F. Fluorescência verde revela citoesqueleto de actina em $A-F$, enquanto que a azul, os núcleos celulares (A-F). A barra de escala indica $200 \mu \mathrm{m}$ para A-C e $100 \mu \mathrm{m}$ para D-F. 


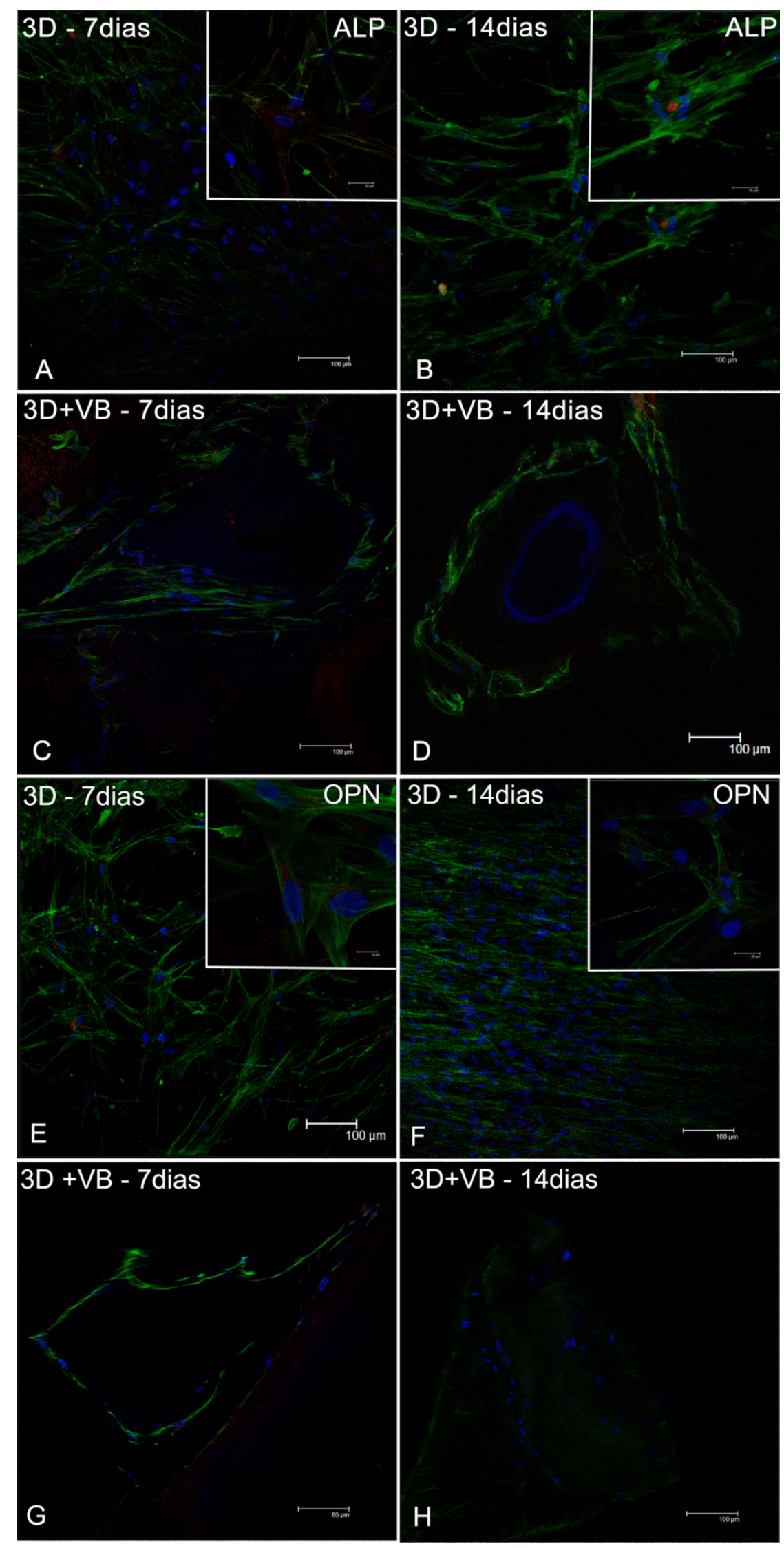

Figura 5. Microscopia confocal de culturas de células hPDLF crescidas sobre os arcabouços tridimensionais 3D (A-B-E-F) e 3D+VB (C-D-G-H). Marcação em vermelho indica ALP (A-C) e OPN (E-G) em 7 dias ALP (B-D) e OPN (F-H) em 14 dias (Fluorescência verde revela citoesqueleto de actina e florescência azul, os núcleos celulares (A-D). 


\subsubsection{Expressão quantitativa dos genes por reação em cadeia da polimerase em tempo real (Real-time PCR)}

\subsubsection{Expressão de RNAm de marcadores do fenótipo fibroblástico}

Em 7 dias, os ensaios de PCR em tempo real mostraram diferenças nos níveis de expressão do RNAm para $\operatorname{PRT}(p=0,001), \operatorname{FBM}(p=0,001)$ e S100A4 $(p=0,005)$. Culturas crescidas nos arcabouços tridimensionais (3D e 3D+VB) apresentaram um perfil de expressão gênica para PRT upregulated em relação às crescidas na superfície controle (Figura 6). A expressão de FBM foi significativamente maior nas culturas $3 \mathrm{D}$ e $2 \mathrm{D}$ comparadas com 3D+VB $(p<0,05)$ (Figura 7). As células em 2D apresentaram nível de expressão de RNAm para S100A4 significativamente maior que as crescidas em 2D+VB $(p<0,05)$ e controle $(p<0,05)$ (Figura 8).

Em 14 dias, os ensaios de PCR em tempo real também mostraram diferenças nos níveis de expressão de RNAm para PRT $(p<0,001)$, FBM $(p=0,001)$ e S100A4 $(p=0,016)$. Observou-se que houve uma diminuição da expressão de todos os genes analisados (Figuras 6, 7 e 8) em relação às análises de 7 dias. As células em 2D+VB expressaram maiores níveis de PRT, estatisticamente diferente de 3D+VB $(p<0,05)$ (Figura 6). Os maiores níveis de expressão de FBM foram observados em 2D e $2 \mathrm{D}+\mathrm{VB}$ e os menores nas culturas tridimensionais (3D e 3D+VB) (Figura 7). Os níveis de expressão do gene S100A4 foram maiores em 2D e 2D+VB respectivamente, sendo em 2D estatisticamente diferente que em 3D $(p<0,05)$ (Figura 8). 


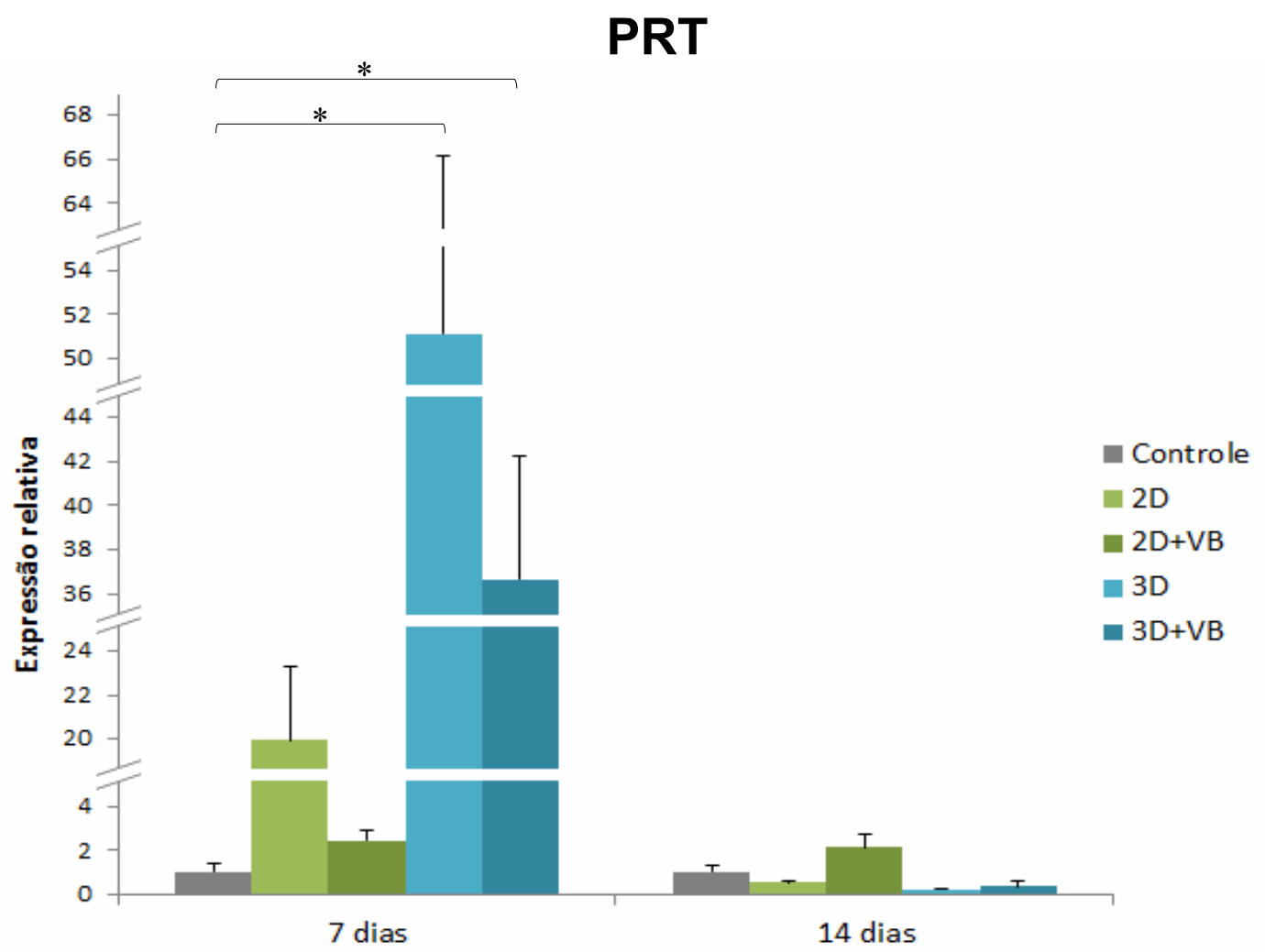

Figura 6. Expressão relativa de RNAm (média \pm desvio padrão) para Periostina (PRT) em culturas de células hPDLF crescidas nos diferentes grupos, avaliada aos 7 e 14 dias. Os valores foram normalizados pelo gene constitutivo $\beta$-actina e calibrados pelo controle. * indica diferença estatisticamente significante $(p<0,05)$ na análise comparativa (pós-teste de Dunn), após o teste Kruskal-Wallis.

\section{FBM}

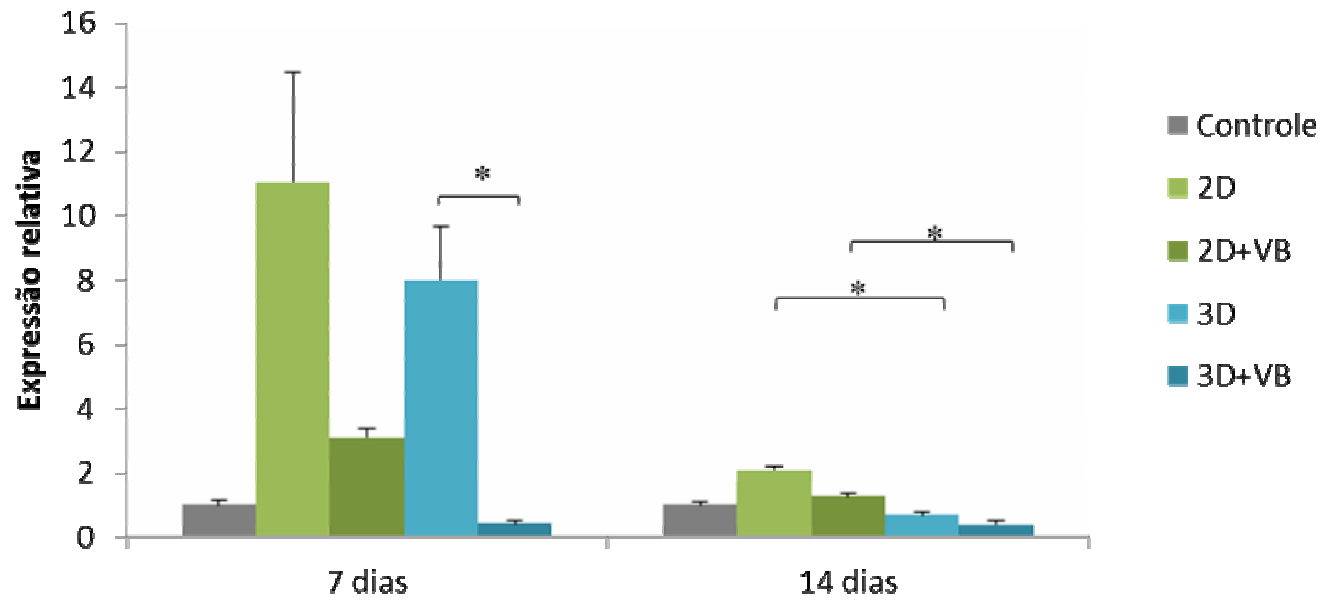

Figura 7. Expressão relativa de RNAm (média \pm desvio padrão) para Fibromodulina (FBM) em culturas de células hPDLF crescidas nos diferentes grupos, avaliada aos 7 e 14 dias. Os valores foram normalizados pelo gene constitutivo $\beta$-actina e calibrados pelo controle. * indica diferença estatisticamente significante $(p<0,05)$ na análise comparativa (pós-teste de Dunn), após o teste Kruskal-Wallis. 


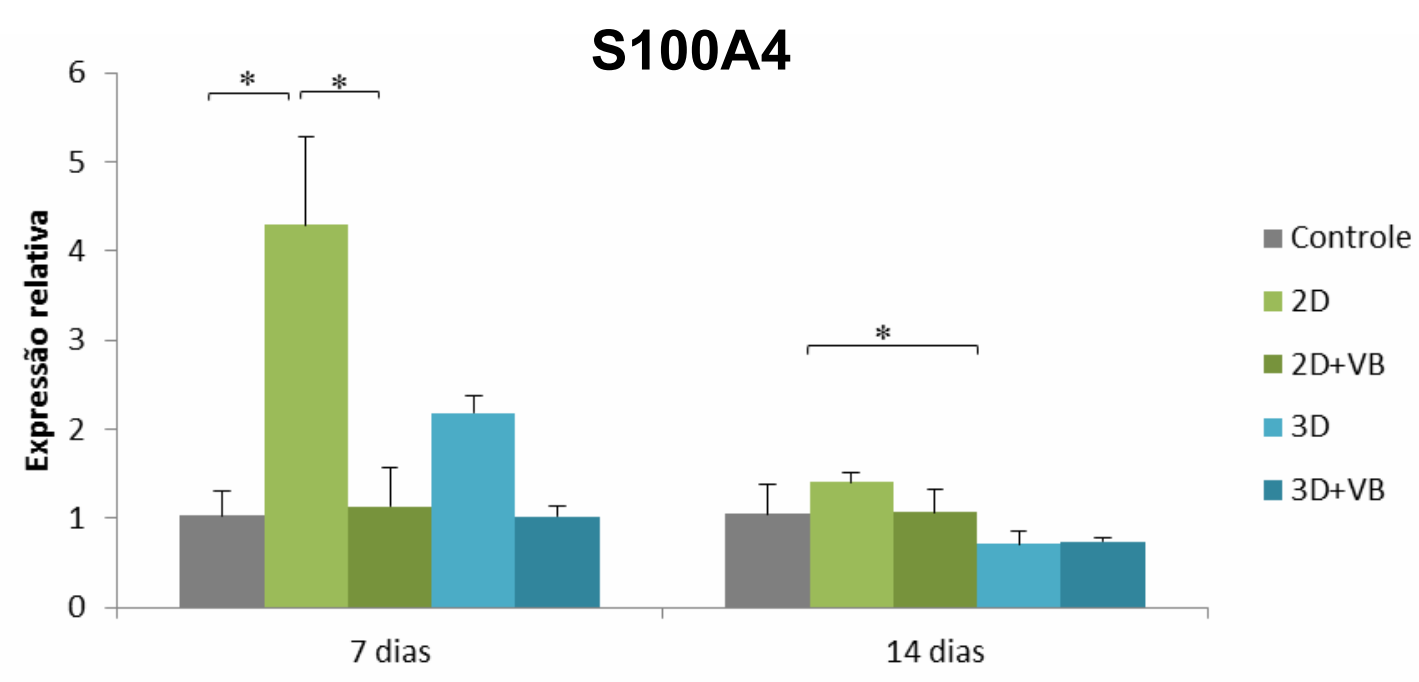

Figura 8. Expressão relativa de RNAm (média \pm desvio padrão) para S100A4 em culturas de células hPDLF crescidas nos diferentes grupos, avaliada aos 7 e 14 dias. Os valores foram normalizados pelo gene constitutivo $\beta$-actina e calibrados pelo controle. * indica diferença estatisticamente significante $(p<0,05)$ na análise comparativa (pós-teste de Dunn), após o teste Kruskal-Wallis.

\subsubsection{Expressão de RNAm de marcadores do fenótipo osteoblástico}

Em 7 dias, os ensaios de PCR em tempo real mostraram diferenças nos níveis de expressão de RNAm para COL I $(p<0,001)$, ALP $(p=0,003)$, RUNX2 $(p=0,002)$, OPN $(p=0,001)$ e OC $(p=0,002)$. Culturas crescidas em $2 D+V B$ e 3D apresentaram níveis de COL I e ALP upregulated em relação ao do controle (Figuras 9 e 10). A expressão de RUNX2 e OPN pelas células em 3D e 2D também mostrou-se upregulated em relação ao controle, sendo para OPN, em 3D a expressão gênica estatisticamente maior que em 2D $(p<0,05)$ (Figuras 11 e 12). As células crescidas em 2D apresentaram nível de expressão de RNAm para OC significativamente maior que no controle $(p<0,05)$ e em $2 \mathrm{D}+\mathrm{VB}(p<0,05)$ (Figura 13).

Em 14 dias os ensaios de PCR em tempo real também mostraram diferenças nos níveis de expressão de RNAm para COL I $(p<0,001)$, ALP $(p<0,001)$, RUNX2 $(p<0,001)$, OPN $(p<0,001)$ e OC $(p<0,001)$. As células cultivadas na superfície controle apresentaram níveis mais altos na expressão de COL I e ALP, estatisticamente diferente da expressão desses genes em 3D $(p<0,05)$ e em 3D+VB $(p<0,05)$ (Figuras 9 e 10). Para ALP também foi observada diferença significativa entre $2 D+V B$ e $3 D+V B(p<0,05)$ (Figura 10). A expressão de RUNX2 foi maior estatisticamente em 3D que em 3D+VB $(p<0,05)$ (Figura 11). O RNAm para OC foi mais expresso nas células cultivadas na superfície controle, seguidas pelas células 
no arcabouço 3D, com diferença estatística de ambos os grupos para o 3D+VB $(p<0,05)$ (Figura 13).

\section{COL I}

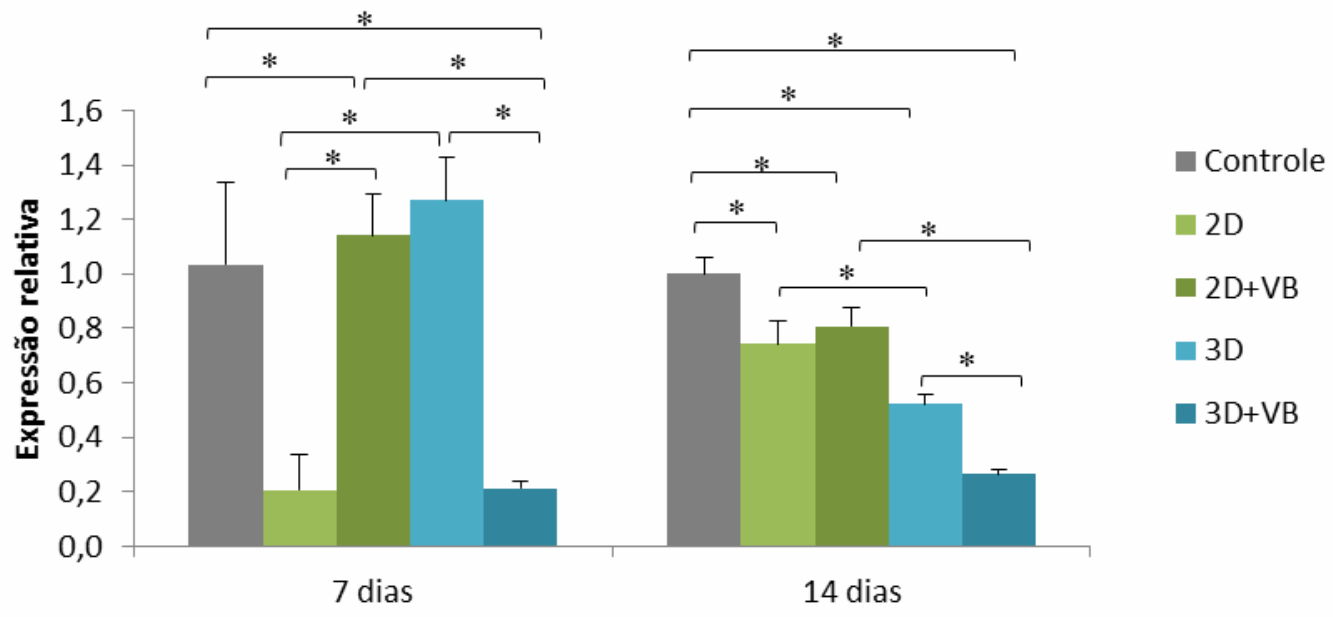

Figura 9. Expressão relativa de RNAm (média \pm desvio padrão) para Colágeno I (COL I) em culturas de células hPDLF crescidas nos diferentes grupos, avaliada aos 7 e 14 dias. Os valores foram normalizados pelo gene constitutivo $\beta$-actina e calibrados pelo controle. * indica diferença estatisticamente significante $(p<0,05)$ na análise comparativa (pós-teste de Tukey) após o teste One Way ANOVA.

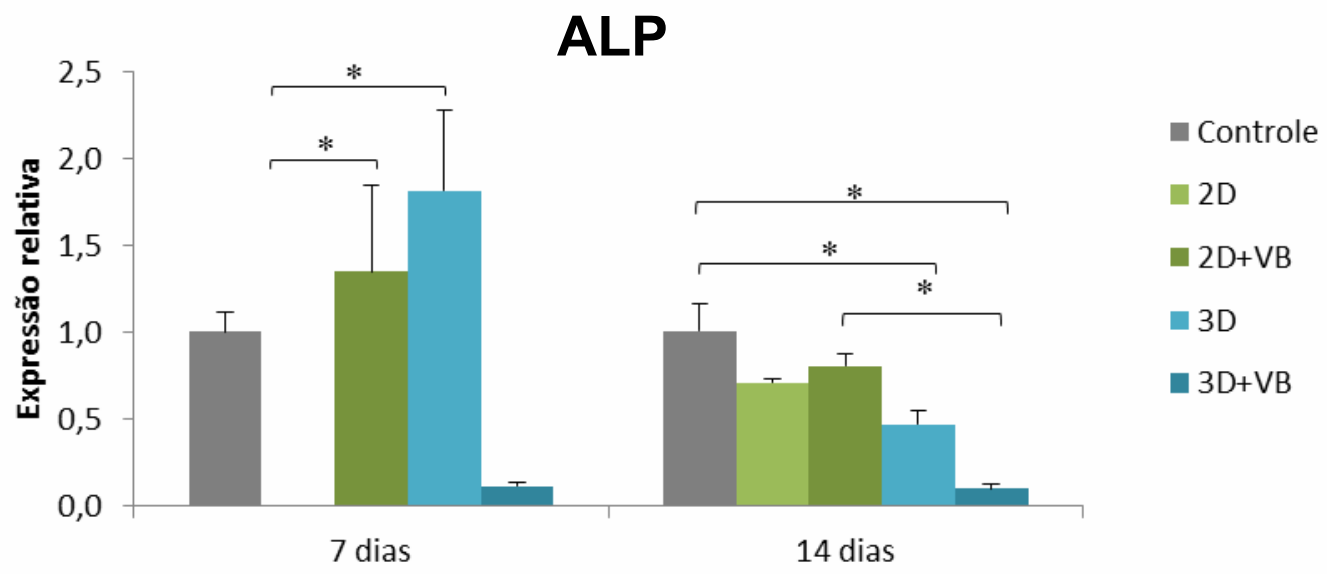

Figura 10. Expressão relativa de RNAm (média \pm desvio padrão) para Fosfatase Alcalina (ALP) em culturas de células hPDLF crescidas nos diferentes grupos, avaliada aos 7 e 14 dias. Os valores foram normalizados pelo gene constitutivo $\beta$-actina e calibrados pelo controle. * indica diferença estatisticamente significante $(p<0,05)$ na análise comparativa (pós-teste de Dunn) após o teste Kruskal-Wallis. 


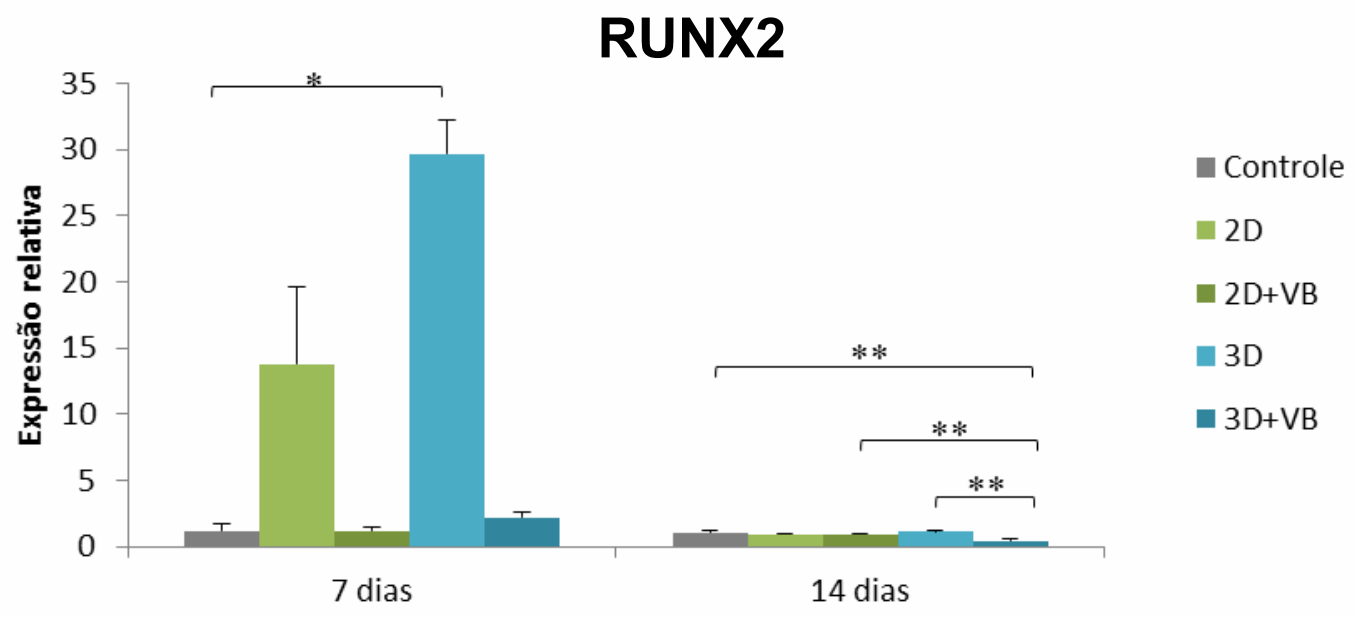

Figura 11. Expressão relativa de RNAm (média \pm desvio padrão) para RUNX2 em culturas de células hPDLF crescidas nos diferentes grupos, avaliada aos 7 e 14 dias. Os valores foram normalizados pelo gene constitutivo $\beta$-actina e calibrados pelo controle. Os valores foram normalizados pelo gene constitutivo $\beta$-actina e calibrados pelo controle. * indica diferença estatisticamente significante $(p<0,05)$ na análise comparativa (pós-teste de Dunn) após o teste Kruskal-Wallis. ${ }^{* *}$ indica diferença estatisticamente significante $(p<0,05)$ na análise comparativa (pós-teste de Tukey) após o teste One Way ANOVA.

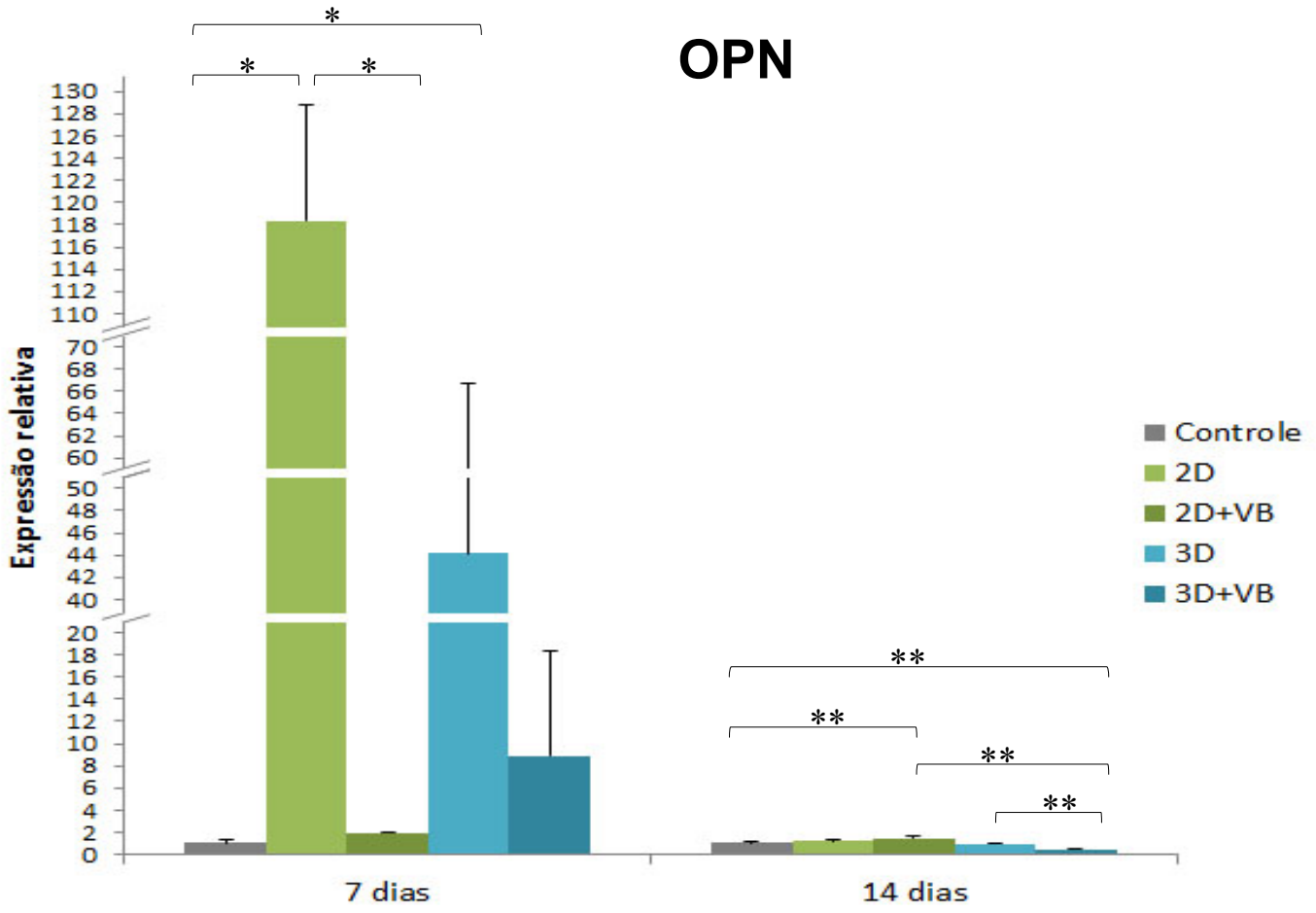

Figura 12. Expressão relativa de RNAm (média \pm desvio padrão) para Osteopontina (OPN) em culturas de células hPDLF crescidas nos diferentes grupos, avaliada aos 7 e 14 dias. Os valores foram normalizados pelo gene constitutivo $\beta$-actina e calibrados pelo controle. Os valores foram normalizados pelo gene constitutivo $\beta$-actina e calibrados pelo controle. * indica diferença estatisticamente significante $(p<0,05)$ na análise comparativa (pós-teste de Dunn) após o teste Kruskal-Wallis. ${ }^{* *}$ indica diferença estatisticamente significante $(p<0,05)$ na análise comparativa (pósteste de Tukey) após o teste One Way ANOVA. 


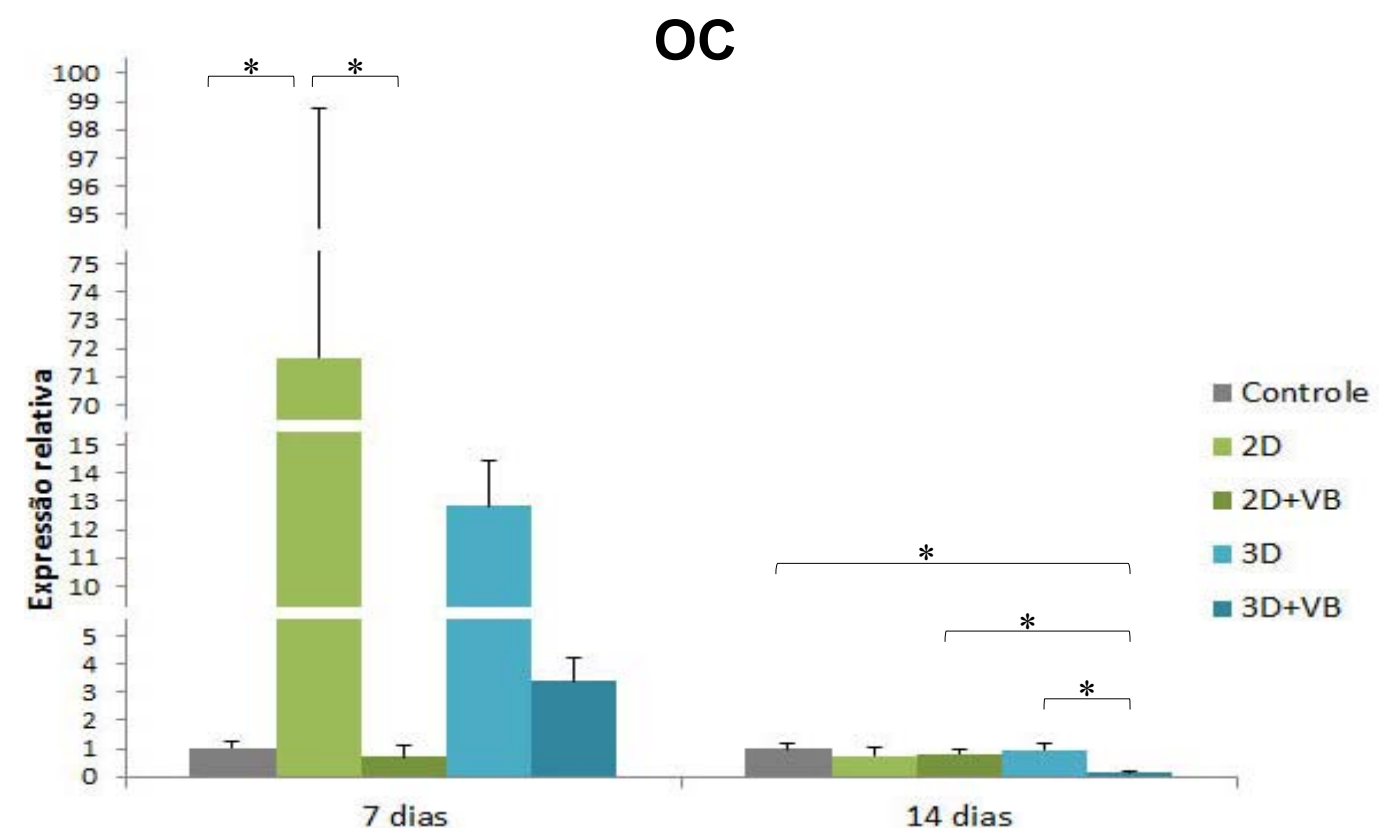

Figura 13. Expressão relativa de RNAm (média \pm desvio padrão) para Osteocalcina $(O C)$ em culturas de células hPDLF crescidas nos diferentes grupos, avaliada aos 7 e 14 dias. Os valores foram normalizados pelo gene constitutivo $\beta$-actina e calibrados pelo controle. * indica diferença estatisticamente significante $(p<0,05)$ na análise comparativa (pós-teste de Dunn) após o teste Kruskal-Wallis.

\subsubsection{Formação de matriz mineralizada}

Aos 10 dias nenhuma das culturas de hPDLFs exibiram áreas coradas por vermelho de Alizarina. Entretanto, essas marcações foram observadas aos 14 dias, as quais eram mais extensas nas culturas que continham as partículas de vidro bioativo. Através da análise microscópica, observou-se o início da formação de nódulos mineralizados independentes das partículas (Figura 14). A análise quantitativa revelou maior formação de matriz calcificada nos grupos com partículas de vidro bioativo aos 10 e 14 dias. Aos 10 dias esses resultados (2D+VB e 3D+VB) foram significativamente maiores que no controle $(p<0,05)$, em $2 D(p<0,05)$ e em 3D $(p<0,05)$; e aos 14 dias foram siginificativamente maiores que no controle $(p<0,05)$ e em 2D $(p<0,05)$ (Figura 15). 

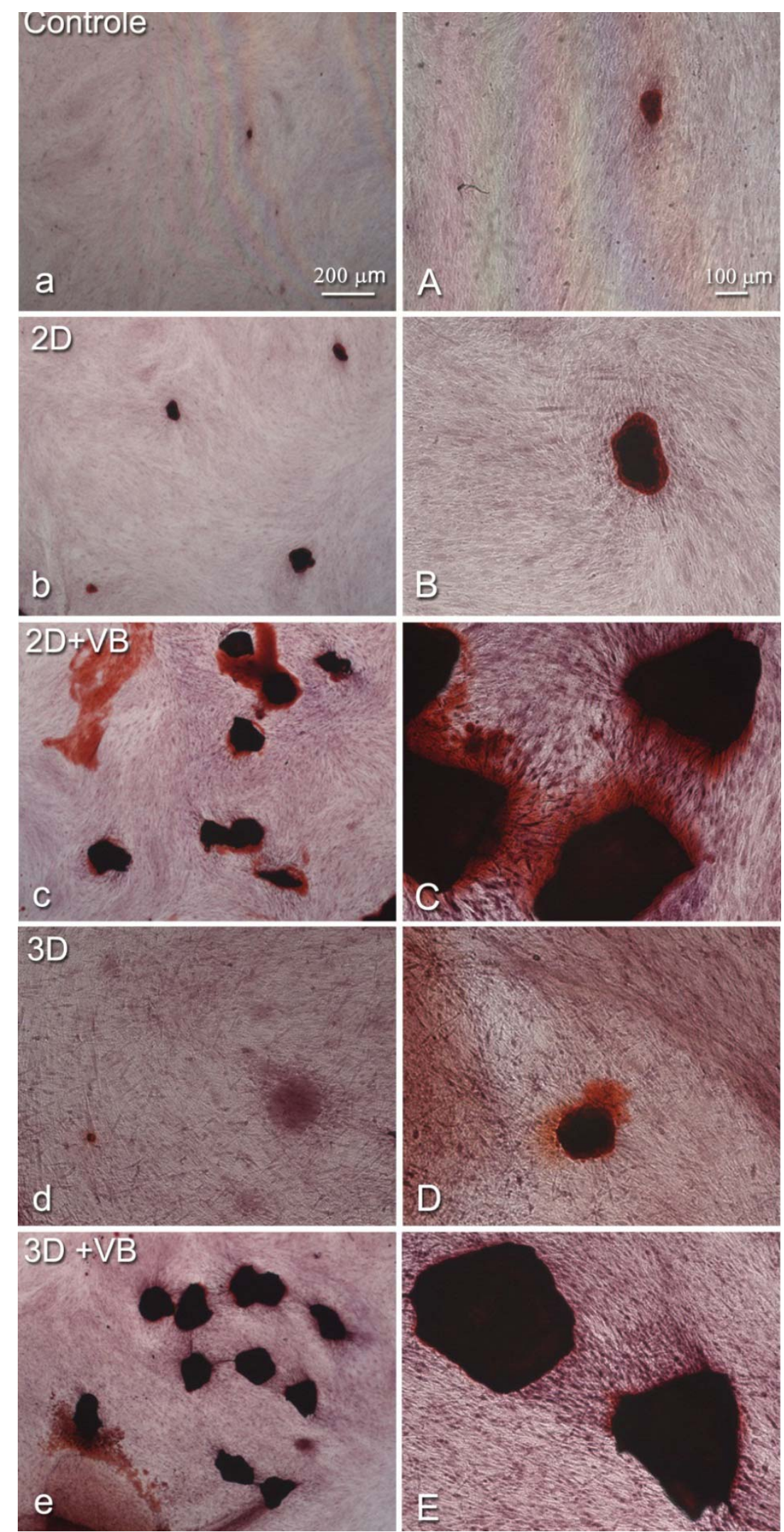

Figura 14. Aspectos microscópicos de culturas hPDLs nos diferentes arcabouços, coradas por vermelho de Alizarina, em 14 dias. A-a (Controle); B-b (2D); C-c (2D+VB); D-d (3D); E-e (3D+VB). Letras minúsculas representam a escala de $200 \mu \mathrm{m}$ e maiúsculas $100 \mu \mathrm{m}$. 


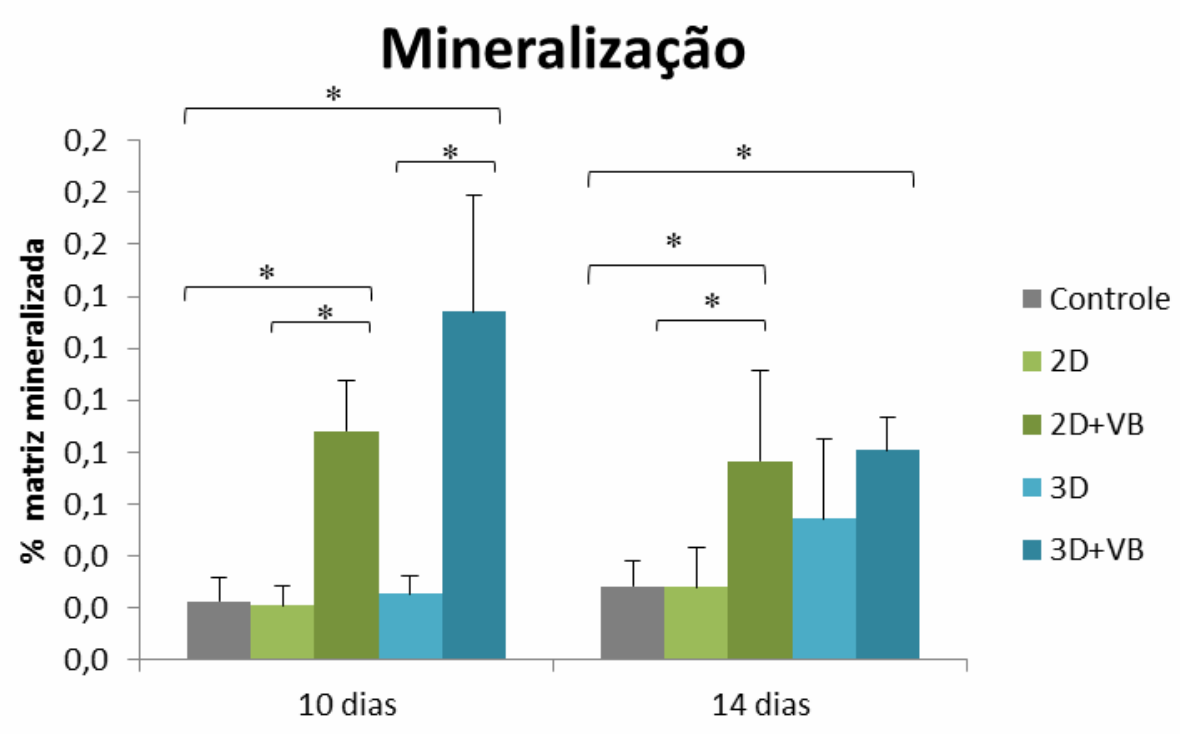

Figura 15. Formação de matriz calcificada (média \pm desvio padrão) em culturas de células hPDLF nos diferentes grupos em 10 e 14 dias. * indica diferença estatisticamente significante $(p<0,05)$ na análise comparativa (pós-teste de Dunn) após o teste Kruskal-Wallis.

\subsection{Discussão}

Os resultados desse estudo mostraram que as células do ligamento periodontal são capazes de expressar o fenótipo osteoblástico - as condições de culturas colágenas tridimensionais e partículas de vidro bioativo suportaram a viabilidade celular e contribuíram para a expressão do fenótipo osteoblástico de hPDLF, uma vez que favoreceram a atividade de ALP, formação de nódulos mineralizados e expressão gênica realcionada a esse fenótipo.

A viabilidade dos hPDLF cultivados em superfícies colágenas $2 \mathrm{D}$ e em géis colágenos $3 \mathrm{D}$ com e sem partículas de VB apresentou um índice crescente nos períodos avaliados, mostrando um índice proliferativo normal para todos os grupos. Apesar de não terem sido encontradas diferenças significantes entre os grupos aos 7 e 10 dias, as células semeadas em 3D apresentaram maiores índices de viabilidade nesses períodos. Esses resultados estão de acordo com outro estudo que demonstrou maior viabilidade celular em culturas tridimensionais quando comparada com culturas bidimensionais (Cukierman et al., 2001).

Análises morfológicas por microscopia de fluorescência mostraram que as células cultivadas nas superfícies controle, 2D e 2D+VB apresentaram o mesmo padrão de espraiamento e imunomarcações para ALP e OPN (observadas apenas aos 14 dias), sugerindo que as partículas de VB e seus produtos de dissolução iônica não exerceram influência nesses processos. A análise por microscopia 
confocal mostrou que as células estavam aderidas nas superfícies das partículas alterando a sua morfologia e discretas imunomarcações intracelulares para ALP e OPN foram observadas aos 7 e 14 dias apenas nas células em 3D. Apesar de essas marcações sugerirem a presença do fenótipo osteoblástico, a sua importância biológica é ainda desconhecida.

De acordo com a literatura, fibroblastos do ligamento periodontal devem apresentar atividade de ALP (Somerman et al., 1988; Arceo et al., 1991; Pi et al., 2007). No presente estudo os níveis da atividade de ALP foram significantemente maiores nas culturas 2D e 2D+VB comparadas com 3D e 3D+VB $(p<0,05)$ aos 7 dias. Entretanto, aos 14 dias foi observado que as células semeadas em 3D e $3 \mathrm{D}+\mathrm{VB}$ produziram níveis de atividade ALP significantemente maiores que o controle $(p<0,05)$. Uma possível explicação seria que a matriz tridimensional aos 7 dias ainda estaria intacta e estável, o que poderia ter ocasionado um atraso na atividade de fosfatase alcalina neste estágio inicial. Aos 14 dias observa-se uma contração e degradação da matriz colágena produzida pela atividade e produtos celulares, o que pode ter permitido essa maior atividade de fosfatase alcalina em um estágio mais tardio. A contração do colágeno dentro dos poços em um período mais tardio mostra-se consistente com outros estudos (Velazquez et al., 2002; Neeley et al., 2010).

Nossos resultados demonstraram que o conteúdo de cálcio foi favorecido pela presença do VB, o qual foi maior nas culturas que continham as partículas (2D+VB e 3D+VB) tanto aos 10 quanto aos 14 dias. Interessantemente, não foi observada nenhuma relação de proximidade entre os nódulos mineralizados e as partículas de VB o que sugere que os produtos iônicos gerados pelo VB é que exerceram um papel importante no processo de formação de matriz mineralizada. Essas observações estão de acordo com outros autores (Hench; Paschall, 1974; Kubo et al., 1995; Kubo et al., 1997).

Ainda de acordo com os resultados de mineralização, as culturas tridimensionais (3D e 3D+VB) apresentaram os maiores níveis de PRT aos 7 dias, gene ao qual tem disso atribuído um papel específico na formação do tecido mineralizado (Horiuchi et al., 1999). As partículas de VB também contribuíram para a expressão gênica de ALP e COL I em culturas bidimensionais (2D+VB), em concordância com outros estudos (Xynos et al., 2001; Foppiano et al., 2007; Varanasi et al., 2009) que demonstraram que os produtos iônicos liberados pelos vidros bioativos aumentam a expressão destes 
marcadores osteogênicos, contudo isto não foi observado nas culturas 3D+VB em ambos os períodos avaliados. Além disso, as partículas de VB não favoreceram a expressão de FBM e S100A4 - marcadores de um fenótipo fibroblástico. Também não foram observadas maiores expressões de RUNX2, OPN e OC. Nas culturas tridimensionais aos 7 dias, notou-se um aumento siginificativo de PRT e RUNX2, genes mais relacionados a um fenótipo osteoblástico. Aos 14 dias, percebeu-se uma diminuição na expressão gênica de todas as proteínas, sendo que essa queda foi mais acentuada para PRT, OPN, RUNX2 e OC, apesar de ter sido observada a fomação de nódulos mineralizados neste período. Esses resultados demonstram que essa expressão mais precoce dos genes relacionados a mineralização parece ter acontecido e permitiram a mineralização nos períodos mais tardios. Resultados diferem de outros estudos com osteoblastos de calvária de ratos, células da medula óssea, linhagem de células MC3T3-E1 e células do ligamento periodontal (Choi et al., 1996; Choi et al., 2011) os quais relataram que a expressão de OC foi mantida uma vez que os nódulos de mineralização iniciaram sua formação. Acredita-se na hipótese que a diminuição da expressão de OC aos 14 dias esteja relacionada a apoptose durante a diferenciação celular. Estudos têm mostrado a ocorrência de apoptose quando a mineralização avança (Lynch et al., 1998). Quando células do ligamento periodontal foram cultivadas em meio suplementado com ácido ascórbico, $\beta$-glicerofosfato e dexametasona, os níveis de expressão de OC, OPN e BSP foram maximizados aos 14 dias e caíram aos 21 dias (Iwata et al., 2010).

A heterogeneidade na expressão de RNAm e as limitações dos dados quantificáveis obtidos pela utilização do método altamente sensível RT-PCR deve ser levado em consideração. No entanto, alguns estudos que mostraram a expressão desses genes por RT-PCR não detectou qualquer expressão de RNAm para OPN, OC e ALP por Northern blot (Nohutcu et al., 1997; Parkar et al., 1999; Ivanovski et al., 2001; Pi et al., 2007). Isto pode ser atribuído aos baixos níveis de expressão de RNAm para estas proteínas em células do ligamento periodontal humano.

Futuros estudos são necessários para validar esses modelos de culturas. Há muito ainda a ser discutido sobre a capacidade de as células do ligamento periodontal em manter as suas características fenotípicas distintas na presença de partículas de vidro bioativo e em culturas tridimensionais in vitro, o que é importante para o desenvolvimento um sistema no qual podemos estudar e manipular essas células contribuindo para bioengenharia na regeneração periodontal. 


\subsection{Artigo em Inglês}

Bioactive glass particles in bi-dimensional and three-dimensional human periodontal ligament fibroblast cultures

Luciana B Alves, DDS, MS, PhD program ${ }^{1}$

Viviane C Mariguela, BMSc, MS, PhD, Research Fellow ${ }^{1}$

Márcio F M Grisi, DDS, MS, PhD Associated Professor ${ }^{1}$

Sérgio L S Souza, DDS, MS, PhD Associated Professor ${ }^{1}$

Arthur B Novaes Jr, DDS, MS, PhD Professor ${ }^{1}$

Mario Taba Jr, DDS, MS, PhD Associated Professor ${ }^{1}$

Paulo T de Oliveira, DDS, MS, PhD Professor ${ }^{2}$

Daniela Bazan Palioto DDS, MS, PhD Associated Professor ${ }^{1}$

Corresponding author: Daniela Bazan Palioto

Department of Oral Surgery and Periodontology, University of São Paulo - School of Dentistry of Ribeirão Preto

Av. do Café - s/n, Ribeirão Preto, SP, Brazil, Zip Code 14040-904

Fax number:+55 1636024788 e-mail: dpalioto@forp.usp.br

Support: FAPESP (grant number 2009/15.525-6)

There is no conflict of interest to declare

Number of tables: 1

Number of figures: 5

Word count: 3.672

Short running title: Bioactive glass particles in 3D fibroblast culture

Sentence Summary: The bioactive glass particles influence on periodontal ligament phenotype.

\footnotetext{
${ }^{1}$ Department of Oral Surgery and Periodontology, University of São Paulo - School of Dentistry of Ribeirão Preto

${ }^{2}$ Department of Morphology, Stomatology and Physiology, University of São Paulo - School of Dentistry of Ribeirão Preto
} 
Abstract

Background: Periodontal ligament fibroblasts (hPDF) play an important role in periodontal regeneration. The purpose of this study was to evaluate the influence of bioactive glass (BG) particles in bi (2D) and three-dimensional (3D) cultures on the phenotypic characterization of human periodontal ligament fibroblast (hPDLF) in vitro.

Methods: hPDLF were seeded on 2D and 3D collagen with BG particles for up to 14 days. The following parameters were assessed: cell viability, total protein content, alkaline phosphatase (ALP) activity, immunolocalization of akaline phosphatase (ALP) and osteopontin (OPN), and Alizarin red staining mineralization. Finally, total RNA was extracted and RT-PCR was performed for osteoblastic gene analysis.

Results: Experimental cultures produced an increased rate of cell proliferation/viability in comparison with control surface. Total protein content and immunolabeling for OPN and ALP in hPDLF were increased by three-dimensional conditions, but BG particles did not show any influence at 7 and 14 days. Moreover, cells seeded on $3 D$ and $3 D+B G$ showed a significant decrease of ALP activity at 7 days, and an increase at 14 days. The expression of ALP and COL I mRNAs and calcified nodule formation in vitro were also positively affected by BG, however the particles did not influence the levels expression of Runx2, OPN and OC mRNAs.

Conclusion: 3D cultures and BG particles were able to support hPDLF viability proliferation and favored the differentiation, mineralized matrix formation and the expression of osteoblastic phenotype.

Key words: primary cell culture, collagen type I, periodontal ligament, fibroblast, bioactive glass, tissue engineering 


\section{Introduction}

Periodontal tissue engineering has emerged as a promising approach to treat the loss of periodontal tissue. Fibroblasts are predominant in the periodontal ligament (PDL) and are thought to be responsible for the homeostasis and regeneration of the PDL. These fibroblasts are multipotent cells and have the potential to differentiate into osteoblasts or cementoblasts according to the microenvironment because of their osteoblastic-like properties. ${ }^{1}$ Monolayer culture of periodontal ligament fibroblast (PDLF) is completely different environments are from three-dimensional (3D) culture in vitro ${ }^{2}$ and that in vivo. ${ }^{3}$

To simulate the three-dimensional (3D) environment of cells with extracellular matrix in vivo, researchers have been to looking for an appropriate scaffolds or carriers for cell implantation. The collagen is the most useful biomaterial that has been used for tissue engineering purposes due to its excellent biocompatibility and safety associated with its biological characteristics, such as biodegradability and weak antigenicity materials in the cell. ${ }^{4}$ Cells can readily be seeded into 3D collagen scaffolds, as sponges, membranes or gels, cultured and then introduced into a defect site to tissue repair and regeneration. ${ }^{5}$

Bioactive glass $(B G)$ is a bone repairing material that bonds strongly to bone and promotes bone growth in vivo. ${ }^{6}$ The enhanced bone growth induced by BG was the result of a multistage mechanism that began as the glass contacted physiological fluids. The first stages involved the release of $\mathrm{Na}^{+}$and $\mathrm{Ca}^{2+}$ as they exchanged $\mathrm{H}^{+}$ ions in the fluid, followed by the slow release of soluble silicon. ${ }^{6}$ These ions are believed to stimulate osteogenesis. ${ }^{7}$ In vitro, there is evidence that the ionic products of BG enhance cementoblast proliferation, ${ }^{8}$ osteoblast attachment, proliferation, differentiation, and mineralization, ${ }^{9}$ and induce differentiation of bone marrow stromal cells into mature extracellular producing osteoblasts. ${ }^{10}$ It is reasonable to suggest that BG could have a similar effect on human ligament periodontal fibroblast (hPDLF) because these cells are multipotent ${ }^{11}$ and have the potential to differentiate into osteoblasts or cementoblasts according to the microenvironment. ${ }^{12,13}$ it is also reasonable to hypothesize that an osteoblastic phenotypic expression in hPDLF in vitro could correspond to a positive in vivo response such as the promotion of mineralized tissue formation induced by the presence of bioactive glass. This study focused on evaluating the effect of BG particles on hPDLF behavior cultured on 2D 
and 3D collagen gel. Whether, the three-dimensionality, collagen and ionic product of BG particles could induce hPDLF to an osteoblastic phenotype.

\section{Materials and methods}

The hPDLF were seeded on 3D scaffolds with BG particles (3D+BG) and without particles (3D); 2D collagen surface with $B G$ particles $(2 D+B G)$ and without particles (2D); and on plastic coverslip* (control).

\section{Isolation and culture of human periodontal ligament fibroblast}

hPDLF were obtained from premolars extracted for orthodontic reasons from adult patients with clinically healthy periodontium, using explant cultures as previously described. ${ }^{14}$ Briefly, premolars were extracted, washed twice with saline, and then hPDLF fragments from the middle third of the root were curetted. After being washed, periodontal ligament tissues were cut into small pieces, plated in 25 $\mathrm{cm}^{2}$ flasks ${ }^{\star *}$ and cultured in Dulbecco's modified Eagle medium (DMEM), ${ }^{\dagger \dagger}$ containing $10 \%$ fetal bovine serum (FBS), ${ }^{\ddagger \ddagger} 50 \mathrm{mg} \mathrm{mL}^{-1}$ vancomycin, ${ }^{\S \S} 5 \mu \mathrm{g} \mathrm{mL}^{-1}$ gentamycin and $50 \mathrm{ng} \mathrm{mL}^{-1}$ fungizone. .ाT

Cultures were maintained in a humidified atmosphere with 5\% CO2 and 95\% air at $37^{\circ} \mathrm{C}$, and the medium was changed every 3 days. When confluent, cells surrounding the explants were harvested using $0.05 \%$ trypsin and $0.02 \%$ ethylenediamine-tetraacetic acid $(E D T A)^{\# \#}$ in PBS and transferred to $75 \mathrm{~cm} 2$ flasks. ${ }^{* \star *}$ Cells between passages 1-3 were seeded by the over lay method on different groups at a density of $2 \times 10^{4}$ cells per well for periods of up to 14 days in $1 \mathrm{~mL}$ of osteogenic medium a-MEM supplemented with $10 \%$ FBS, $0.3 \mathrm{mg} / \mathrm{mL}$ fungizone, $50 \mu \mathrm{g} / \mathrm{mL}$ gentamycin, $5 \mu \mathrm{g} / \mathrm{mL}$ of ascorbic acid ${ }^{\dagger \dagger \dagger}$ and $7 \mathrm{mM}$ $\beta$-glycerophosphate ${ }^{\sharp \ddagger}$ and dexamethasone $10^{7}$ $\S \S$ and maintained in a humidified

\footnotetext{
${ }^{*}$ Thermanox ${ }^{T M}$, Nunc, NY, USA

${ }^{* *}$ Fisher Scientific, PA, USA

${ }^{\dagger \dagger}$ Gibco, Invitrogen, MD, USA

和 Gibco, Invitrogen, MD, USA

$\S \S$ Acros Organics, Gell, Belgium Gibco, Invitrogen, MD, USA

शा Gibco, Invitrogen, MD, USA

\#\# Gibco, Invitrogen, MD, USA

${ }^{* * *}$ Fisher Scientific, PA, USA

tit Gibco, Invitrogen, MD, USA

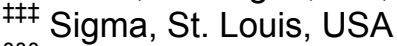

§§§ Sigma, St. Louis, USA
} 
atmosphere with $5 \% \mathrm{CO} 2$ and $95 \%$ air at $37^{\circ} \mathrm{C}$. The culture medium was changed every 2- 3 days. All procedures were approved by the Committee of Ethics in Research from the School of Dentistry of Ribeirão Preto, University of São Paulo, Brazil (n. 2009.1.1206.58.3).

\section{Preparation of scaffolds}

3D scaffolds were prepared by mixing the collagen solution $(3 \mathrm{mg} / \mathrm{ml}$, bovine Col I) ${ }^{\dagger}$ with a mixture solution of $1 \mathrm{M}$ of $\mathrm{NaOH}, 186 \mathrm{mM} \mathrm{NaHCO}$ and a-minimum essential medium ( $\alpha-M E M){ }^{\ddagger}$ The final concentration of collagen was determined to be $2 \mathrm{mg} / \mathrm{mL}$. Then, $250 \mu \mathrm{L}$ of collagen solution were placed in each well containing plastic coverslip (plate of 24 wells) ( $^{\S}$ and maintained in an incubator under a humidified atmosphere of $5 \% \mathrm{CO}_{2}$ in $95 \%$ air at $37^{\circ} \mathrm{C}$ for $15 \mathrm{~min}$, until the solution solidified into a collagen gel matrix.

2D surfaces were prepared by diluting the collagen on Phosphate Buffered Saline (PBS) ${ }^{\pi}$, for the final concentration of $50 \mu \mathrm{L} / \mathrm{mg}$. After that, $100 \mu \mathrm{L}$ of collagen dilution were placed in each well containing plastic coverslip (plate of 24 wells) and maintained at room temperature (RT) for $1 \mathrm{~h}$. After this period, the remaining solutions were aspirated.

The BG particles ${ }^{\#}$ were seeded $30 \mu \mathrm{g} /$ well 3D+BG and 2D+BG, before the gel polymerization and drying of the collagen 2D. For the control surfaces, plastic coverslips were used, considering the need to remove the film for immunofluorescence analysis.

\section{Cell Viability/Proliferation}

Cell viability/proliferation was evaluated by 3-[4,5-dimethylthiazol-2-yl]-2,5diphenyltetrazolium bromide (MTT) assay $^{15}$ at days 3,7 and 10 . Cells were incubated with $10 \%$ MTT $(5 \mathrm{mg} / \mathrm{mL})$ in culture medium at $37^{\circ} \mathrm{C}$ for $4 \mathrm{~h}$. The medium was then aspirated from the well, and $1 \mathrm{~mL}$ of acid isopropanol $(0.04 \mathrm{NHCl}$ in isopropanol) was added to each well.

\footnotetext{
${ }^{\dagger}$ BS Science, MS, USA

‡ Gibco, Invitrogen, MD, USA

$\S$ Corning Incorporated, NY, USA

I Gibco, Invitrogen, MD, USA

${ }^{\#}$ Biogran ${ }^{\circledR}$, Biomet $3 \mathrm{i}, \mathrm{FL}$, USA

Sigma, St. Louis, USA
} 
The plates were then stirred on a plate shaker for $5 \mathrm{~min}$, and $200 \mu \mathrm{L}$ of this solution was transferred to a 96-well format using opaque-walled transparentbottomed plates. ${ }^{\text {ศTाT }}$ Optical density was read at $570 \mathrm{~nm}$ on the plate reader ${ }^{\# \#}$ and data were expressed as absorbance.

\section{Total Protein Content and Alkaline Phosphatase Activity}

Total protein content was determined at 7 and 14 days by a modification of the Lowry method ${ }^{16}$. Proteins were extracted from each well with $0.1 \%$ sodium lauryl sulphate $^{* *}$ for 30 min and mixed 1:1 with Lowry solution ${ }^{* * *}$ for $20 \mathrm{~min}$ at RT. The extract was diluted in Folin and Ciocalteau's phenol reagent ${ }^{* *}$ for 30 min at RT. Absorbance was measured at $680 \mathrm{~nm}$ using a spectrophotometer. ${ }^{\mathrm{tt \dagger}}$ The total protein content was calculated from a standard curve and expressed as $\mu \mathrm{g} / \mathrm{ml}$.

Alkaline phosphatase (ALP) activity was assayed in the same lysates used for determining total protein content as the release of thymolphthalein from thymolphthalein monophosphate by using a commercial kit. ${ }^{\ddagger \neq \ddagger}$ Briefly, $50 \mu \mathrm{L}$ of thymolphthalein monophosphate were mixed with $0.5 \mathrm{~m}$ of $0.3 \mathrm{M}$ diethanolamine buffer, $\mathrm{pH} 10.1$, and left for $2 \mathrm{~min}$ at $37^{\circ} \mathrm{C}$. The solution was then added to $50 \mu \mathrm{L}$ of the lysates obtained from each well for $10 \mathrm{~min}$ at $37^{\circ} \mathrm{C}$. For color development, $2 \mathrm{~mL}$ of $0.09 \mathrm{M} \mathrm{Na} 2 \mathrm{CO} 3$ and 0.25 $\mathrm{M} \mathrm{NaOH}$ were added. After $30 \mathrm{~min}$, absorbance was measured using a spectrophotometer $^{{ }^{\dagger+\dagger}}$ at $590 \mathrm{~nm}$ and ALP activity was calculated from a standard curve using thymolphthalein to give a range from 0.012 to $0.4 \mu \mathrm{mol}$ thymolphthalein $/ \mathrm{h} / \mathrm{mL}$. Data were expressed as ALP activity normalized by total protein content.

Indirect immunofluorescence for localization of akaline phosphatase (ALP) and osteopontin (OPN)

At days 7 and 14, cells were fixed for $10 \mathrm{~min}$ at RT using $4 \%$ paraformaldehyde in $0.1 \mathrm{M}$ phosphate buffer (PB), $\mathrm{pH}$ 7.2. After washing in $\mathrm{PB}$, they were processed for immunofluorescence labeling. Briefly, cells were permeabilized with $0.5 \%$ Triton X100 in PB for 10 min followed by blocking with $5 \%$ skimmed milk in PB for 30 min.

\footnotetext{
गाTा Fisher Scientific, PA, USA

\#\#\# $\mu$ Quant Biotek Instruments, VT, USA Sigma, St. Louis, USA

${ }^{+1+\dagger} \mu$ Quant Biotek Instruments, VT, USA

$\neq \ddagger \ddagger$ Labtest Diagnostica, MG, Brazil
} 
Primary monoclonal antibodies to ALP (anti-ALP, 1:100, B4-78) $)^{\S \S \S}$ and osteopontin (anti-OPN, 1:800, MPIIIB10-1) were used, followed by a mixture of Alexa Fluor 594 (red fluorescence) - conjugated goat anti-mouse secondary antibody (1:200), TाTा

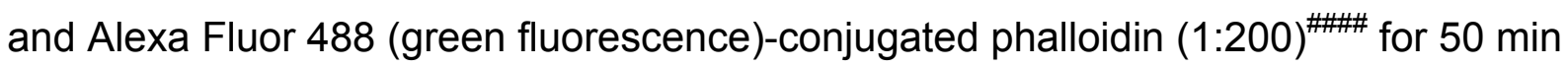
at RT in a humidified environment, for the detection of actin cytoskeleton and cell periphery. Replacement of the primary monoclonal antibody with PB was used as control. All antibody incubations were performed in a humidified environment for 60 min at RT. Between each incubation step, the samples were washed three times (5 min each) in PB. Before mounting for microscope observation, samples were briefly washed with $\mathrm{dH}_{2} \mathrm{O}$ and cell nuclei stained with DAPI $(1: 300)^{* * \star *}$ for $5 \mathrm{~min}$. After, the coverslip containing 3D collagen gel, 2D collagen and the control were carefully placed face down on glass slides and mounted with Vectashield antifade. ${ }^{\text {tttt }}$ The control and bi-dimensional samples were then examined under epifluorescence using a Leica DMLB light microscope, ${ }^{\ddagger \neq \neq \ddagger \ddagger}$ with N Plan (X10/0.25, X20/0.40) and HCX PL Fluotar (X40/0.75) objectives, outfitted with a Leica DC 300F digital camera, 1.3 Megapixel CCD. The acquired digital images were processed with Adobe Photoshop software (version 7.0). ${ }^{\S \S \S \S}$ The three-dimensional samples were examines under confocal microscopy (Leica TCS-SP2 SE laser scanning system).

Gene expression analysis using real-time PCR

At 7 and 14 days gene expression of Alkaline phosphatase (ALP), Osteopontin (OPN), Osteocalcin (OC), collagen I (COL I) and Runx2 was measured, which characterize the osteoblast phenotype genes to test whether three-dimensional conditions and bioactive particles favor the development of phenotype cells to produce mineralized matrix. For the analyses of gene expression the plating density was $4 \times 10^{4}$ cells/well on the three-dimensional scaffolds. $\beta$-actin (ACTB) was evaluated as control for constitutive gene expression. The gene expression analysis was performed by real-time PCR as described below.

\footnotetext{
$\S \S \S \S$ Developmental Studies Hybridoma Bank, lowa, USA

Developmental Studies Hybridoma Bank, lowa, USA

Пกाกा Molecular Probes, Invitrogen, MD, USA

\#\#\# Molecular Probes, Invitrogen, MD, USA

${ }^{* * * * *}$ Molecular Probes, Invitrogen, MD, USA

${ }^{t+t t+}$ Vector Laboratories, CA, USA

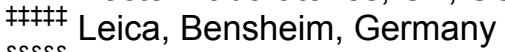

§\&\&\&\& Adobe Systems Inc., CA, USA

Leica, Bensheim, Germany
} 
Total RNA was isolated using the TRIZOL® reagent ${ }^{\text {TीTाTा }}$ according to the manufacturer's instructions. The concentration of RNA was determined by optical density at a wavelength of $260 \mathrm{~nm}$, using the GeneQuant. ${ }^{\prime \prime \# \# ~ T h e ~ R N A ~ p u r i t y ~ w a s ~}$ determined from A260/A280 (System for RT-PCR). ${ }^{* * * * *}$ Complementary DNA (cDNA) was synthesized using $1 \mu \mathrm{g}$ of RNA through a reverse transcription reaction (Highcapacity cDNA Reverse Transcription Kits). ${ }^{+t^{\dagger+\dagger}}$ Real-time PCR quantitative mRNA analyses were performed in CFX96 ${ }^{\ddagger \ddagger \neq \ddagger \ddagger ~ u s i n g ~ S y b r G r e e n ~}{ }^{\S \S \S \S \S \S}$ system. SybrGreen PCR MasterMix, specific primers and $2.5 \mathrm{ng}$ of cDNA were used in each reaction. The standard PCR conditions were $50^{\circ} \mathrm{C}(2 \mathrm{~min}), 95^{\circ} \mathrm{C}(10 \mathrm{~min})$ and 40 cycles of $15 \mathrm{~s}$ at $95^{\circ} \mathrm{C}$, and a final cycle of 20 min with increasing temperature of $60^{\circ} \mathrm{C}$ to $95^{\circ} \mathrm{C}$, followed by the standard denaturation curve. The primers used were in table 1.

Each assay was run in duplicate. For mRNA analysis, the relative level of gene expression was calculated in reference to both $\beta$-actin expression in the sample and its respective control using the cycle threshold $(\mathrm{Ct})$ method ${ }^{17}$.

\section{Mineralized bone-like nodule formation and calcium content}

At 10 and 14 days, cultures were fixed with $4 \%$ formaldehyde in $\mathrm{PB}, \mathrm{pH} 7.2$, for 2 $\mathrm{h}$ at RT and washed in the same buffer. The samples were then dehydrated in a graded series of alcohol and stained with $2 \%$ Alizarin red S, $\quad \mathrm{pH} \mathrm{4.2,} \mathrm{for} 8$ min at RT. They were visualized by epifluorescence microscopy. The quantification of color was evaluated by colorimetric method ${ }^{18}$. The absorbance was measured on a spectrophotometer ${ }^{\text {TाTानीTा }}$ at a wavelength of $405 \mathrm{~nm}$. The mineralized matrix formation was expressed as optical density.

Statistical analysis

Data presented in this work were a pool of three separate experiments in cell cultures established from three different donors. All experiments were carried out in quintuplicate $(n=5)$ with the exception of real-time RT-PCR, which was done in

\footnotetext{
ТศाTान Gibco, Invitrogen, MD, USA

Amersham Biosciences, NJ, USA

****** Invitrogen, CA, USA

${ }^{t+t t t t}$ Applied Biosystems, CA, EUA

$\ddagger \ddagger \ddagger \neq \ddagger \ddagger ~ B i o-R a d, C A$, USA

§§\&\&§ Applied Biosystems, CA, EUA

Sigma, St. Louis, USA

กाศศศा $\mu$ Quant Biotek Instruments, VT, USA
} 
triplicate $(n=3)$. Nonparametric data were submitted to Kruskal-Wallis test, for independent samples, followed by Dunn test for multiple comparisons. Parametric data were submitted to one-way analysis of variance (ANOVA) followed by a Tukey's test, which was used for multiple comparisons. SigmaStat program (version

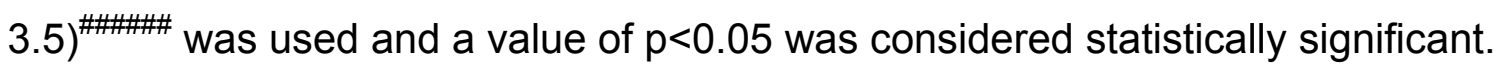

\section{Results}

\section{Cell Viability/Proliferation}

In general all groups presented an increased in viability/proliferation rate over the thime. MTT assay showed that cell viability/proliferation was affected by the culture period ( 3 day $<7$ days $<10$ days). Cultures on 2D and 3D collagen, with or without bioactive glass particles produced an increased rate of cell proliferation/viability in comparison with control surface (Fig. 1). At day 3 there was a significant difference between the groups $(p<0.001)$ and the viability of the cells was significantly higher for cultures on bi-dimensional collagens surfaces with bioactive particles (2D+BG) compared with the control surface $(p<0.05)$. Altthought there was no significance diference between groups at 7 and $1 \mathrm{a}$ days, hPDLF seeded on 3D showed the highest cell proliferation rate at these periods (Fig. 1).

\section{Total Protein Content and Alkaline Phosphatase Activity}

The 3D groups showed results showed increased the total protein content at 7 and 14 days. A significant difference of total protein content was observed when the $3 D$ and $3 D+B G$ cultures were compared with the control surface and $2 D+B G$ at 7 days. However, there was no significant difference between $2 D$ and 2D+BG and between $3 D$ and 3D+BG. The total protein content of hPDLF on 3D was significantly higher than 2D and 2D+BG ( $p<0.05)$ (Fig.1).

Higher levels of ALP activity were observed for cells on 2D and 2D+BG cultures at 7 days, which was significantly different from 3D and 3D+BG $(p<0.05)$. 3D+BG showed the lowest level of ALP activity, significantly different from the control surfaces $(p<0.05)$. However, at 14 days it was observed that the cells seeded on 3D

\#\#\#\# Statcon, Witzenhausen, Germany 
and $3 D+B G$ produced a significant higher level of ALP activity than the control surface $(p<0.05)($ Fig.1).

Indirect immunofluorescence for localization of akaline phosphatase (ALP) and osteopontin (OPN)

Epifluorescence revealed that cells were adherent and well-spread on the control, 2D and 2D+BG surfaces exhibiting a flat morphology predominantly fusiform or polygonal shapes, with a well-organized cytoskeleton, and defined actin stress fibres, shown here as green. A denser cell layer can be observed, indicating that cell proliferation has occurred (Fig.2).

ALP and OPN immunolabeling was not observed in cells on control, 2D and 2D+BG at 7 days (date not showed). The confocal microscopy revealed a natural spindle-shaped morphology and a small proportion of ALP positive was visualized mainly perinuclear and punctate deposits throughout the cytoplasm in cells seeded on 3D cultures. Noteworthy, extracellular immunolabeling was only occasionally detected around the BG particles in cells on 3D+BG. OPN was positively labeled mainly perinuclear in cells on 3D, but it was not observed in cells on 3D+BG (Fig.3).

At 14 days ALP immunolabeling was predominantly extracellular on control and 2D in a similar way, and near to the BG particles on 2D+BG (Fig.2). In cells seeded on $3 \mathrm{D}$ it was mainly perinuclear, but it was not visualized on 3D+BG (Fig.3). A perinuclear and extracellular OPN immunolabeling was occasionally detected on 2D and control surfaces, and also observed near the BG particles on 2D+BG (Fig.2). In cells seeded on 3D perinuclear and punctate deposits were visualized mainly throughout the cytoplasm, but it was not labeled in cells on 3D+BG (Fig.3).

Gene expression analysis using real-time PCR

Osteoblastic phenotype was confirmed at the transcriptional level by mRNA expression of the genes encoding COL I, ALP, Runx2, OPN and OC. BG contribute to the upregulated expression levels of ALP and COL in the cells cultured on 2D+BG, but this fact was not observed in the cells on $3 D+B G$ at both evaluated period. The levels expression of Runx2, OPN and OC were upregulated in hPDLF cells cultured on $2 \mathrm{D}, 3 \mathrm{D}$ and $3 \mathrm{D}+\mathrm{BG}$ at 7 days in comparison with those on the control surface. However, these expression levels remained upregulated in cells on $2 D$ and $2 D+B G$ 
(OPN) and on 3D (Runx2) at 14 days. The hPDLF cells cultured on all experimental groups showed the expression level of mRNA for OC downregulated in comparison with those on control surface (Fig.4).

\section{Mineralized bone-like nodule formation and calcium content}

None of the evaluated groups exhibited areas stained with Alizarin red $S$ at 10 days (data not showed). However, the cultures with BG particles showed by microscopic these stained areas and the beginning of mineralized nodule formation was observed in all groups independent of the presence of the particles examination at 14 days (Fig. 4). The cultures with bioactive particles presented greater calcium content at 10 and 14 days (Fig 1 ).

\section{Discussion}

The results showed that the periodontal ligament cells are able to express the osteoblastic phenotype - three-dimensional colagen cultures and bioactive glass particles suported the cell viability and contributed to osteoblastic phenotype expression of hPDLF, once it favored ALP activity, mineralized nodule formation and gene expression related to this phenotype.

The cell proliferation/viability rate showed a increasing on $2 \mathrm{D}$ and $3 \mathrm{D}$ collagen with or without BG up to 10 days, showing a normal proliferative index in all evaluated groups. Although no significant differences were found between the groups at 7 and 10 days, cells seeded on 3D had the highest viability levels at these periods, which is in accordance with another study that showed higher cell viability rate in three-dimensional cultures compared with two-dimensional cultures. ${ }^{19}$ It is believed that BG particles may have slightly inhibited fibroblast proliferation on $3 D+B G$ cultures when it was compared with $3 D$ at 7 and 10 days. This result is in agreement with other studies which have used BG in cell culture. ${ }^{20,21}$

Morphological analysis by fluorescence microscopy showed that cells grown on control surfaces, 2D and 2D+BG presented the same pattern of spreading and immunolabeling to ALP and OPN (observed only at 14 days), which suggests that the BG particles and their ionic dissolution products have no influence in these processes. Analysis by confocal microscopy showed cells adhered to the particles surfaces with altered morphology, and also a discrete intracellular ALP and OPN 
immunolabeling were observed at 7 and 14 days only in cells on 3D. In spite of these labelings suggesting the osteoblastic phenotype, its biological significance is still unknown.

In accordance with other earlier reports that have shown a greater ALP activity in hPDLF. ${ }^{14,22,23}$ In the present study the ALP activity level was significantly higher on $2 D$ and $2 D+B G$ than $3 D$ and 3D+BG $(p<0.05)$ However, at 14 days it was observed that the cells seeded on $3 D$ and $3 D+B G$ produced a level of ALP activity significantly higher than the control surface $(p<0.05)$. There is a hypothesis that at 7 days the three-dimensional collagen still stable and intact, and fibroblasts embedded in the collagen gel are closely surrounded by the collagen network that creates a biochemical confinement, ${ }^{24}$ which could be delay the ALP activity or withdrown at the early stage. However, at 14 days the collagen contraction and remodeling, resulted from the action of proteolytic enzymes secreted primarily by fibroblasts were observed. This may have contributed positively to the ALP activity at late stage. This contraction of the collagen complex at day 14 was consistent with the observations of other studies. ${ }^{25,26}$ Althought no significant diference has been not observed, the BG showed a positive influence in ALP activity of hPDLF cells, which is in accordance with others researches that showed that ALP activity was greater in the fibroblasts cultured with BG than in the cells grown without them. ${ }^{20,21}$

Calcium content was also favored by the presence of BG. It was higher on 2D+BG and 3D+BG culture, however no close relationship between the mineralized nodules and the particles was observed by microscopy. It suggests that BG ionic products played an important role in the formation of mineralized matrix, which is in agreement with other studies. ${ }^{21,27,28}$

In acordance with the results of mineralization, the three-dimensional cultures (3D and $3 D+B G$ ) showed the highest expression levels of PRT at 7 days, which gene has a specific role in the mineralized tissue formation. ${ }^{29}$ The BG particles also contributed to ALP and COL I gene expression on bi-dimensional cultures. This fact is in agreement with other studies ${ }^{30-32}$ which showed that the ionic products released by bioactive glasses increase the expression of osteogenic markers. However it was not observed on 3D+BG cultures in both periods evaluated. Furthermore the BG particles did not favores the gene expression of FBM and S100A4 - fibroblastic markers. Also, although OPN, OC and Runx2 expression was observed in PDL 
cells, 2, 26, 33, 34 in this study, no important expression of Runx2, OPN and OC was observed. A significative increase of PRT and Runx2 expression, which are genes related to an oeoblastic phenotype was noted in three-dimensional cultures. At 14 days, was observed a gene expression decrease of all markers, and it was more relevant for PRT, OPN, Runx2 and OC, even it was observed a mineralized nodules formation at this period. These results demonstrate that early expression of genes related to mineralization may have allowed the mineralization at later periods. These results differ from other studies with rat calvaria osteoblasts, bone marrow cells, cell line MC3T3-E1 and periodontal ligament cells, ${ }^{35,36}$ which reported that OC gene expression was maintained once mineralization nodules formation was initiated. It is believed on hypothesis that the OC expression decrease at 14 days is related to apoptosis during cell differentiation. Studies have shown the occurrence of apoptosis when mineralization advances ${ }^{37}$. When periodontal ligament cells were cultured in supplemented medium with ascorbic acid, $\beta$-glycerophosphate and dexamethasone, the expression levels of OC, OPN and BSP were maximized at 14 days and minimized at 21 days $^{38}$.

Future studies are required to validate this model of cultures. There is still much to be elucidated about the ability of the periodontal ligament cells to maintain their distinct phenotypic characteristics in the presence of BG particles on 3D culture in vitro, which is important to gives us a reliable system in which we can study and manipulate these cells to bioengineer and periodontal regeneration.

\section{Conclusions}

These results indicate the potential of hPDLF on 2D and 3D cultures with BG glass to exhibit phenotypic characteristics consistent with osteoblast-like cells. This potential was further demonstrated by ALP activity, calcified nodule formation and osteogenic genes expression. 


\section{References}

1. Fujii S, Maeda H, Wada N, Kano Y, Akamine A. Establishing and characterizing human periodontal ligament fibroblasts immortalized by SV40T-antigen and hTERT gene transfer. Cell and tissue research 2006;324:117-125.

2. Inanc $B$, Elcin AE, Elcin YM. Osteogenic induction of human periodontal ligament fibroblasts under two- and three-dimensional culture conditions. Tissue engineering 2006;12:257-266.

3. Chou AM, Sae-Lim V, Lim TM, et al. Culturing and characterization of human periodontal ligament fibroblasts - a preliminary study. . Materials Science and Engineering C 2002;20:77-83.

4. Lee $\mathrm{CH}$, Singla A, Lee Y. Biomedical applications of collagen. International journal of pharmaceutics 2001;221:1-22.

5. Xiao Y, Qian H, Young WG, Bartold PM. Tissue engineering for bone regeneration using differentiated alveolar bone cells in collagen scaffolds. Tissue engineering 2003;9:1167-1177.

6. Hench LL, Paschall HA. Direct chemical bond of bioactive glass-ceramic materials to bone and muscle. Journal of biomedical materials research 1973;7:25-42.

7. Xynos ID, Hukkanen MV, Batten JJ, Buttery LD, Hench LL, Polak JM. Bioglass 45 S5 stimulates osteoblast turnover and enhances bone formation In vitro: implications and applications for bone tissue engineering. Calcified tissue international 2000;67:321-329.

8. Carvalho SM, Oliveira AA, Jardim CA, et al. Characterization and induction of cementoblast cell proliferation by bioactive glass nanoparticles. J Tissue Eng Regen Med 2011.

9. Kaufmann EA, Ducheyne P, Shapiro IM. Effect of varying physical properties of porous, surface modified bioactive glass $45 \mathrm{~S} 5$ on osteoblast proliferation and maturation. Journal of biomedical materials research 2000;52:783-796.

10. Radin S, Reilly G, Bhargave G, Leboy PS, Ducheyne P. Osteogenic effects of bioactive glass on bone marrow stromal cells. Journal of biomedical materials research Part A 2005;73:21-29.

11. McCulloch CA, Bordin S. Role of fibroblast subpopulations in periodontal physiology and pathology. Journal of periodontal research 1991;26:144-154.

12. Gould TR, Melcher AH, Brunette DM. Migration and division of progenitor cell populations in periodontal ligament after wounding. Journal of periodontal research 1980;15:20-42.

13. McCulloch $\mathrm{CA}$, Melcher $\mathrm{AH}$. Continuous labelling of the periodontal ligament of mice. Journal of periodontal research 1983;18:231-241.

14. Somerman MJ, Archer SY, Imm GR, Foster RA. A comparative study of human periodontal ligament cells and gingival fibroblasts in vitro. Journal of dental research 1988;67:66-70.

15. Mosmann T. Rapid colorimetric assay for cellular growth and survival: application to proliferation and cytotoxicity assays. J Immunol Methods 1983;65:55-63.

16. Lowry OH, Rosebrough NJ, Farr AL, Randall RJ. Protein measurement with the Folin phenol reagent. J Biol Chem 1951;193:265-275.

17. Livak KJ, Schmittgen TD. Analysis of relative gene expression data using real-time quantitative PCR and the 2(-Delta Delta C(T)) Method. Methods 2001;25:402-408.

18. Gregory CA, Gunn WG, Peister A, Prockop DJ. An Alizarin red-based assay of mineralization by adherent cells in culture: comparison with cetylpyridinium chloride extraction. Analytical biochemistry 2004;329:77-84.

19. Cukierman E, Pankov R, Stevens DR, Yamada KM. Taking cell-matrix adhesions to the third dimension. Science 2001;294:1708-1712.

20. Kubo K, Kakimoto T, Kanda C, et al. Bioactive glass promoted formation of nodules in periodontal-ligament fibroblasts in vitro. Journal of biomedical materials research 1993;27:1175-1180. 
21. Kubo K, Tsukasa N, Uehara $\mathrm{M}$, et al. Calcium and silicon from bioactive glass concerned with formation of nodules in periodontal-ligament fibroblasts in vitro. Journal of oral rehabilitation 1997;24:70-75.

22. Arceo N, Sauk JJ, Moehring J, Foster RA, Somerman MJ. Human periodontal cells initiate mineral-like nodules in vitro. Journal of periodontology 1991;62:499-503.

23. Pi SH, Lee SK, Hwang YS, Choi MG, Kim EC. Differential expression of periodontal ligament-specific markers and osteogenic differentiation in human papilloma virus 16immortalized human gingival fibroblasts and periodontal ligament cells. Journal of periodontal research 2007;42:104-113.

24. Berthod F, Hayek D, Damour O, Collombel C. Collagen synthesis by fibroblasts cultured within a collagen sponge. Biomaterials 1993;14:749-754.

25. Velazquez OC, Snyder R, Liu ZJ, Fairman RM, Herlyn M. Fibroblast-dependent differentiation of human microvascular endothelial cells into capillary-like 3dimensional networks. FASEB journal : official publication of the Federation of American Societies for Experimental Biology 2002;16:1316-1318.

26. Neeley WW, Carnes DL, Cochran DL. Osteogenesis in an in vitro coculture of human periodontal ligament fibroblasts and human microvascular endothelial cells. Journal of periodontology 2010;81:139-149.

27. Hench LL, Paschall HA. Histochemical responses at a biomaterial's interface. Journal of biomedical materials research 1974;5:49-64.

28. Kubo K, Kamada T, Matsuyama T, et al. Characterization of nodules induced by bioactive glass on cultured periodontal-ligament fibroblasts. Journal of biomedical materials research 1995;29:503-509.

29. Horiuchi K, Amizuka N, Takeshita S, et al. Identification and characterization of a novel protein, periostin, with restricted expression to periosteum and periodontal ligament and increased expression by transforming growth factor beta. Journal of bone and mineral research : the official journal of the American Society for Bone and Mineral Research 1999;14:1239-1249.

30. Xynos ID, Edgar AJ, Buttery LD, Hench LL, Polak JM. Gene-expression profiling of human osteoblasts following treatment with the ionic products of Bioglass $45 \mathrm{~S} 5$ dissolution. Journal of biomedical materials research 2001;55:151-157.

31. Foppiano S, Marshall SJ, Marshall GW, Saiz E, Tomsia AP. Bioactive glass coatings affect the behavior of osteoblast-like cells. Acta biomaterialia 2007;3:765-771.

32. Varanasi VG, Saiz E, Loomer PM, et al. Enhanced osteocalcin expression by osteoblast-like cells (MC3T3-E1) exposed to bioactive coating glass (SiO2-CaO$\mathrm{P} 2 \mathrm{O} 5-\mathrm{MgO}-\mathrm{K} 2 \mathrm{O}-\mathrm{Na} 2 \mathrm{O}$ system) ions. Acta biomaterialia 2009;5:3536-3547.

33. Nohutcu RM, McCauley LK, Koh AJ, Somerman MJ. Expression of extracellular matrix proteins in human periodontal ligament cells during mineralization in vitro. Journal of periodontology 1997;68:320-327.

34. Ivanovski S, Haase HR, Bartold PM. Expression of bone matrix protein mRNAs by primary and cloned cultures of the regenerative phenotype of human periodontal fibroblasts. Journal of dental research 2001;80:1665-1671.

35. Choi JY, Lee $\mathrm{BH}$, Song KB, et al. Expression patterns of bone-related proteins during osteoblastic differentiation in MC3T3-E1 cells. Journal of cellular biochemistry 1996;61:609-618.

36. Choi MH, Noh WC, Park JW, Lee JM, Suh JY. Gene expression pattern during osteogenic differentiation of human periodontal ligament cells in vitro. Journal of periodontal \& implant science 2011;41:167-175.

37. Lynch MP, Capparelli C, Stein JL, Stein GS, Lian JB. Apoptosis during bone-like tissue development in vitro. Journal of cellular biochemistry 1998;68:31-49.

38. Iwata T, Yamato M, Zhang Z, et al. Validation of human periodontal ligament-derived cells as a reliable source for cytotherapeutic use. Journal of clinical periodontology 2010;37:1088-1099. 


\section{Tables}

Table 1. Primer Sequences for Real-Time Polymerase Chain Reaction

\begin{tabular}{|c|c|c|}
\hline \multirow{3}{*}{$\begin{array}{l}\text { Genes } \\
\text { B-actin }\end{array}$} & \multicolumn{2}{|r|}{ Primer sequences } \\
\hline & Forward & 5'-ATGTTTGAGACCTTCAACA-3' \\
\hline & Reverse & 5'-CACGTCAGACTTCATGATGG-3' \\
\hline \multirow{2}{*}{ RUNX2 } & Forward & 5'-TATGGCACTTCGTCAGGATCC-3' \\
\hline & Reverse & 5'-AATAGCGTGCTGCCATTCG-3' \\
\hline \multirow{2}{*}{ COL I } & Forward & 5'-TGACGAGACCAAGAACTG-3' \\
\hline & Reverse & 5'-CСАТССАAАCСАСТGAAACC-3' \\
\hline \multirow{2}{*}{ ALP } & Forward & 5'ACGTGGCTAAGAATGTCATC-3' \\
\hline & Reverse & 5'-CTGGTAGGCGATGTCCTTA-3' \\
\hline \multirow{2}{*}{ OPN } & Forward & 5'-AGACACATATGATGGCCGAGG-3' \\
\hline & Reverse & 5'-GGCCTTGTATGCACCATTCAA-3' \\
\hline \multirow{2}{*}{ OC } & Forward & 5'-CAAAGGTGCAGCCTTTGTGTC-3' \\
\hline & Reverse & 5'-TCACAGTCCGGATTGAGCTCA-3' \\
\hline
\end{tabular}

\section{Figure legends}

Fig. 1 - A - Cell viability (means $\pm S D$ ) at 3, 7 and 10 days; B - Calcium content (means $\pm S D$ ) at 10 and 14 days; C - Total protein content (means $\pm S D$ ) at 7 and 14 days; D - ALP Activity (means $\pm S D$ ) at 7 and 14 days. ${ }^{*} p<0.05$ (Kruskal-Wallis Pos-test Dunn's) and ${ }^{* *} p<0.05$ (ANOVA - Pos-test Tukeys's)

Fig. 2 - hPDL cells grown on different bidimensional surfaces (control, 2D and 2D+BG) at 14 days. Epifluorescence of actin cytoskeleton labeling (phalloidin labeling, green fluorescence), DNA stain (DAPI, blue fluorescence), ALP (A-C) and OPN (D-F) red fluorescence. Bar A-C: $200 \mu \mathrm{m}$ and Bar D-F: 100 $\mu \mathrm{m}$

Fig. 3 - hPDL cells grown on different threedimensional surfaces (3D and 3D+BG) at 7 days $(A, C, E$ and $G$ ) and 14 days ( $B, D, F$ and $H$ ). Fluorescence of actin cytoskeleton labeling (phalloidin labeling, green fluorescence), DNA stain (DAPI, blue fluorescence), ALP (A-D) and OPN (E-H) red fluorescence observed in confocal microscopy. 
Fig. 4 - Gene expression of COL I, ALP, Runx2, OPN and OC in hPDLF cultured on different groups at 7 and 14 days using real-time PCR. Data were calculated as the relative expression of the target mRNA normalized to $\beta$-actin and to control (calibrator) and are reported as mean $\pm S D$. ${ }^{*} p<0.05$ (Kruskal-Wallis - Pos-test Dunn's) and ${ }^{* *} p<0.05$ (ANOVA - Pos-test Tukeys's).

Fig. 5 - Alizarin red staining showed limited amounts of mineralized nodule formation in hPDLF cultures. Control ( $a$ and A), 2D ( $b$ and B), 2D+BG ( $c$ and $C$ ), 3D ( $d$ and $D)$ and 3D+BG (e and E). Bar a-e: $200 \mu \mathrm{m}$ and Bar A-E: 100 $\mu \mathrm{m}$ 
6. Capítulo II 
No capítulo II, foram considerados os resultados dos experimentos com células osteogênicas da calvária de ratos recém-nascidos.

\subsection{Resultados}

De forma geral, todos os grupos mostraram uma viabilidade celular crescente de acordo com os períodos avaliados. O ensaio colorimétrico MTT revelou que todos os grupos diferenças significantes na viabilidade das células crescidas nas diferentes superfícies e arcabouços avaliados apenas aos 7 dias $(p<0,001)$, no qual as células cultivadas em 3D+VB e 3D exibiram menores índices de viabilidade. Diferenças significativas foram observadas quando $3 \mathrm{D}+\mathrm{VB}$ foi comparado aos grupos $2 \mathrm{D}+\mathrm{VB}$ $(p<0,05)$ e controle $(p<0,05)$. Aos 3 e 10 dias a viabilidade celular foi semelhante, não havendo diferenças significativas entre os grupos avaliados (Figura 16).

\section{Viabilidade Celular}

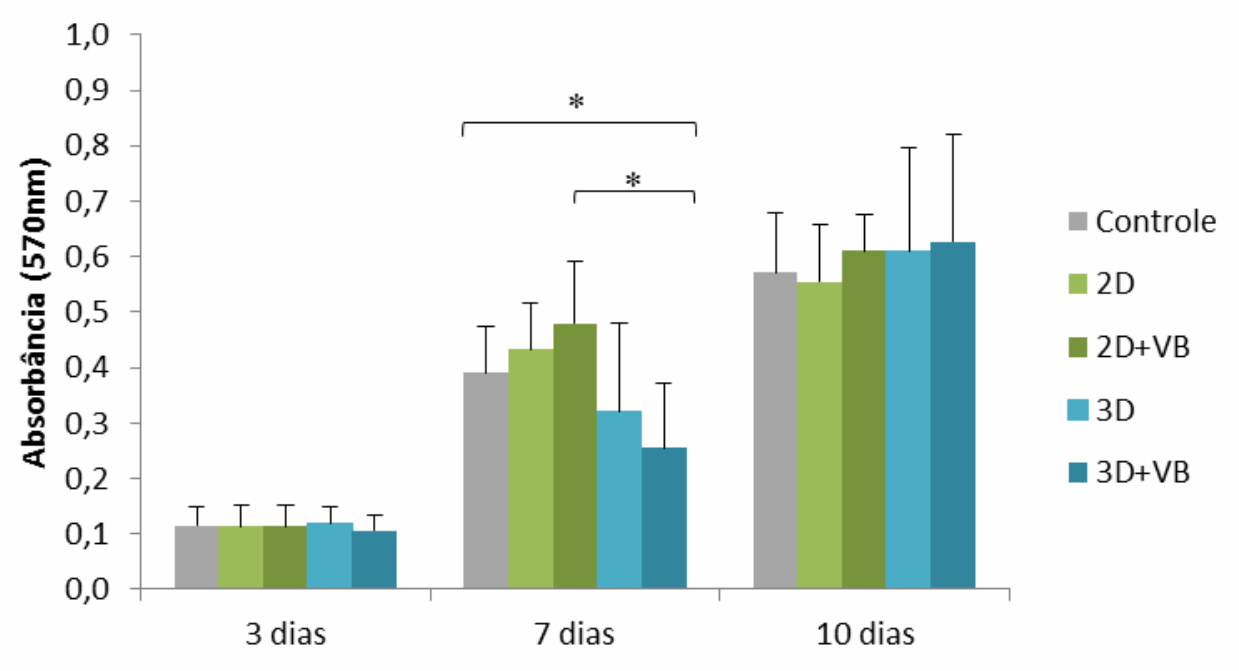

Figura 16. Viabilidade celular (média \pm desvio padrão, em densidade óptica) de culturas de células osteogênicas crescidas na superfície controle e nos diferentes arcabouços, determinada pelo ensaio colorimétrico MTT, em 3, 7 e 10 dias. ${ }^{*}$ indica diferença estatisticamente significante $(p<0,05)$ na análise comparativa (pós teste de Tukey) após o teste One Way ANOVA.

\subsubsection{Conteúdo de proteína total}

O conteúdo de proteína total que foi determinado usando o método de Lowry apresentou diferenças significantes nos diferentes grupos avaliados aos $7(p=0,001)$ e 14 dias $(p<0,001)$. O conteúdo de proteína total foi significantemente maior nas culturas 3D+VB comparadas ao controle e 2D+VB em 7 dias e 14 dias. Diferenças 
significantes também foram encontradas comparados 3D e 2D aos 14 dias (Figura 17).

\section{Conteúdo de Proteína Total}

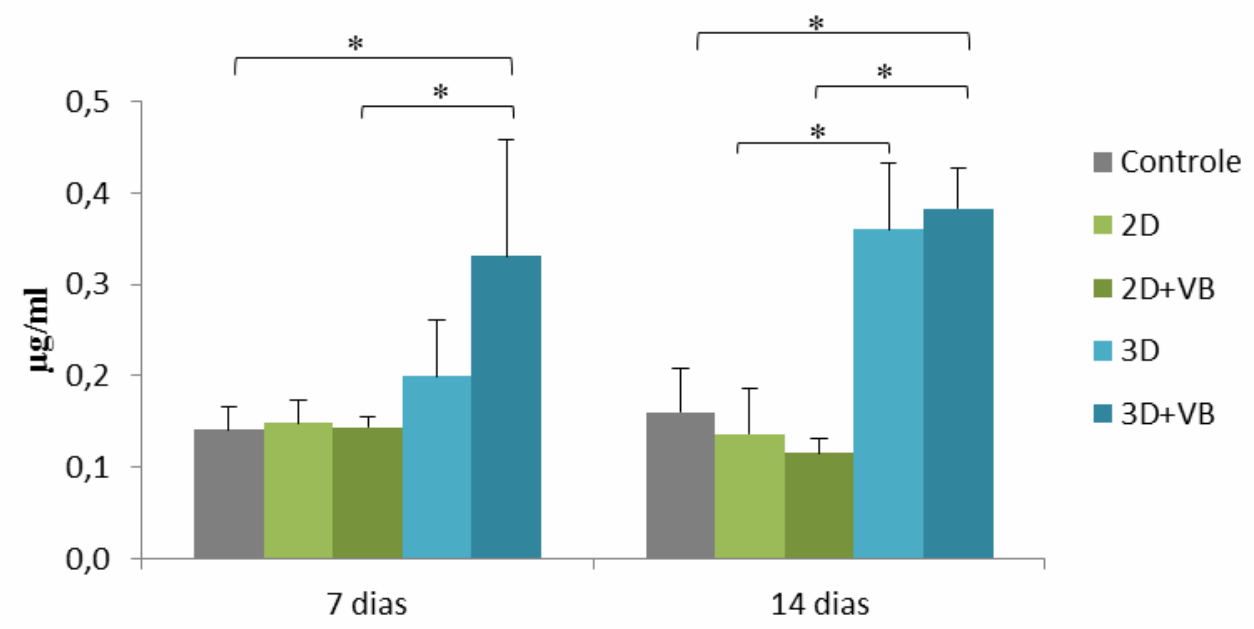

Figura 17. Medida do conteúdo de proteína total (média \pm desvio padrão, em densidade óptica) de culturas de células osteogênicas crescidas na superfície controle e nos diferentes arcabouços, expressa como $\mu \mathrm{g} / \mathrm{ml}$, em 7 e 10 dias. * indica diferença estatisticamente significante $(p<0,05)$ na análise comparativa (pós teste de Dunn) após o teste Kruskal-Walis.

\subsubsection{Atividade de fosfatase alcalina}

Os resultados revelaram diferenças significantes na atividade de fosfatase alcalina nos diferentes grupos avaliados aos 7 e 14 dias $(p<0,001)$. Aos 7 dias a atividade de ALP foi maior nas culturas que continham as partículas de vidro bioativo $(2 D+V B$ e $3 D+V B)$. Diferenças significantes foram encontradas entre $2 D$ e 2D+VB $(p<0,05)$ e entre 3D e 3D+VB $(p<0,05)$. A atividade de ALP das células em 3D+VB foi significante maior que na superfície controle $(p<0,05)$. Aos 14 dias, 3D e 3D+VB apresentaram os menores valores de atividade de ALP, sendo a significantemente diferentes de $2 \mathrm{D}(p<0,05)$ e 2D+VB $(p<0,05)$ (Figura 18). 


\section{Atividade de Fosfatase Alcalina}

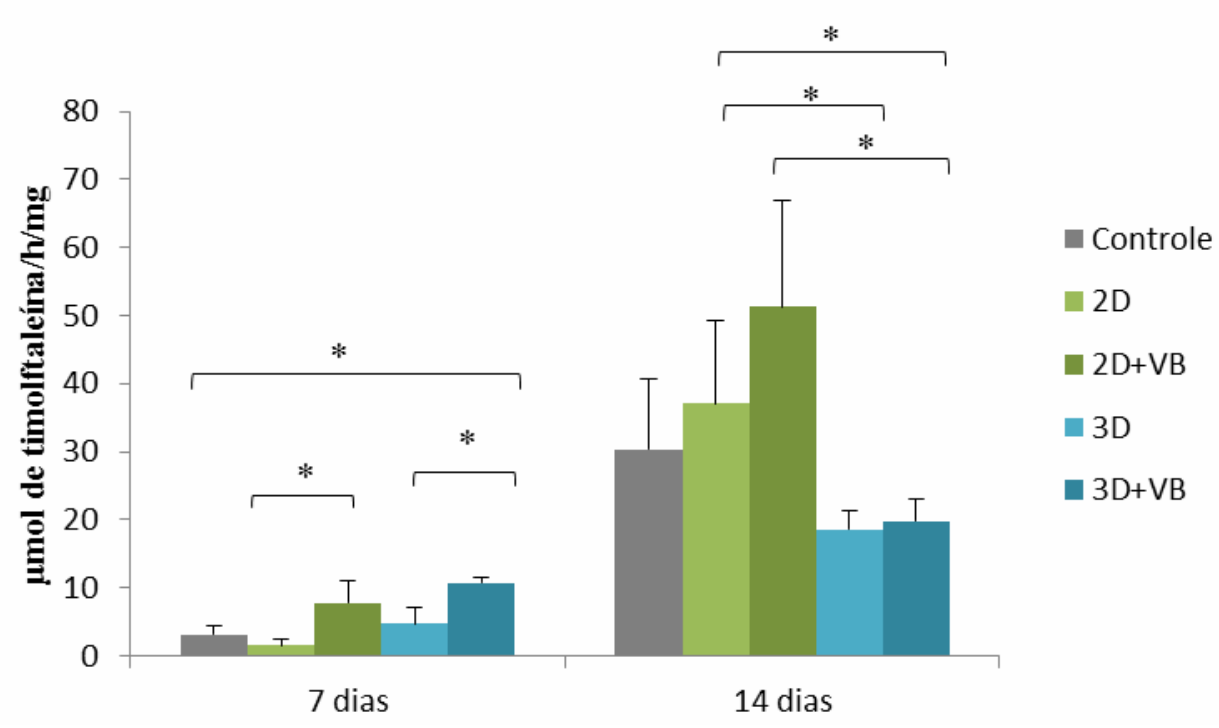

Figura 18. Medida da atividade de fosfatase alcalina (média \pm desvio padrão, em densidade óptica) de culturas de células osteogênicas crescidas na superfície controle e nos diferentes arcabouços, expressa como $\mu \mathrm{mol}$ de timolftaleína/h/mg, em 7 e 10 dias. * indica diferença estatisticamente significante $(p<0,05)$ na análise comparativa (pós teste de Dunn) após o teste Kruskal-Wallis.

\subsubsection{Localização de proteínas da matriz extracelular não-colágena por imunofluorescência indireta}

Foi realizada a imunolocalização de proteínas da matriz extracelular nãocolágena: osteopontina (OPN) e sialoproteína óssea (BSP) nas culturas com células osteogênicas da calvária de ratos recém-nascidos no período de 7 dias.

As células nas culturas bi-dimensionais (2D, 2D+VB e controle) apresentavam forma achatada ou poligonal, com um citoesqueleto bem organizado, e fibras de stress de actina definidas, mostrado aqui em verde. Uma camada de células mais densa pode ser observada, indicando que a proliferação celular ocorreu. Imunomarcações positivas para OPN e BSP nas células, por epifluorescência foram visualizadas principalmente através de depósitos perinucleares e em alguns pontos no citoplasma das células. Não foi observada nenhuma relação dessas marcações com a presença das partículas (Figura 19).

Nas culturas tridimensionais, as células apresentavam um aspecto mais estrelado e alongado, também com um citoesqueleto bem organizado, e fibras de stress de actina definidas, mostrado aqui em verde. Imunomarcação positiva para OPN principalmente ao redor dos núcleos e para BSP em grande parte do citoplasma próxima ao núcleo das células em 3D. Entretanto estas marcações não 
foram observadas em células no grupo com as partículas (3D+VB). Apenas, pouca ou nenhuma marcação na superfície das partículas (Figura 20).

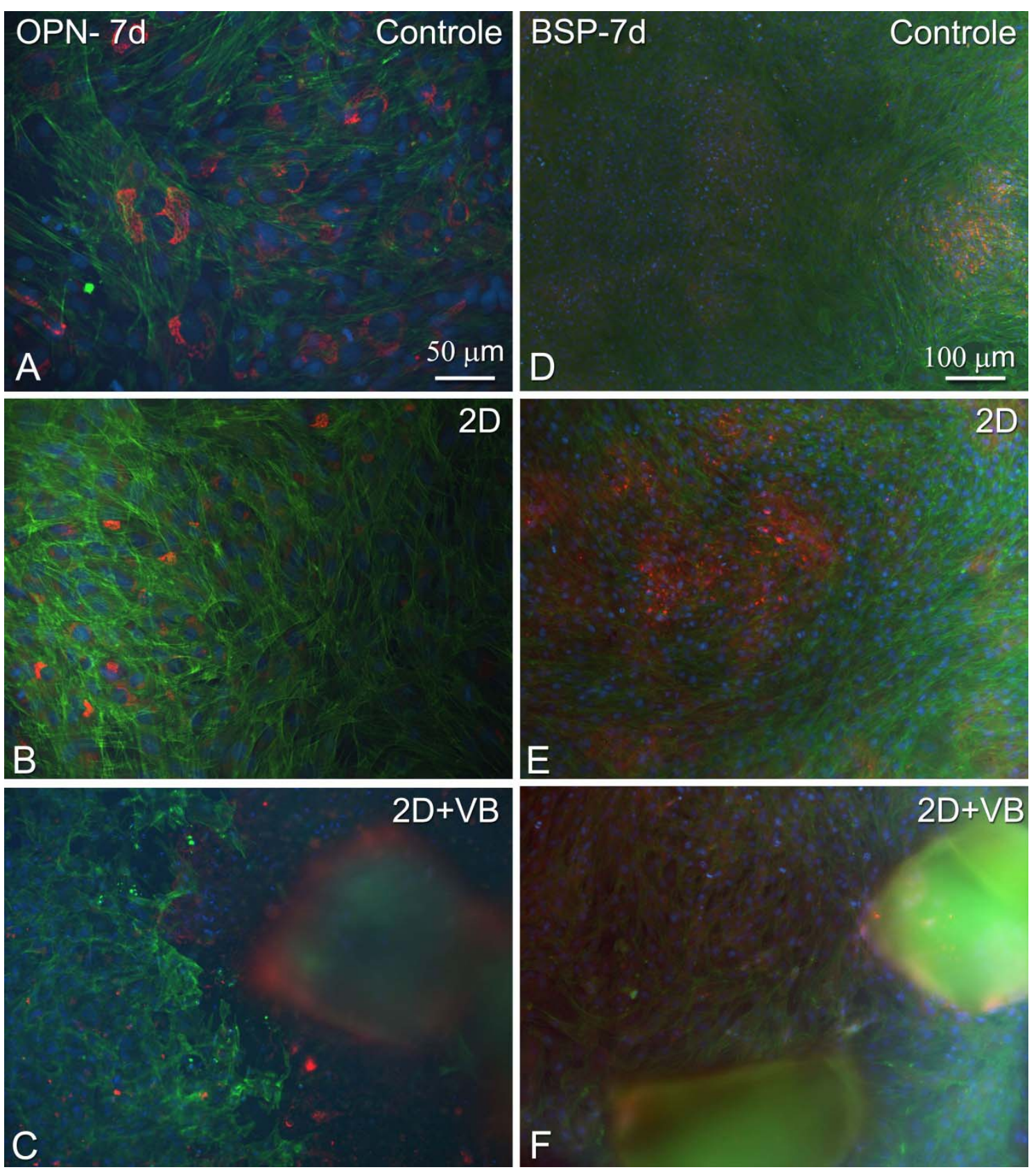

Figura 19. Epifluorescência de culturas de células osteogênicas da calvária de ratos recém-nascidos crescidas sobre as diferentes superfícies bidimensionais no período de 7 dias. Marcação em vermelho indica OPN em A-C (escala $50 \mu \mathrm{m}$ ) e BSP em D-F (escala $100 \mu \mathrm{m}$ ). Fluorescência verde revela citoesqueleto de actina em $A-F$, enquanto que a azul, os núcleos celulares (A-F). 


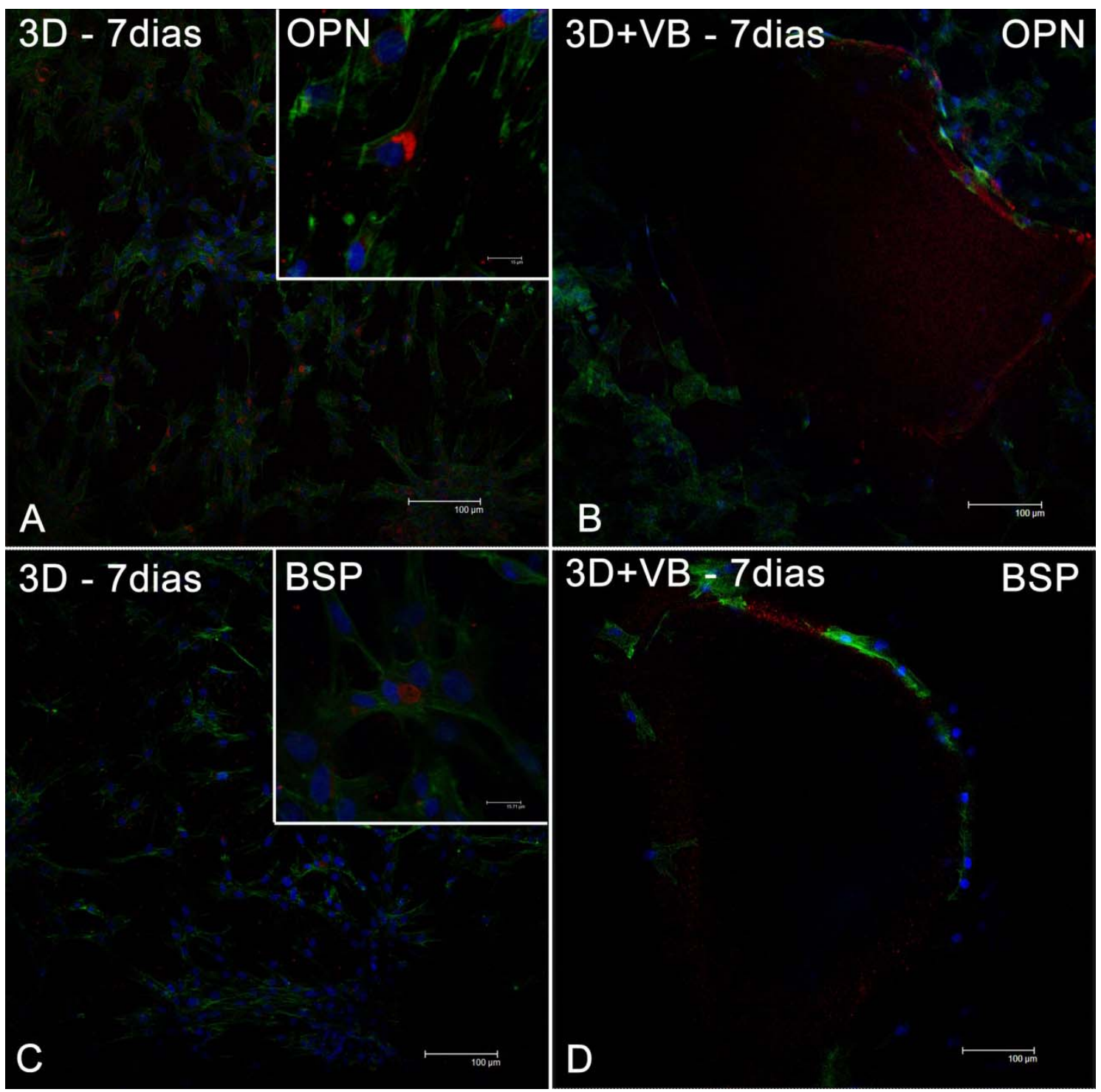

Figura 20. Microscopia confocal de culturas de células osteogênicas da calvária de ratos recémnascidos crescidas sobre os arcabouços tridimensionais 3D (A-C) e 3D+VB (B-D). Marcação em vermelho indica OPN (A-B) e BSP (C-D) em 7 dias. Fluorescência verde revela citoesqueleto de actina e florescência azul, os núcleos celulares (A-D).

\subsubsection{Expressão quantitativa dos genes por reação em cadeia da polimerase} em tempo real (Real-time PCR)

Os ensaios de RT-PCR mostraram diferenças nos níveis de expressão de todos os genes avaliados: COL I $(p<0,001)$, ALP $(p<0,001)$, OPN $(p<0,001)$ e OC $(p<0,001)$, exceto RUNX2 e BSP.

ALP, COL I e RUNX2 apresentaram maiores níveis de expressão nas culturas tridimensionais (3D e 3D+VB) e OPN, OC e BSP exibiram níveis mais altos de expressão gênica em 2D+VB. A expressão de COL I foi significativamente maior em $3 \mathrm{D}+\mathrm{VB}$ quando comparada com 2D+VB. Entretanto as células em 2D+VB 
apresentaram níveis de expressão de OPN e OC estatisticamente maiores que em 2D e 3D+VB, nos quais a expressão desses genes e de BSP estavam downregulated em relação ao grupo controle (Figura 21).

ALP

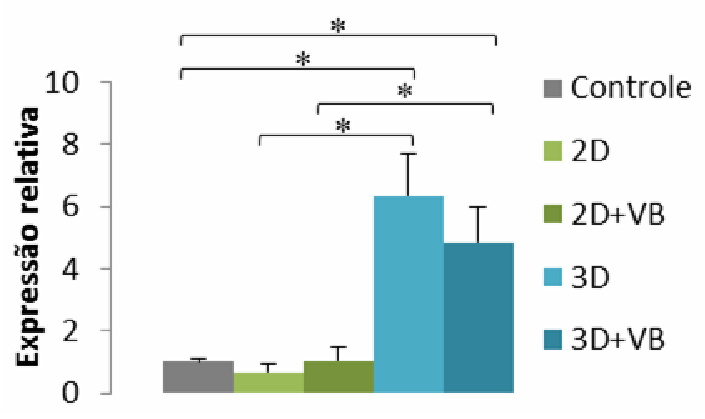

RUNX2
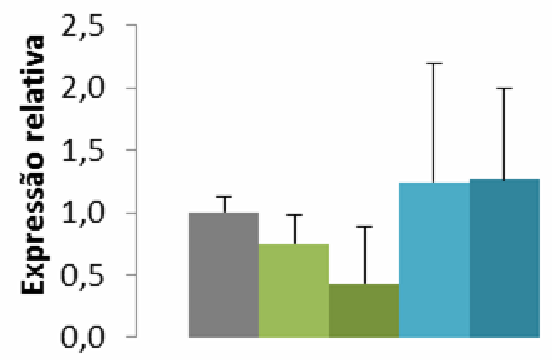

controle

2D

$2 \mathrm{D}+\mathrm{VB}$

$\square 3 \mathrm{D}$

- 3D+VB

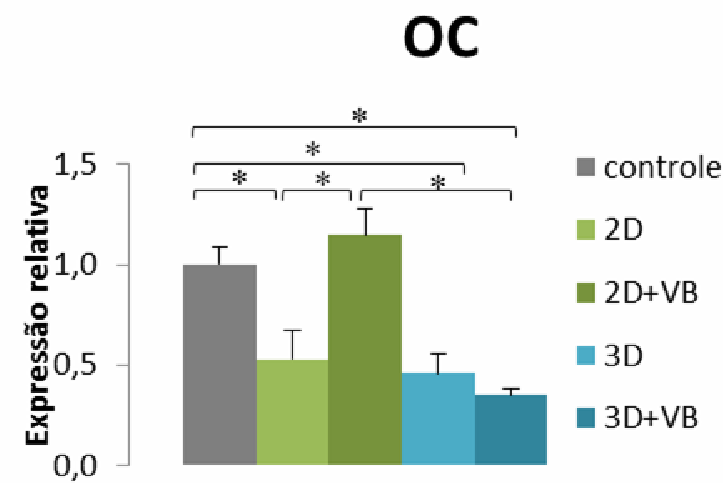

COLI

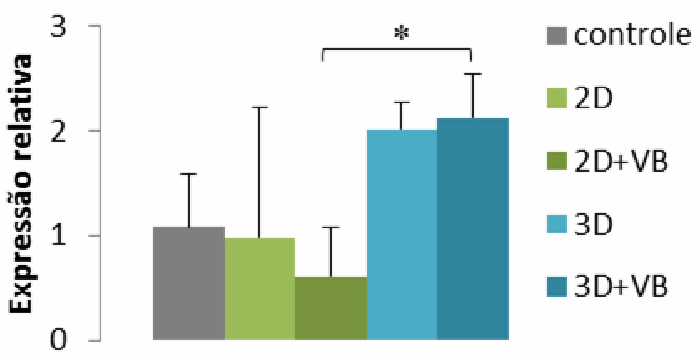

BSP

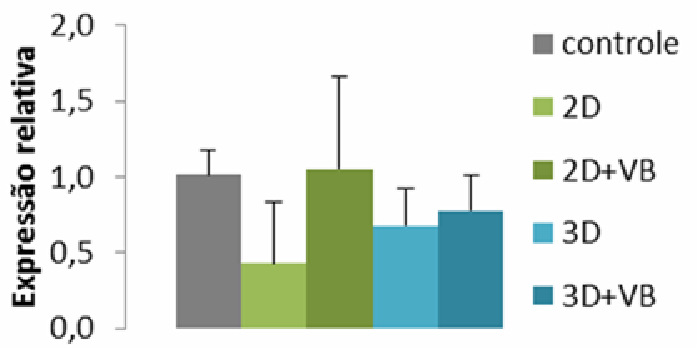

Figura 21. Expressão relativa de RNAm (média \pm desvio padrão) para os genes marcadores do fenótipo osteoblástico Colágeno I (COL I), Fosfatase Alcalina (ALP), RUNX2, Sialoproteína Óssea (BSP), Osteocalcina (OC) e Osteopontina (OPN) em culturas de células osteogênicas crescidas nos diferentes gupos, avaliada aos 7 dias. Os valores foram normalizados pelo gene constitutivo $\beta$-actina e calibrados pelo controle. 


\subsubsection{Formação de Matriz mineralizada}

Aos 10 e 14 dias as culturas de células osteogênicas exibiram áreas coradas por vermelho de Alizarina todos os grupos. Estas áreas apresentavam-se mais extensas nos grupos que continham as partículas de VB. A análise quantitativa revelou maior quantidade de matriz calcificada nos grupos com partículas de VB aos 10 e 14 dias. Aos 10 dias a quantidade de cálcio foi significativamente maior em 3D+VB comparado ao controle ( $p<0,05)$; e em 2D+VB comparado ao 2D $(p<0,05)$ e controle $(p<0,05)$. Aos 14 dias a formação de matriz calcificada também foi significativamente maior em 3D+VB comparado ao controle $(p<0,05)$, em 2D+VB quando comparado com 2D e em 3D comparado com 2D ( $p<0,05)$ (Figura 22). Através da análise microscópica observou-se o inicio da formação de nódulos mineralizados independentes das partículas em todos os grupos (Figura 23).

\section{Mineralização}

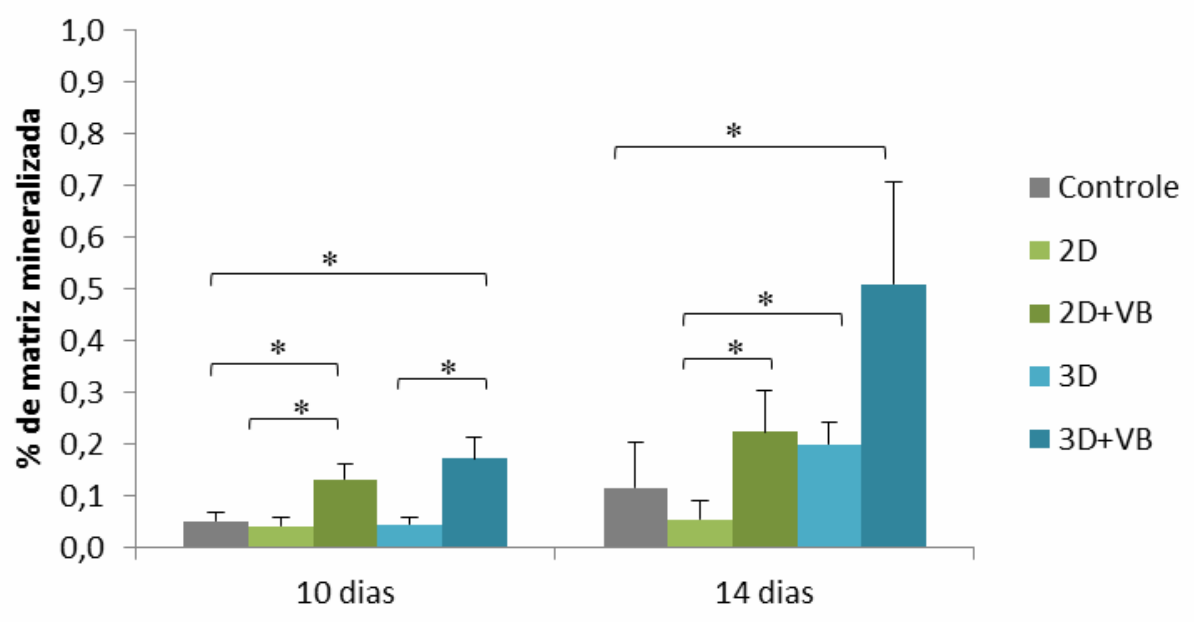

Figura 22. Formação de matriz calcificada (média \pm desvio padrão) em culturas de células osteogênicas nos diferentes arcabouços em 10 e 14 dias. * indica diferença estatisticamente significante $(p<0,05)$ na análise comparativa (pós-teste de Dunn) após o teste Kruskal-Walis. 

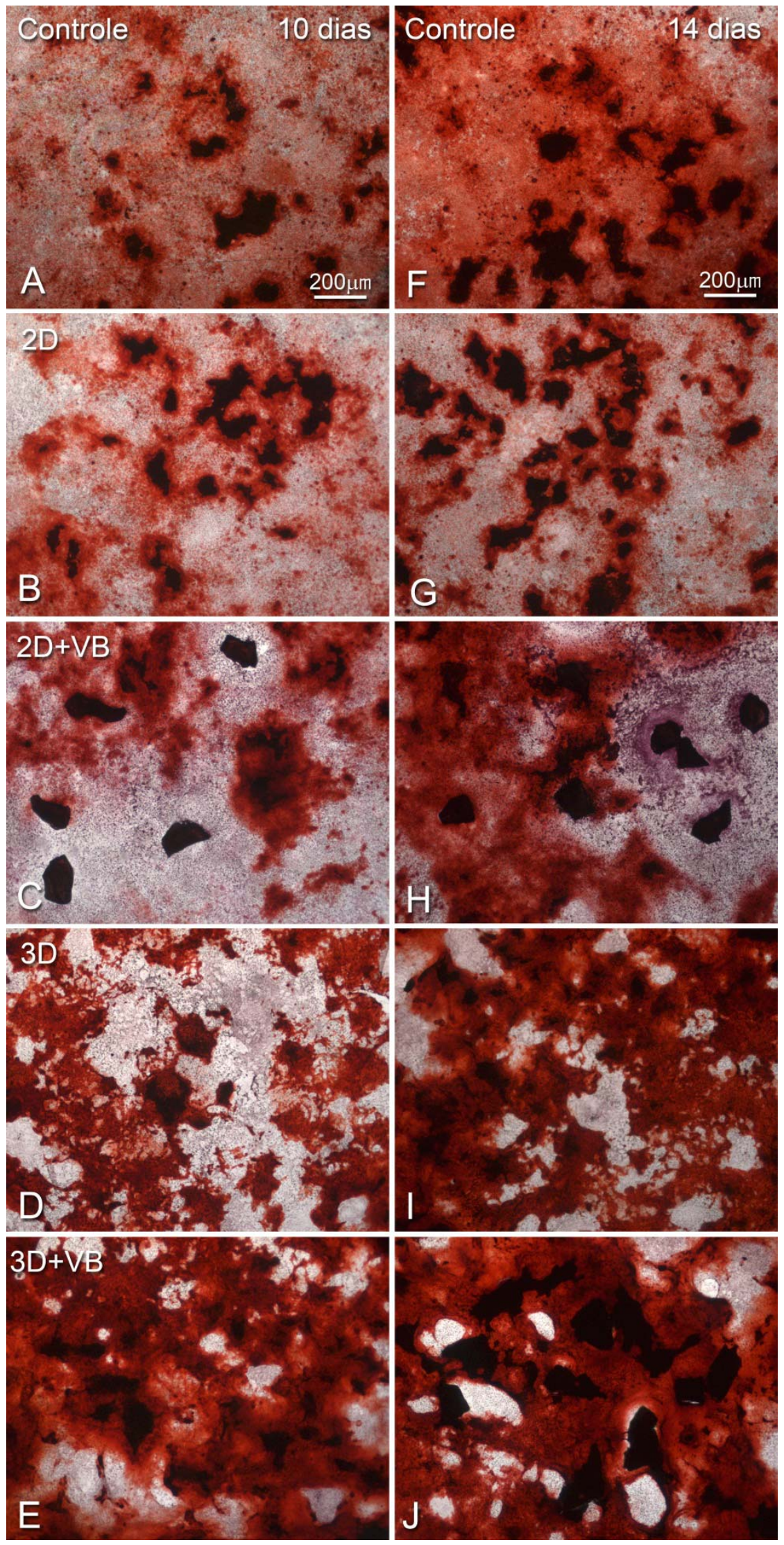

Figura 23. Aspectos microscópicos de culturas osteogênicas nos diferentes arcabouços, coradas por vermelho de Alizarina, em 10 dias (A, B, C, D e E) e14 dias (F, G, H, I e J) em escala de $200 \mu \mathrm{m}$. 


\subsection{Discussão}

O presente estudo avaliou a influência das partículas de VB em células osteogênicas derivadas de calvária de ratos recém-nascidos em culturas 2D e 3D. Nossos resultados demonstraram que a tridimensionalidade e as partículas de VB suportaram a viabilidade e diferenciação celular, atividade de ALP, formação de nódulos mineralizados e possibilitaram a expressão de um fenótipo osteoblático.

Todos os grupos apresentaram crescimento no índice de viabilidade no decorrer dos períodos analisados. Contudo, a tridimensionalidade, de alguma forma, interferiu negativamente nesses resultados no período de 7 dias, corroborando outros estudos nos quais as células ósseas apresentaram maiores índices de viabilidade e proliferação quando cultivadas sobre substratos 2D que em colágeno 3D (Fernandes et al., 2009; Naito et al., 2011). Isto pode ser explicado devido à organização estrutural da matriz extracelular circundante, a qual pode ter diminuído a viabilidade das células (Riccio et al., 2010; Ozawa et al., 2003). Por outro lado, as partículas de VB favoreceram a viabilidade celular na superfície 2D+VB, o que também está de acordo com outros estudos in vivo e in vitro os quais demonstraram que as partículas de VB contribuem para o aumento da viabilidade e proliferação de osteoblastos (Loty et al., 2001; Sun et al., 2007; Au et al., 2010). Diferenças significativas não foram encontradas entre os grupos nos outros períodos avaliados, contudo aos 10 dias as culturas 3D e 3D+VB apresentaram as maiores taxas de viabilidade celular, o que talvez possa ser explicado pelo rompimento da organização da matriz extracelular através da contração e remodelação do colágeno que resulta da ação de enzimas proteolíticas secretadas principalmente pelas próprias células, e que pode ter contribuído positivamente para a proliferação nesse período. Esta contração do colágeno mostra-se consistente com as observações de outros estudos (Velazquez et al., 2002; Neeley et al., 2010).

Análises morfológicas por microscopia de fluorescência mostram que as células cultivadas nas superfícies controle, 2D e 2D+VB apresentaram o mesmo padrão de espraiamento e imunomarcações para OPN e BSP, sugerindo que as partículas de VB e seus produtos de dissolução iônica não exercem influência nesses processos. A análise por microscopia confocal das culturas tridimensionais mostrou que as células estão aderidas nas superfícies das partículas alterando a sua morfologia e discretas imunomarcações intracelulares para OPN e BSP foram observadas 
apenas nas células em 3D. Apesar de essas marcações sugerirem a presença do fenótipo osteoblástico, a sua importância biológica é ainda desconhecida.

A atividade de ALP é um marcador importante para a linhagem osteoblástica e a diminuição subsequente está relacionada com mineralização da matriz e um fenótipo mais maduro (Aubin et al., 1995; Jaiswal et al., 1997). Foi observado que as culturas que continham VB (2D+VB e 3D+VB) apresentaram níveis mais elevados da atividade de ALP no período de 7 dias, sugerindo uma influência positiva das partículas sobre a atividade de ALP, assim como mostrado na literatura (Radin et al., 2005; Reilly et al., 2007). Por outro lado, as células cutivadas nos arcabouços tridimensionais (3D e 3D+VB) apresentaram níveis mais baixos de atividade de ALP aos 14 dias, o que difere de outro estudo no qual a atividade dessa enzima foi mais elevada em células cultivadas em colágeno 3D (Fernandes et al., 2009). No entanto, isto poderia ser explicado devido ao fato de que células osteogênicas em estágios precoces expressam uma maior atividade de ALP que as células na fase mais tardia onde essas culturas já estariam num processo de mineralização (Lian; Stein, 1992; Pockwinse et al., 1992). Além disso, existe a hipótese de que o colágeno tridimensional, estável e intacto cria um confinamento bioquímico, uma vez que as células estão incorporadas e isto possa interferir na atividade de ALP.

Uma sequência temporal na expressão gênica de proteínas da matriz tem sido estabelecida durante a formação óssea in vitro e in vivo (Owen et al., 1990; Stein; Lian, 1993). No presente estudo, os níveis de expressão de RNAm para ALP, COL e RUNX2 apresentaram upregulated nas células cultivadas em 3D e 3D+VB quando comparados com os níveis de expressão gênica das células na superfície controle. Essas observações estão consistentes com outros estudos, os quais utilizaram células osteoblásticas cultivadas em ambientes 3D comparados com 2D e relataram um aumento da expressão de RNAm para COL I, ALP (Kale et al., 2000; Trojani et al., 2005) e RUNX2 (Facer et al., 2005; Ko et al., 2007; Boehrs et al., 2008; Naito et al., 2011). Entretanto, outro estudo demonstrou uma downregulation da expressão de COL I e ALP em culturas 3D de osteoblastos humanos comparadas com culturas 2D (Boukhechba et al., 2009). Osteoblastos derivados da calvária ratos em cultura mostram um pico inicial de expressão do RNAm para OPN, seguido por um segundo pico principal de expressão quando as culturas começam a mineralizar (Owen et al., 1990). Os nossos resultados revelaram que as partículas de VB favoreceram os níveis de expressão de OPN, BSP e OC nas células cultivadas em 
2D+VB em comparação com 2D, corroborando com outros estudos que demostram que os produtos iônicos liberados pelo VB aumentam a expressão de marcadores osteogênicos importantes para a diferenciação dos osteoblastos (Xynos et al., 2001; Foppiano et al., 2007; Varanasi et al., 2009). Por outro lado, foi observada uma influência negativa da tridimensionalidade no padrão de expressão de $\mathrm{OC}$, semelhante a outro estudo utilizando osteoblastos humanos alveolares (Yefang et al., 2007) e OPN, diferente de outro estudo com osteoblastos cultivados em arcabouços 3D (Huang et al., 2004).

O desenvolvimento de condições in vitro que permitam a expressão do fenótipo osteoblástico e a produção de uma matriz extracelular que mineralize, oferece a possibilidade de analisar, em um ambiente bem definido, vários aspectos da formação óssea. As culturas celulares são os meios mais adequados para a investigação da diferenciação celular e dos primeiros eventos de elaboração e mineralização da matriz. O estabelecimento de células ósseas para estudos in vitro baseia-se essencialmente na liberação de células osteogênicas por meios enzimáticos ou físicos numa tentativa de obter uma população celular mais homogênea (Lian; Stein, 1992; Aubin et al., 1995; Nanci et al., 1996). No entanto, nem todas as linhagens celulares têm a capacidade de formar matriz mineralizada. A digestão enzimática da calvária de ratos recém-nascidos permite o isolamento de uma população de células heterogênea, composta de osteoprogenitores e préosteoblastos, osteoblastos diferenciados, osteócitos, e fibroblastos (Nanci et al., 1996; Aubin, 1998; De Oliveira et al., 2003). No presente estudo, os depósitos de cálcio na matriz foram demonstrados através da coloração com vermelho de Alizarina e quantificação pelo método colorimétrico (Gregory et al., 2004) em 10 e 14 dias. As culturas que continham VB (2D+VB e 3D+VB) apresentaram os melhores resultados de mineralização, mesmo que através da visualização por microscopia não tenha sido observada nenhuma relação de proximidade entre os nódulos e as partículas. Nossos achados concordam com outros estudos nos quais diferentes VB forneceram uma situação favorável para as células da medula (Bosetti; Cannas, 2005) e osteoblastos de ratos fetais (Vrouwenvelder et al., 1992; 1993; 1994; Loty et al., 2001; Roriz et al., 2010), promoveram a diferenciação e suportaram áreas significativamente maiores de matriz calcificada. Da mesma forma, Matsuda e Davies (Matsuda; Davies, 1987) mostraram proliferação celular e produção de matriz extracelular em vidros bioativos versus não ativos em culturas de células 
osteogênicas da calvária de ratos. Os resultados do presente estudo também revelaram que a tridimensionalidade interferiu a quantidade de cálcio formada, o que está de acordo com outros estudos nos quais a deposição de cálcio aumentou significativamente quando comparadas culturas 3D e 2D (Komori et al., 1997; Nakamura et al., 2009). Além disso, foi demonstrado que o revestimento bidimensional de colágeno (2D) pouco influenciou no conteúdo de cálcio, o que está de acordo com outro estudo (Becker et al., 2002). Isso pode ser explicado pela falta de renovação celular contínua, que é uma característica do sistema in vitro utilizado, levando a uma redução na população de osteoblastos ativos durante a fase de mineralização (De Assis et al., 2009).

Estudos anteriores in vitro, demonstrando que os VB suportam o crescimento e maturação de células osteoblásticas e promovem a expressão e manutenção do fenótipo osteoblástico, sugerem que existe tanto um efeito de superfície como uma solução mediada e controlada sobre a atividade celular. No entanto, a comparação direta com diferentes estudos é difícil, pois existem variações dos estudos em termos de composição e geometria do biomaterial, bem como condições de cultura: com ou sem meio de diferenciação osteogênica, e os períodos de avaliação. Além disso, os mecanismos de ação desses biomateriais não são completamente compreendidos e pensa-se ser o resultado da química no ambiente extracelular criado por sua dissolução. 


\subsection{Artigo em Inglês}

Bioactive glass particles in bi-dimensional and three-dimensional osteogenic cell cultures

L. B. Alves ${ }^{1}$, A. B. Novaes Jr ${ }^{1}$, M. F. M. Grisi ${ }^{1}$, S. L. S. Souza ${ }^{1}$, M. Taba Jr ${ }^{1}$, P. T. de Oliveira $^{2}$, V. M. Freitas ${ }^{3}$, D. B. Palioto ${ }^{1}$.

Corresponding author: Daniela Bazan Palioto

Department of Oral Surgery and Periodontology, University of São Paulo - School of Dentistry of Ribeirão Preto

Av. do Café - s/n,

Ribeirão Preto, SP, Brazil, Zip Code 14040-904

Fax number:+55 1636024788

e-mail: dpalioto@forp.usp.br

Support: FAPESP (grant number 2009/15.525-6)

There is no conflict of interest to declare

Short running title: Bioactive glass in osteogenic 3D culture

\footnotetext{
${ }^{1}$ Department of Oral Surgery and Periodontology, University of São Paulo - School of Dentistry of Ribeirão Preto

${ }^{2}$ Department of Morphology, Stomatology and Physiology, University of São Paulo - School of Dentistry of Ribeirão Preto

${ }^{3}$ Department of Cell and Developmental Biology, University of Sao Paulo
} 


\section{Abstract}

Background: The purpose of this study was to examine the influence of bioactive glass (BG) particles in bi (2D) and three-dimensional (3D) cultures on the phenotypic characterization of rat calvaria osteogenic cells in vitro.

Methods: Rat calvaria osteogenic cells were seeded on 2D and 3D collagen with BG particles for up to 14 days. The following parameters were assessed: cell viability, total protein content, alkaline phosphatase (ALP) activity, immunolocalization of osteopontin (OPN) and bone sialoprotein (BSP), and Alizarin red staining mineralization. Finally, total RNA was extracted and RT-PCR was performed for osteoblastic gene analysis.

Results: Experimental cultures did not produce an increased rate of cell proliferation/viability in comparison with the control surface. Total protein content and immunolabeling for OPN and BSP in osteogenic cells were increased by threedimensional conditions, but BG particles did not show any influence at 7 and 14 days. Although, ALP activity at 7 days was higher on cultures with BG particles, on $3 D$ and $3 D+B G$ had a great decrease at 14 days. Collagen three-dimensional scaffolds contributed to the expression of ALP and COL I mRNAs and the BG particles positively influenced the OC and OPN mRNAs expression and calcified nodule formation in vitro.

Conclusion: 3D cultures were able to support osteogenic cells viability, proliferation, differentiation and expression of osteoblastic phenotype and the BG particles contributed to differentiation and mineralized matrix formation.

Key words: osteogenic cells, bioactive glass, collagen type I 


\section{Introduction}

Bioactive glass $(B G)$ is a bone repairing material that bonds strongly to bone and promotes bone growth in vivo implantation (1). The enhanced bone growth induced by $B G$ was the result of a multistage mechanism that began as the glass contacted physiological fluids. The first stages involved the release of $\mathrm{Na}^{+}$and $\mathrm{Ca}^{2+}$ as they exchanged $\mathrm{H}^{+}$ions in the fluid, followed by the slow release of soluble silicon (1). These ions are believed to stimulate osteogenesis (2).

In osteogenesis and matrix formation, in vitro studies are frequently based on two-dimensional (2D) culture. However, it is well established that differences exist between cells grown in 2D culture and cells found in their native three-dimensional (3D) environment (3-5). To simulate the 3D environment, researchers have been looking for appropriate scaffolds or carriers for cell implantation. Collagen is the most useful biomaterial that has been used for tissue engineering purposes due its excellent biocompatibility and safety associated with its biological characteristics, such as biodegradability and weak antigenicity (6).

Osteogenic cell culture systems are routinely used to study the tightly regulated cellular and extracellular matrix events of bone formation in a controlled environment. A commonly used system to study bone formation in vitro is the primary culture of rat calvaria osteogenic cells (well-characterized as an abundant source of osteoblasts and committed osteoprogenitor cells). Cell isolation procedures, culture conditions, the temporal sequence of osteoblastic differentiation, and expression of matrix proteins have been well defined for this system (7). The expression pattern of matrix proteins in vitro has been correlated with acquisition and maturation of the osteoblast phenotype (8-10).

There is evidence that $3 D$ culture is able to support osteogenic differentiation and matrix production of primary human osteoblasts (11-13). Also the ionic products of BG enhance cementoblast proliferation (14), osteoblast attachment, proliferation, differentiation, and mineralization (15), and induce differentiation of bone marrow stromal cells into mature extracellular producing osteoblasts (16). It is reasonable to suggest that the 3D collagen and BG particles could have a similar effect on osteogenic cells derived from newborn rat calvaria. This study focused on evaluating the effect of BG particles on osteogenic cells behavior cultured on $2 \mathrm{D}$ and $3 \mathrm{D}$ collagen gel. Considering whether, the three-dimensionality, collagen and ionic product of BG particles could induce these cells to an osteoblastic phenotype. 


\section{Materials and methods}

The osteogenic cells derived from newborn rat calvaria were seeded on 3D scaffolds with $B G$ particles (3D+BG) and without particles (3D); 2D collagen surface with $B G$ particles $(2 D+B G)$ and without particles (2D); and on plastic coverslip Thermanox $^{\mathrm{TM}}$ (Nunc, NY, USA) (control).

\section{Cell isolation and primary culture of osteogenic cells}

Osteogenic cells were isolated by sequential trypsin/collagenase digestion of calvarial bone from newborn (2-4 days) Wistar rats, as previously described (17-20). Cells were seeded by over lay method on different groups at a density of $2 \times 10^{4}$ cells per well for periods of up to 14 days in $1 \mathrm{~mL}$ of osteogenic medium a-MEM supplemented with $10 \%$ FBS, $0.3 \mathrm{mg} / \mathrm{mL}$ fungizone, $50 \mu \mathrm{g} / \mathrm{mL}$ gentamycin, $5 \mu \mathrm{g} / \mathrm{mL}$ of ascorbic acid (Gibco, Invitrogen, MD, USA) and $7 \mathrm{mM} \beta$-glycerophosphate (Sigma, St. Louis, USA) and dexamethasone $10^{7}$ (Sigma, St. Louis, USA) and maintained in a humidified atmosphere with $5 \% \mathrm{CO} 2$ and $95 \%$ air at $37^{\circ} \mathrm{C}$. The culture medium was changed every $2-3$ days. All animal procedures were in accordance with guidelines of the Animal Research Ethics Committee from the School of Dentistry of Ribeirão Preto, University of São Paulo, Brazil (n. 09.1.1210.53.0).

\section{Preparation of scaffolds}

3D scaffolds were prepared by mixing the collagen solution $(3 \mathrm{mg} / \mathrm{mL}$, bovine Col I) (BD Science, MS, USA) with a mixture solution of $1 \mathrm{M}$ of $\mathrm{NaOH}, 186 \mathrm{mM} \mathrm{NaHCO}_{3}$ and $\alpha$-minimum essential medium ( $\alpha-M E M)$ (Gibco, Invitrogen, MD, USA). The final concentration of collagen was determined to be $2 \mathrm{mg} / \mathrm{mL}$. Then, $250 \mu \mathrm{L}$ of collagen solution were placed in each well containing a plastic coverslip (plate of 24 wells) (Corning Incorporated, NY, USA) and maintained in an incubator under a humidified atmosphere of $5 \% \mathrm{CO}_{2}$ in $95 \%$ air at $37^{\circ} \mathrm{C}$ for $15 \mathrm{~min}$, until the solution solidified into a collagen gel matrix.

2D surfaces were prepared by diluting the collagen on Phosphate Buffered Saline (PBS) (Gibco, Invitrogen, MD, USA) for the final concentration to be $50 \mu \mathrm{L} / \mathrm{mg}$. After that, $100 \mu \mathrm{L}$ of collagen dilution were placed in each well containing a plastic coverslip (plate of 24 wells) and maintained at room temperature (RT) for $1 \mathrm{~h}$. After this period, the remaining solutions were aspirated. 
The BG particles (Biogran ${ }^{\circledR}$, Biomet 3i, FL, USA) were seeded $30 \mu \mathrm{g} /$ well 3D+BG and $2 \mathrm{D}+\mathrm{BG}$, before the gel polymerization and drying of the collagen $2 \mathrm{D}$. For the control surfaces a coverslip were used, considering the need to remove the film for immunofluorescence analysis.

\section{Cell Viability/Proliferation}

Cell viability/proliferation was evaluated by 3-[4,5-dimethylthiazol-2-yl]-2,5diphenyltetrazolium bromide (MTT) (Sigma, St. Louis, USA) assay at 3, 7 and 10 days (17). Cells were incubated with $10 \%$ MTT $(5 \mathrm{mg} / \mathrm{mL})$ in culture medium at $37^{\circ} \mathrm{C}$ for $4 \mathrm{~h}$. The medium was then aspirated from the well, and $1 \mathrm{~mL}$ of acid isopropanol (0.04 $\mathrm{NHCl}$ in isopropanol) was added to each well.

The plates were then stirred on a plate shaker for $5 \mathrm{~min}$, and $200 \mu \mathrm{L}$ of this solution was transferred to a 96-well format using opaque-walled transparentbottomed plates (Fisher Scientific, PA, USA). Optical density was read at $570 \mathrm{~nm}$ on the plate reader ( $\mu$ Quant Biotek Instruments, VT, USA) and data were expressed as absorbance.

\section{Total Protein Content and Alkaline Phosphatase Activity}

Total protein content was determined at 7 and 14 days by a modification of the Lowry method (18). Proteins were extracted from each well with $0.1 \%$ sodium lauryl sulphate for $30 \mathrm{~min}$ and mixed 1:1 with Lowry solution (Sigma, St. Louis, USA) for 20 min at RT. The extract was diluted in Folin and Ciocalteau's phenol reagent ${ }^{* *}$ for 30 min at RT. Absorbance was measured at $680 \mathrm{~nm}$ using a spectrophotometer ( $\mu$ Quant Biotek Instruments, VT, USA). The total protein content was calculated from a standard curve and expressed as $\mu \mathrm{g} / \mathrm{mL}$.

Alkaline phosphatase (ALP) activity was assayed in the same lysates used for determining total protein content as the release of thymolphthalein from thymolphthalein monophosphate by using a commercial kit (Labtest Diagnostica, MG, Brazil). Briefly, $50 \mu \mathrm{L}$ of thymolphthalein monophosphate were mixed with 0.5 $\mathrm{mL}$ of $0.3 \mathrm{M}$ diethanolamine buffer, $\mathrm{pH} 10.1$, and left for 2 min at $37^{\circ} \mathrm{C}$.

The solution was then added to $50 \mu \mathrm{L}$ of the lysates obtained from each well for $10 \mathrm{~min}$ at $37^{\circ} \mathrm{C}$. For color development, $2 \mathrm{~mL}$ of $0.09 \mathrm{M} \mathrm{Na} 2 \mathrm{CO} 3$ and $0.25 \mathrm{M} \mathrm{NaOH}$ were added. After $30 \mathrm{~min}$, absorbance was measured using a spectrophotometer ( $\mu$ Quant Biotek Instruments, VT, USA) at $590 \mathrm{~nm}$ and ALP activity was calculated 
from a standard curve using thymolphthalein to give a range from 0.012 to $0.4 \mu \mathrm{mol}$ thymolphthalein $/ \mathrm{h} / \mathrm{mL}$. Data were expressed as ALP activity normalized for total protein content.

Indirect immunofluorescence for localization of Bone Sialoprotein (BSP) and osteopontin (OPN)

At days 7 and 14, cells were fixed for $10 \mathrm{~min}$ at RT using 4\% paraformaldehyde in $0.1 \mathrm{M}$ phosphate buffer (PB), $\mathrm{pH}$ 7.2. After washing in $\mathrm{PB}$, they were processed for immunofluorescence labeling. Briefly, cells were permeabilized with $0.5 \%$ Triton $X$ 100 in PB for 10 min followed by blocking with $5 \%$ skimmed milk in PB for 30 min. Primary monoclonal antibodies to BSP (anti-BSP, 1:200, WVID-9C5) (Developmental Studies Hybridoma Bank, lowa, USA) and OPN (anti-OPN, 1:800, MPIIIB10-1) (Developmental Studies Hybridoma Bank, lowa, USA) were used, followed by a mixture of Alexa Fluor 594 (red fluorescence)- conjugated goat anti-mouse secondary antibody (1:200) (Molecular Probes, Invitrogen, MD, USA), and Alexa Fluor 488 (green fluorescence) - conjugated phalloidin (1:200) (Molecular Probes, Invitrogen, MD, USA) for $50 \mathrm{~min}$ at RT in a humidified environment, for the detection of actin cytoskeleton and cell periphery. Replacement of the primary monoclonal antibody with PB was used as control. All antibody incubations were performed in a humidified environment for 60 min at RT. Between each incubation step, the samples were washed three times (5 min each) in PB. Before mounting for microscope observation, samples were briefly washed with $\mathrm{dH}_{2} \mathrm{O}$ and cell nuclei stained with DAPI (1:300) (Molecular Probes, Invitrogen, MD, USA) for 5 min. After, the coverslip containing $3 \mathrm{D}$ collagen gel, $2 \mathrm{D}$ collagen and the control were placed carefully face down on glass slides and mounted with Vectashield antifade (Vector Laboratories, CA, USA). The control and bi-dimensional samples were then examined under epifluorescence using a Leica DMLB light microscope (Leica, Bensheim, Germany), with N Plan (X10/0.25, X20/0.40) and HCX PL Fluotar (X40/0.75) objectives, outfitted with a Leica DC 300F digital camera, 1.3 Megapixel CCD. The acquired digital images were processed with Adobe Photoshop software (version 7.0) (Adobe Systems Inc., CA, USA). The three-dimensional samples were examined under confocal microscopy (Leica TCS-SP2 SE laser scanning system). 
Gene expression analysis using real-time PCR

At 7 days gene expression of Alkaline phosphatase (ALP), Osteopontin (OPN), Osteocalcin (OC), Collagen I (COL I) and Runx2 was measured, which characterize the osteoblast phenotype genes to test whether three-dimensional conditions and bioactive particles favor the development of phenotype cells to produce mineralized matrix. For the analyses of gene expression the plating density was $4 \times 10^{4}$ cells / well on the three-dimensional scaffolds. $\beta$-actin (ACTB) was evaluated as control for constitutive gene expression. The gene expression analysis was performed by realtime PCR as described below.

Total RNA was isolated using the TRIZOL $®$ reagent (Gibco, Invitrogen, MD, USA) according to the manufacturer's instructions. The concentration of RNA was determined by optical density at a wavelength of $260 \mathrm{~nm}$, using the GeneQuant (Amersham Biosciences, NJ, USA). The RNA purity was determined from A260/A280 (System for RT-PCR) (Invitrogen, CA, USA). Complementary DNA (cDNA) was synthesized using $1 \mathrm{\mu g}$ of RNA through a reverse transcription reaction (Highcapacity cDNA Reverse Transcription Kits) (Applied Biosystems, CA, EUA). Realtime PCR quantitative mRNA analyses were performed in CFX96 (Bio-Rad, CA, USA) using SybrGreen system (Applied Biosystems, CA, EUA). SybrGreen PCR MasterMix, specific primers and $2.5 \mathrm{ng}$ of cDNA were used in each reaction. The standard PCR conditions were $50^{\circ} \mathrm{C}(2 \mathrm{~min}), 95^{\circ} \mathrm{C}(10 \mathrm{~min})$ and 40 cycles of $15 \mathrm{~s}$ at $95^{\circ} \mathrm{C}$, and a final cycle of $20 \mathrm{~min}$ with increasing temperature of $60^{\circ} \mathrm{C}$ to $95^{\circ} \mathrm{C}$, followed by the standard denaturation curve. The primers used were in table 1.

Each assay was run in duplicate. For mRNA analysis, the relative level of gene expression was calculated in reference to both $\beta$-actin expression in the sample and its respective control using the cycle threshold (Ct) method (19).

\section{Mineralized bone-like nodule formation and calcium content}

At day 10 and 14, cultures were fixed with $4 \%$ formaldehyde in $\mathrm{PB}, \mathrm{pH} 7.2$, for 2 $\mathrm{h}$ at RT and washed in the same buffer. The samples were then dehydrated in a graded series of alcohol and stained with $2 \%$ Alizarin red S (Sigma, St. Louis, USA), $\mathrm{pH} 4.2$, for $8 \mathrm{~min}$ at RT. They were imaged by epifluorescence microscopy. The quantification of color was evaluated by colorimetric method (20). The absorbance was measured on a spectrophotometer ( $\mu$ Quant Biotek Instruments, VT, USA) at a 
wavelength of $405 \mathrm{~nm}$. The mineralized matrix formation was expressed as optical density.

\section{Statistical analysis}

Data presented in this work are the pool of three separate experiments in cell cultures established. All experiments were carried out in quintuplicate $(n=5)$ with the exception of real-time RT-PCR, which was done in triplicate $(n=3)$. Nonparametric data were submitted to Kruskal-Wallis test, for independent samples, followed by Dunn test for multiple comparisons. Parametric data were submitted to one-way analysis of variance (ANOVA) followed by a Tukey's test, which was used for multiple comparisons. SigmaStat program (version 3.5) (Statcon, Witzenhausen, Germany) was used and a value of $p<0.05$ was considered statistically significant.

\section{Results}

\section{Cell Viability/Proliferation}

In general, all groups presented a time dependent increased in viability/proliferation rates.MTT assay showed that cell viability/proliferation was negatively affected by the 3D culture and BG particles at 7 days. Cultures on 3D+BG produced a decreased rate of cell proliferation/viability in comparison with the control and 2D+BG surfaces $(p<0.05)$. However, at same time the BG particles enhanced the cell viability/proliferation on 2D+BG cultures. At 3 and 10 days the levels of cell viability/proliferation were very similar; there was no significant difference between the groups (Fig. 1).

\section{Total Protein Content and Alkaline Phosphatase Activity}

At 7 and 14 days the $3 D$ and 3D+BG groups showed increased total protein content in osteogenic cells. A significant difference of total protein content was observed when 3D+BG cultures were compared with control $(p<0.05)$ and 2D+BG $(p<0.05)$ cultures (Fig. 1).

At 7 days the highest levels of ALP activity were observed in cells on BG cultures, which on $2 D+B G$ and $3 D+B G$ was significantly higher than on $2 D$ and $3 D$ $(p<0.05)$. Also, a statistic difference was observed when $3 D+B G$ cultures was compared with the control $(p<0.05)$. At 14 days the lowest levels of ALP activity were 
observed on $3 D$ and $3 D+B G$, and it was significantly different to $2 D(p<0.05)$ and $2 D+B G(p<0.05)$. Although there is no significant difference, $2 D$ and $2 D+B G$ cultures showed higher levels of ALP activity than cells cultured on the control surface and 2D+BG higher than 2D (Fig. 1).

Indirect immunofluorescence for localization of Bone Sialoprotein (BSP) and osteopontin (OPN)

On bi-dimensional and control surfaces the cells were spindle or polygonal shape, with an organized cytoskeleton, and actin stress fibers defined. A denser cell layer can be observed, indicating that cell proliferation occurred, and positive immunolocalization for OPN and BSP was observed by epifluorescence. The immunolabeling for OPN was seen mainly through perinuclear deposits, and for BSP as points in the cytoplasm and also in some perinuclear areas were visualized. There was also no relationship between this staining and BG particles (Fig. 2). On threedimensional cultures the cells showed a fusiform and elongated shape, also with an organized cytoskeleton and actin stress fibers defined. Positive immunolabeling for OPN and BSP has been observed mostly around the cell nucleus on 3D, but it could not be seen in cells on 3D+BG. A little positive immunostaining for these proteins was seen on the BG particles (Fig. 3).

\section{Gene expression analysis using real-time PCR}

The osteoblastic phenotype was confirmed at the transcriptional level by mRNA expression of the genes encoding COL I, ALP, OPN, BSP, Runx2 and OC. A significant difference between the groups for all evaluated genes, except to Runx2 and BSP was observed.

The levels expression of ALP, COL I and Runx2 were upregulated in cells cultured on $3 \mathrm{D}$ and $3 \mathrm{D}+\mathrm{BG}$ when compared with those on control surface, and the BG particles showed a positive influence in the levels of OPN, BSP and OC mRNA in the cells cultured on 2D+BG compared with 2D (Fig. 4).

The level expression COL I was significantly higher on cells cultured on 3D+BG than those on 2D+BG, in which the levels of OPN and OC mRNA were significantly higher than $2 \mathrm{D}$ and $3 \mathrm{D}+\mathrm{BG}$. The cells cultured on 2D, 3D and 3D+BG also showed the level expression of OPN and OC downregulated in comparision with those on the control surface (Fig. 4). 
Mineralized bone-like nodule formation and calcium content

At 10 and 14 days all groups exhibited areas of stained with Alizarin red. These areas presented more extensive on cultures containing BG particles, but by microscopy it was not seen necessarily in vincinity of the particles. (Fig.1). The quantitative analysis showed better results of calcified matrix formation on $B G$ cultures at 10 and 14 days. At 10 days the amount of calcium in 3D+BG was significantly higher than on the control surface, and it was also on 2D+BG greater than in 3D, 2D and control. At 14 days calcium content was significantly higher on $B G$ cultures (2D+BG and $3 D+B G$ ) than the control and 2D surfaces (Fig. 1).

\section{Discussion}

The present study evaluated the influence of BG particles on osteogenic cells derived from newborn rat calvaria on $3 \mathrm{D}$ and $2 \mathrm{D}$ cultures. Our results showed that the three-dimensionality and BG particles supported the cell viability and differentiation, ALP activity, mineralized nodules formation and the osteoblastic phenotype expression.

All groups presented an increase of viability/proliferation rate at the evaluated periods. However, the three-dimensionality interfered in the viability/proliferation rate at 7 days, which is in agreement with others studies which showed that cells on $2 \mathrm{D}$ substrates presented higher proliferation rates than cells seeded inside 3D collagen $(24,25)$. It can be explained due to the organization and maturation of the extracellular matrix surrounding osteoblasts to the shutdown of proliferation $(26,27)$. $B G$ particles enhanced the cell viability/proliferation rate on 2D+BG cultures, similar to other in vivo and in vitro studies that demonstrated that the BG particles are consistently effective to enhance osteoblast proliferation $(23,28,29)$. Significant differences were not observed between the groups at the others evaluated periods. However, at 10 days, cultures on $3 D$ and 3D+BG produced an increased rate of cell proliferation/viability. This may be explained by the disruption of the organization of the extracellular matrix surrounding osteoblasts through the collagen contraction and remodelling, as a result of the action of proteolytic enzymes secreted primarily by cells, and which may have contributed positively to the cell proliferation at this time. This contraction of the collagen complex at day 14 was consistent with the observations of other studies $(30,31)$. 
The ALP activity increasing is a marker of the commitment towards osteoblastic lineage, while the subsequent decrease correlates with advanced matrix mineralization and a more mature phenotype $(32,33)$. The higher levels of ALP activity were observed for cells on BG cultures at 7 days, suggesting a positive influence of BG particles on ALP activity of osteogenic cells, accordingly with other studies $(16,34)$. On the other hand, at 14 days the lowest levels of ALP activity were observed on $3 D$ and $3 D+B G$, which differs from the other study showing the highest ALP activity on 3D collagen (24). However it could be explained due to osteoblast progenitor cells in earlier stages of development, during the matrix maturation stage, express greater ALP activity than more differentiated cells in the later mineralization stage $(35,36)$. Furthermore, there is a hypothesis that three-dimensional collagen still stable and intact, and cells embedded in the collagen gel are closely surrounded by the collagen network that creates a biochemical confinement (37), which could be interfere in the ALP activity. Although there is no significant difference, 2D and 2D+BG showed higher levels of ALP activity than the control surface.

A temporal sequence in gene expression has been clearly established during bone formation in vitro and in vivo $(7,8)$. In the present study, the levels expression of ALP, COL I and Runx2 were upregulated in cells cultured on 3D and 3D+BG when compared with those on the control surface. Our observations are consistent with other studies, using primary human osteoblasts in static 3D culture conditions, which demonstrated an upregulation of $\operatorname{COL} I, \operatorname{ALP}(38,39)$ and $\operatorname{Runx} 2(3,4,25,40)$ in osteoblastic cells cultured in 3D environments, as compared to those cultured 2D. On the contrary, there are also data reporting a downregulation of COL I and ALP in human osteoblast 3D cultures compared to monolayer after 7 and 14 days without osteogenic induction (13). Additionally, it has been reported that rat calvaria cells grown on films of collagen type I differentiate earlier and consequently express lower levels of COL mRNA compared with cells grown on polystyrene (9), and similar results were obtained in the present study. In rat calvaria-derived osteoblast cultures, the cells show an initial peak of OPN mRNA expression at early culture times, followed by a second major peak of expression when the cultures begin to mineralize (8). Our results demonstrated a positive influence of $B G$ particles in the expression levels of OPN, BSP and OC in the cells cultured on 2D+BG compared with 2D, in accordance with other studies showing that the ionic products released by the BG enhance the expression of osteogenic markers important for osteoblast differentiation 
(41-43). Also a negative influence of the three-dimensionality on expression pattern $\mathrm{OC}$, similar to another study using primary human alveolar osteoblasts was observed (12). This also differs from reports about osteoblasts cultured on 3D scaffolds which showed an increased expression of OPN (44). By confocal microscopy we identified discrete patterns of intracellular OPN and BSP staining, with some variations apparent in individual cells. These staining patterns suggested the presence of osteoblastic phenotype, but their biological significance is presently unknown.

The development of in vitro conditions which are permissive for the expression of the osteoblast phenotype and the production of an extracellular matrix which mineralizes, offers the possibility to examine, in a well-defined environment, various aspects of bone formation. The cell cultures are best suited for investigating cell differentiation and the earliest events of matrix elaboration and mineralization. The establishment of normal bone cell populations for in vitro studies relies essentially on the release of osteogenic cells by enzymatic or physical means or on the differentiation of precursor cells derived from bone marrow transformed osteogenic cells which have also been used in an attempt to obtain more homogenous cell populations $(33,35,45)$. However, not all these cell lines have the ability to form mineralized, bone-like matrix. Trypsin/collagenase digestion of newborn rat calvarial bone allows the isolation of a mixed, heterogeneous cell population composed of osteoprogenitors, preosteoblasts, differentiated osteoblasts, osteocytes, and fibroblasts (45-48). Under the osteogenic conditions used in this study, calvariaderived primary cultures generate woven bone-like nodules, which have been demonstrated to derive from the clonal expansion of osteoprogenitors and their entry into the osteoblast differentiation sequence $(45,47-49)$. The role of isolated active osteoblasts in the process of matrix mineralization in vitro is still unclear $(46,50)$. In the present study, calcium deposits in the matrix were demonstrated by alizarin red staining and quantification by colorimetric method (20) at 10 and 14 days. Calcium deposits were significantly greater on cultures with $B G(2 D+B G$ and $3 D+B G)$, even by the microscopic examination no close relationshion between the mineralized nodules and the particles was observed. Our findings agree with other studies in which different bioactive glasses provided a favorable situation for marrow cells (22) and fetal rat osteoblasts $(23,51-54)$ to promote differentiation and to support significantly larger areas of calcified matrix. In the same way, Matsuda and Davies (55) showed a better cellular colonization and extracellular matrix production on 
bioactive glasses versus nonbioactive glasses in calvaria organ cultures. Our results also revealed that the three-dimensionality interfered in the amount of calcium, differing from other studies which considered that calcium deposition was significantly increased in 3D compared with 2D $(56,57)$. Indeed, it has been demonstrated that the calcium content collagen was slightly affected by coating collagen on 2D, which is in accordance with the other study (58). That could be explained by the absence of continuous cell renewal, which is a characteristic of the in vitro system used, leading to a reduction in the population of active osteoblasts during the mineralization phase (59).

\section{Conclusion}

The results showed that the three-dimensionality and BG particles supported the cellular viability and differentiation, ALP activity, mineralized nodules formation and favored the genic expression characteristic of osteoblastic phenotype.

\section{References}

(1) Hench LL, Paschall HA. Direct chemical bond of bioactive glass-ceramic materials to bone and muscle. Journal of biomedical materials research 1973; 7: 25-42.

(2) Xynos ID, Hukkanen MV, Batten JJ, Buttery LD, Hench LL, Polak JM. Bioglass 45S5 stimulates osteoblast turnover and enhances bone formation In vitro: implications and applications for bone tissue engineering. Calcified tissue international 2000; 67: 321329.

(3) Facer SR, Zaharias RS, Andracki ME, Lafoon J, Hunter SK, Schneider GB. Rotary culture enhances pre-osteoblast aggregation and mineralization. Journal of dental research 2005; 84: 542-547.

(4) Boehrs J, Zaharias RS, Laffoon J, Ko YJ, Schneider GB. Three-dimensional culture environments enhance osteoblast differentiation. Journal of prosthodontics : official journal of the American College of Prosthodontists 2008; 17: 517-521.

(5) Rucci N, Migliaccio S, Zani BM, Taranta A, Teti A. Characterization of the osteoblastlike cell phenotype under microgravity conditions in the NASA-approved Rotating Wall Vessel bioreactor (RWV). Journal of cellular biochemistry 2002; 85: 167-179.

(6) Lee $\mathrm{CH}$, Singla A, Lee Y. Biomedical applications of collagen. International journal of pharmaceutics 2001; 221: 1-22.

(7) Stein GS, Lian JB. Molecular mechanisms mediating proliferation/differentiation interrelationships during progressive development of the osteoblast phenotype. Endocrine reviews 1993; 14: 424-442.

(8) Owen TA, Aronow M, Shalhoub V, et al. Progressive development of the rat osteoblast phenotype in vitro: reciprocal relationships in expression of genes associated with osteoblast proliferation and differentiation during formation of the bone extracellular matrix. Journal of cellular physiology 1990; 143: 420-430. 
(9) Lynch MP, Stein JL, Stein GS, Lian JB. The influence of type I collagen on the development and maintenance of the osteoblast phenotype in primary and passaged rat calvarial osteoblasts: modification of expression of genes supporting cell growth, adhesion, and extracellular matrix mineralization. Experimental cell research 1995; 216: 35-45.

(10) Moursi AM, Damsky $\mathrm{CH}$, Lull J, et al. Fibronectin regulates calvarial osteoblast differentiation. Journal of cell science 1996; 109 ( Pt 6): 1369-1380.

(11) Ferrera D, Poggi S, Biassoni C, et al. Three-dimensional cultures of normal human osteoblasts: proliferation and differentiation potential in vitro and upon ectopic implantation in nude mice. Bone 2002; 30: 718-725.

(12) Yefang Z, Hutmacher DW, Varawan SL, Meng LT. Comparison of human alveolar osteoblasts cultured on polymer-ceramic composite scaffolds and tissue culture plates. International journal of oral and maxillofacial surgery 2007; 36: 137-145.

(13) Boukhechba F, Balaguer T, Michiels JF, et al. Human primary osteocyte differentiation in a 3D culture system. Journal of bone and mineral research : the official journal of the American Society for Bone and Mineral Research 2009; 24: 1927-1935.

(14) Carvalho SM, Oliveira AA, Jardim CA, et al. Characterization and induction of cementoblast cell proliferation by bioactive glass nanoparticles. J Tissue Eng Regen Med 2011.

(15) Kaufmann EA, Ducheyne P, Shapiro IM. Effect of varying physical properties of porous, surface modified bioactive glass $45 \mathrm{~S} 5$ on osteoblast proliferation and maturation. Journal of biomedical materials research 2000; 52: 783-796.

(16) Radin S, Reilly G, Bhargave G, Leboy PS, Ducheyne P. Osteogenic effects of bioactive glass on bone marrow stromal cells. Journal of biomedical materials research Part $A$ 2005; 73: 21-29.

(17) Mosmann T. Rapid colorimetric assay for cellular growth and survival: application to proliferation and cytotoxicity assays. J Immunol Methods 1983; 65: 55-63.

(18) Lowry OH, Rosebrough NJ, Farr AL, Randall RJ. Protein measurement with the Folin phenol reagent. J Biol Chem 1951; 193: 265-275.

(19) Livak KJ, Schmittgen TD. Analysis of relative gene expression data using real-time quantitative PCR and the 2(-Delta Delta C(T)) Method. Methods 2001; 25: 402-408.

(20) Gregory CA, Gunn WG, Peister A, Prockop DJ. An Alizarin red-based assay of mineralization by adherent cells in culture: comparison with cetylpyridinium chloride extraction. Analytical biochemistry 2004; 329: 77-84.

(21) Schindler M, Nur EKA, Ahmed I, et al. Living in three dimensions: 3D nanostructured environments for cell culture and regenerative medicine. Cell biochemistry and biophysics 2006; 45: 215-227.

(22) Bosetti M, Cannas M. The effect of bioactive glasses on bone marrow stromal cells differentiation. Biomaterials 2005; 26: 3873-3879.

(23) Loty C, Sautier JM, Tan MT, et al. Bioactive glass stimulates in vitro osteoblast differentiation and creates a favorable template for bone tissue formation. Journal of bone and mineral research : the official journal of the American Society for Bone and Mineral Research 2001; 16: 231-239.

(24) Fernandes LF, Costa MA, Fernandes MH, Tomas H. Osteoblastic behavior of human bone marrow cells cultured over adsorbed collagen layer, over surface of collagen gels, and inside collagen gels. Connective tissue research 2009; 50: 336-346.

(25) Naito $H$, Dohi $Y$, Zimmermann $W H$, et al. The effect of mesenchymal stem cell osteoblastic differentiation on the mechanical properties of engineered bone-like tissue. Tissue engineering Part A 2011; 17: 2321-2329.

(26) Riccio M, Resca E, Maraldi T, et al. Human dental pulp stem cells produce mineralized matrix in 2D and 3D cultures. European journal of histochemistry : EJH 2010; 54: e46. 
(27) Ozawa R, Yamada Y, Nagasaka T, Ueda M. A comparison of osteogenesis-related gene expression of mesenchymal stem cells during the osteoblastic differentiation induced by type-I collagen and/or fibronectin Int J Oral Med Sci 2003; 1: 139-146.

(28) Sun JY, Yang YS, Zhong J, Greenspan DC. The effect of the ionic products of Bioglass dissolution on human osteoblasts growth cycle in vitro. Journal of tissue engineering and regenerative medicine 2007; 1: 281-286.

(29) Au AY, Au RY, Demko JL, McLaughlin RM, Eves BE, Frondoza CG. Consil bioactive glass particles enhance osteoblast proliferation and selectively modulate cell signaling pathways in vitro. Journal of biomedical materials research Part A 2010; 94: 380-388.

(30) Velazquez OC, Snyder R, Liu ZJ, Fairman RM, Herlyn M. Fibroblast-dependent differentiation of human microvascular endothelial cells into capillary-like 3dimensional networks. FASEB journal : official publication of the Federation of American Societies for Experimental Biology 2002; 16: 1316-1318.

(31) Neeley WW, Carnes DL, Cochran DL. Osteogenesis in an in vitro coculture of human periodontal ligament fibroblasts and human microvascular endothelial cells. Journal of periodontology 2010; 81: 139-149.

(32) Jaiswal N, Haynesworth SE, Caplan AI, Bruder SP. Osteogenic differentiation of purified, culture-expanded human mesenchymal stem cells in vitro. Journal of cellular biochemistry 1997; 64: 295-312.

(33) Aubin JE, Liu F, Malaval L, Gupta AK. Osteoblast and chondroblast differentiation. Bone 1995; 17: 77S-83S.

(34) Reilly GC, Radin S, Chen AT, Ducheyne P. Differential alkaline phosphatase responses of rat and human bone marrow derived mesenchymal stem cells to 45S5 bioactive glass. Biomaterials 2007; 28: 4091-4097.

(35) Lian JB, Stein GS. Concepts of osteoblast growth and differentiation: basis for modulation of bone cell development and tissue formation. Critical reviews in oral biology and medicine : an official publication of the American Association of Oral Biologists 1992; 3: 269-305.

(36) Pockwinse SM, Wilming LG, Conlon DM, Stein GS, Lian JB. Expression of cell growth and bone specific genes at single cell resolution during development of bone tissuelike organization in primary osteoblast cultures. Journal of cellular biochemistry 1992; 49: 310-323.

(37) Berthod F, Hayek D, Damour O, Collombel C. Collagen synthesis by fibroblasts cultured within a collagen sponge. Biomaterials 1993; 14: 749-754.

(38) Kale S, Biermann S, Edwards C, Tarnowski C, Morris M, Long MW. Threedimensional cellular development is essential for ex vivo formation of human bone. Nature biotechnology 2000; 18: 954-958.

(39) Trojani C, Weiss P, Michiels JF, et al. Three-dimensional culture and differentiation of human osteogenic cells in an injectable hydroxypropylmethylcellulose hydrogel. Biomaterials 2005; 26: 5509-5517.

(40) Ko YJ, Zaharias RS, Seabold DA, Lafoon J, Schneider GB. Osteoblast differentiation is enhanced in rotary cell culture simulated microgravity environments. Journal of prosthodontics : official journal of the American College of Prosthodontists 2007; 16: 431-438.

(41) Varanasi VG, Saiz E, Loomer PM, et al. Enhanced osteocalcin expression by osteoblast-like cells (MC3T3-E1) exposed to bioactive coating glass (SiO2-CaOP2O5-MgO-K2O-Na2O system) ions. Acta biomaterialia 2009; 5: 3536-3547.

(42) Foppiano S, Marshall SJ, Marshall GW, Saiz E, Tomsia AP. Bioactive glass coatings affect the behavior of osteoblast-like cells. Acta biomaterialia 2007; 3: 765-771.

(43) Xynos ID, Edgar AJ, Buttery LD, Hench LL, Polak JM. Gene-expression profiling of human osteoblasts following treatment with the ionic products of Bioglass $45 \mathrm{~S} 5$ dissolution. Journal of biomedical materials research 2001; 55: 151-157. 
(44) Huang JC, Sakata T, Pfleger LL, et al. PTH differentially regulates expression of RANKL and OPG. Journal of bone and mineral research : the official journal of the American Society for Bone and Mineral Research 2004; 19: 235-244.

(45) Nanci A, Zalzal S, Gotoh Y, McKee MD. Ultrastructural characterization and immunolocalization of osteopontin in rat calvarial osteoblast primary cultures. Microscopy research and technique 1996; 33: 214-231.

(46) de Oliveira PT, Zalzal SF, Irie K, Nanci A. Early expression of bone matrix proteins in osteogenic cell cultures. The journal of histochemistry and cytochemistry : official journal of the Histochemistry Society 2003; 51: 633-641.

(47) Bellows CG, Aubin JE, Heersche JN, Antosz ME. Mineralized bone nodules formed in vitro from enzymatically released rat calvaria cell populations. Calcified tissue international 1986; 38: 143-154.

(48) Aubin JE. Advances in the osteoblast lineage. Biochemistry and cell biology = Biochimie et biologie cellulaire 1998; 76: 899-910.

(49) Bellows CG, Heersche JN, Aubin JE. Effects of dexamethasone on expression and maintenance of cartilage in serum-containing cultures of calvaria cells. Cell and tissue research 1989; 256: 145-151.

(50) Malaval L, Liu F, Roche P, Aubin JE. Kinetics of osteoprogenitor proliferation and osteoblast differentiation in vitro. Journal of cellular biochemistry 1999; 74: 616-627.

(51) Vrouwenvelder WC, Groot CG, de Groot K. Behaviour of fetal rat osteoblasts cultured in vitro on bioactive glass and nonreactive glasses. Biomaterials 1992; 13: 382-392.

(52) Vrouwenvelder WC, Groot CG, de Groot K. Histological and biochemical evaluation of osteoblasts cultured on bioactive glass, hydroxylapatite, titanium alloy, and stainless steel. Journal of biomedical materials research 1993; 27: 465-475.

(53) Vrouwenvelder WC, Groot CG, de Groot K. Better histology and biochemistry for osteoblasts cultured on titanium-doped bioactive glass: bioglass $45 \mathrm{~S} 5$ compared with iron-, titanium-, fluorine- and boron-containing bioactive glasses. Biomaterials 1994; 15: 97-106.

(54) Roriz VM, Rosa AL, Peitl O, Zanotto ED, Panzeri H, de Oliveira PT. Efficacy of a bioactive glass-ceramic (Biosilicate) in the maintenance of alveolar ridges and in osseointegration of titanium implants. Clinical oral implants research 2010; 21: 148155.

(55) Matsuda T, Davies JE. The in vitro responses of osteoblasts to bioactive glass. Biomaterials 1987; 8: 275-284.

(56) Nakamura A, Dohi Y, Akahane M, et al. Osteocalcin secretion as an early marker of in vitro osteogenic differentiation of rat mesenchymal stem cells. Tissue engineering Part C, Methods 2009; 15: 169-180.

(57) Komori T. Regulation of skeletal development by the Runx family of transcription factors. Journal of cellular biochemistry 2005; 95: 445-453.

(58) Becker D, Geissler U, Hempel U, et al. Proliferation and differentiation of rat calvarial osteoblasts on type I collagen-coated titanium alloy. Journal of biomedical materials research 2002; 59: 516-527.

(59) de Assis AF, Beloti MM, Crippa GE, de Oliveira PT, Morra M, Rosa AL. Development of the osteoblastic phenotype in human alveolar bone-derived cells grown on a collagen type I-coated titanium surface. Clinical oral implants research 2009; 20: 240 246. 


\section{Tables}

Table 1. Primer Sequences for Real-Time Polymerase Chain Reaction

\begin{tabular}{|c|c|c|}
\hline Genes & & Primer sequences \\
\hline \multirow{2}{*}{$\beta$-actin } & Forward & 5'-TGGGTATGGAATCCTGCTGC-3' \\
\hline & Reverse & 5'-CAGCTCAGTAACAGTCCG-3' \\
\hline \multirow{2}{*}{ Runx2 } & Forward & 5'-GAACTGATAGGACGCTGACGA-3' \\
\hline & Reverse & 5'-GCTTCTCCAACCCACGAATG-3' \\
\hline \multirow{2}{*}{ COL I } & Forward & 5'-TCCTGCCGATGTCGCTATC-3' \\
\hline & Reverse & 5'-CAAGTTCCGGTGTGACTCGTG-3' \\
\hline \multirow{2}{*}{ ALP } & Forward & 5'-CGAGCAGGAACAGAAGTTTGC-3' \\
\hline & Reverse & 5'-TGGCCAAAAGGCAGTGAATAG-3' \\
\hline \multirow{2}{*}{ OPN } & Forward & 5'-GCCTGTTCGGCCTTGCCTCCTGTCT-3' \\
\hline & Reverse & 5'-TCAGTCCGTAAGCCAAGCTATCACC-3' \\
\hline \multirow{2}{*}{ OC } & Forward & 5'-GCAGACACCATGAGGACCCT-3' \\
\hline & Reverse & 5'-CCAGAGTCTATTCACCACCTTACTG-3' \\
\hline \multirow{2}{*}{ BSP } & Forward & 5'-CTACTTTTATCCTCCTCCTCTGAAACGGTT-3 \\
\hline & Reverse & 5'-GCTAGCGGTTACCCCTGAGA-3' \\
\hline
\end{tabular}

\section{Figure legends}

Fig. 1 - A) Cell viability (means $\pm S D$ ) at 3, 7 and 10 days; B)Total protein content (means \pm SD) at 7 and 14 days $C$ ) Calcium content (means \pm SD) at 10 and 14 days; D) ALP Activity (means $\pm S D$ ) at 7 and 14 days. ${ }^{*} p<0.05$ (Kruskal-Wallis - Pos-test Dunn's) and ${ }^{* *} p<0.05$ (ANOVA - Pos-test Tukeys's)

Fig. 2 - Osteogenic cells grown on different bidimensional surfaces (control, 2D and $2 D+B G$ ) at 7 days. Epifluorescence of actin cytoskeleton labeling (phalloidin labeling, green fluorescence), DNA stain (DAPI, blue fluorescence), OPN (A-C C) and BSP (D-F) red fluorescence. Bar A-C: $50 \mu \mathrm{m}$ and Bar D-F: 100 $\mu \mathrm{m}$

Fig. 4 - Osteogenic cells grown on different three-dimensional surfaces (3D and $3 D+B G$ ) at 7 days. Fluorescence of actin cytoskeleton labeling (phalloidin labeling, green fluorescence), DNA stain (DAPI, blue fluorescence), OPN (A-B) and BSP (CD) red fluorescence observed in confocal microscopy. 
Fig. 4 - Gene expression of ALP, COL I, Runx2, BSP, OC and OPN in osteogenic cells cultured in different groups at 7 days using real-time PCR. Data were calculated as the relative expression of the target mRNA normalized to $\beta$-actin and to control (calibrator) and are reported as mean $\pm S D$. ${ }^{*} p<0.05$ (Kruskal-Wallis - Pos-test Dunn's).

Fig. 5 - Alizarin red staining showed limited amounts of mineralized nodule formation in osteogenic cultures. Control ( $a$ and A), 2D (b and B), 2D+BG (c and C), 3D ( $d$ and D) and 3D+BG (e and E). Bar: $200 \mu \mathrm{m}$. 
7. Conclusões da Tese 
Dentro das limitações da metodologia empregada no presente estudo e com base nos resultados obtidos, pode-se concluir que, em ambos os tipos celulares, as culturas colágenas tridimensionais e as partículas de vidro bioativo suportaram a viabilidade de hPDLF e favoreceram a diferenciação celular. A presença das partículas de vidro bioativo contribuíram de forma efetiva para a formação de nódulos mineralizados e expressão de alguns genes característicos dos fenótipos osteoblástico, tanto nas culturas bi quanto nas tridimensionais. 


\section{Referências Bibliográficas ${ }^{\dagger \dagger}$}

${ }^{\dagger \dagger}$ De acordo com o Estilo Vancouver:

US National Library of Medicine. Bibliographic Services Division. International Committee of Medical Journal Editors. Uniform Requirements for Manuscripts Submitted to Biomedical Journals: sample references. Estados Unidos, 1978 [cited 2006 Oct 25]. 
Abbott A. Cell culture: biology's new dimension. Nature 2003:424, 870-2.

Agarwal A; Mallapragada SK. Synthetic sustained gene delivery systems. Current topics in medicinal chemistry 2008:8, 311-0.

Altmann B; Steinberg T; Giselbrecht S; Gottwald E; Tomakidi P; Bachle-Haas M; Kohal RJ. Promotion of osteoblast differentiation in 3D biomaterial micro-chip arrays comprising fibronectin-coated poly(methyl methacrylate) polycarbonate. Biomaterials 2011:32, 8947-56.

Amatangelo MD; Bassi DE; Klein-Szanto AJ; Cukierman E. Stroma-derived threedimensional matrices are necessary and sufficient to promote desmoplastic differentiation of normal fibroblasts. The American journal of pathology 2005:167, 475-88.

Anselme K; Noel B; Flautre B; Blary MC; Delecourt C; Descamps M; Hardouin P. Association of porous hydroxyapatite and bone marrow cells for bone regeneration. Bone 1999:25, 51S-54S.

Arceo N; Sauk JJ; Moehring J; Foster RA; Somerman MJ. Human periodontal cells initiate mineral-like nodules in vitro. Journal of periodontology 1991:62, 499-503.

Asahina I; Sampath TK; Nishimura I; Hauschka PV. Human osteogenic protein-1 induces both chondroblastic and osteoblastic differentiation of osteoprogenitor cells derived from newborn rat calvaria. The Journal of cell biology 1993:123, 921-33.

Au AY; Au RY; Demko JL; Mclaughlin RM; Eves BE; Frondoza CG. Consil bioactive glass particles enhance osteoblast proliferation and selectively modulate cell signaling pathways in vitro. Journal of biomedical materials research. Part A 2010:94, 380-8.

Aubin JE. Advances in the osteoblast lineage. Biochemistry and cell biology = Biochimie et biologie cellulaire 1998:76, 899-910.

Aubin JE; Liu F; Malaval L; Gupta AK. Osteoblast and chondroblast differentiation. Bone 1995:17, 77S-83S.

Balooch M; Habelitz S; Kinney JH; Marshall SJ; Marshall GW. Mechanical properties of mineralized collagen fibrils as influenced by demineralization. Journal of structural biology 2008:162, 404-10. 
Barron MJ; Tsai CJ; Donahue SW. Mechanical stimulation mediates gene expression in MC3T3 osteoblastic cells differently in 2D and 3D environments. Journal of biomechanical engineering 2010:132, 041005.

Bartold PM; Mcculloch CA; Narayanan AS; Pitaru S. Tissue engineering: a new paradigm for periodontal regeneration based on molecular and cell biology. Periodontology 2000 2000:24, 253-69.

Bartold PM; Xiao Y; Lyngstaadas SP; Paine ML; Snead ML. Principles and applications of cell delivery systems for periodontal regeneration. Periodontology 2000 2006:41, 123-35.

Bartold PM; Xiao Y; Lyngstadaas SP; Paine ML; Snead ML. Princípios e aplicações dos sistemas de liberação celular para a regeneração periodontal. Periodontologia 2000 2008:15, 123-35.

Basdra EK; Komposch G. Osteoblast-like properties of human periodontal ligament cells: an in vitro analysis. European journal of orthodontics 1997:19, 615-21.

Becker D; Geissler U; Hempel U; Bierbaum S; Scharnweber D; Worch H; Wenzel $\mathrm{KW}$. Proliferation and differentiation of rat calvarial osteoblasts on type I collagencoated titanium alloy. Journal of biomedical materials research 2002:59, 516-27.

Beertsen W; Everts V; Van Den Hooff A. Fine structure of fibroblasts in the periodontal ligament of the rat incisor and their possible role in tooth eruption. Archives of oral biology 1974:19, 1087-98.

Beertsen W; Van Den Bos T. Calcification of dentinal collagen by cultured rabbit periosteum: the role of alkaline phosphatase. Matrix 1989:9, 159-71.

Beertsen W; Van Den Bos T. Alkaline phosphatase induces the deposition of calcified layers in relation to dentin: an in vitro study to mimic the formation of afibrillar acellular cementum. Journal of dental research 1991:70, 176-81.

Bell E; Ivarsson B; Merrill C. Production of a tissue-like structure by contraction of collagen lattices by human fibroblasts of different proliferative potential in vitro. Proceedings of the National Academy of Sciences of the United States of America 1979:76, 1274-8.

Bellows CG; Aubin JE. Determination of numbers of osteoprogenitors present in isolated fetal rat calvaria cells in vitro. Developmental biology 1989:133, 8-13. 
Bellows CG; Aubin JE; Heersche JN; Antosz ME. Mineralized bone nodules formed in vitro from enzymatically released rat calvaria cell populations. Calcified tissue international 1986:38, 143-54.

Bellows CG; Heersche JN; Aubin JE. Effects of dexamethasone on expression and maintenance of cartilage in serum-containing cultures of calvaria cells. Cell and tissue research 1989:256, 145-51.

Bellows CG; Heersche JN; Aubin JE. Determination of the capacity for proliferation and differentiation of osteoprogenitor cells in the presence and absence of dexamethasone. Developmental biology 1990:140, 132-8.

Bellows CG; Melcher AH; Aubin JE. Contraction and organization of collagen gels by cells cultured from periodontal ligament, gingiva and bone suggest functional differences between cell types. Journal of cell science 1981:50, 299-314.

Beloti MM; Rosa AL. Osteoblast differentiation of human bone marrow cells under continuous and discontinuous treatment with dexametasone. Brazilian dental journal 2005:16, 156-61.

Benatti BB; Silverio KG; Casati MZ; Sallum EA; Nociti FH, Jr. Physiological features of periodontal regeneration and approaches for periodontal tissue engineering utilizing periodontal ligament cells. Journal of bioscience and bioengineering 2007:103, 1-6.

Beningo KA; Dembo M; Wang YL. Responses of fibroblasts to anchorage of dorsal extracellular matrix receptors. Proceedings of the National Academy of Sciences of the United States of America 2004:101, 18024-9.

Beresford JN; Graves SE; Smoothy CA. Formation of mineralized nodules by bone derived cells in vitro: a model of bone formation? American journal of medical genetics 1993:45, 163-78.

Berkovitz BK. Periodontal ligament: structural and clinical correlates. Dental update 2004:31, 46-50, 52, 54.

Berthod F; Hayek D; Damour O; Collombel C. Collagen synthesis by fibroblasts cultured within a collagen sponge. Biomaterials 1993:14, 749-54.

Bhargava U; Bar-Lev M; Bellows CG; Aubin JE. Ultrastructural analysis of bone nodules formed in vitro by isolated fetal rat calvaria cells. Bone 1988:9, 155-63. 
Binderman I; Duksin D; Harell A; Katzir E; Sachs L. Formation of bone tissue in culture from isolated bone cells. The Journal of cell biology 1974:61, 427-39.

Blumenthal NM; Koh-Kunst G; Alves ME; Miranda D; Sorensen RG; Wozney JM; Wikesjo UM. Effect of surgical implantation of recombinant human bone morphogenetic protein-2 in a bioabsorbable collagen sponge or calcium phosphate putty carrier in intrabony periodontal defects in the baboon. Journal of periodontology 2002:73, 1494-506.

Boehrs J; Zaharias RS; Laffoon J; Ko YJ; Schneider GB. Three-dimensional culture environments enhance osteoblast differentiation. Journal of prosthodontics : official journal of the American College of Prosthodontists 2008:17, 517-21.

Bokhari M; Carnachan RJ; Cameron NR; Przyborski SA. Novel cell culture device enabling three-dimensional cell growth and improved cell function. Biochemical and biophysical research communications 2007:354, 1095-100.

Bosetti M; Cannas M. The effect of bioactive glasses on bone marrow stromal cells differentiation. Biomaterials 2005:26, 3873-9.

Bosetti M; Zanardi L; Hench L; Cannas M. Type I collagen production by osteoblastlike cells cultured in contact with different bioactive glasses. Journal of biomedical materials research. Part A 2003:64, 189-95.

Boskey AL. Matrix proteins and mineralization: an overview. Connective tissue research 1996:35, 357-63.

Botchwey EA; Pollack SR; Levine EM; Laurencin CT. Bone tissue engineering in a rotating bioreactor using a microcarrier matrix system. Journal of biomedical materials research 2001:55, 242-53.

Boukhechba F; Balaguer T; Michiels JF; Ackermann K; Quincey D; Bouler JM; Pyerin W; Carle GF; Rochet N. Human primary osteocyte differentiation in a 3D culture system. Journal of bone and mineral research : the official journal of the American Society for Bone and Mineral Research 2009:24, 1927-35.

Bronckers AL; Farach-Carson MC; Van Waveren E; Butler WT. Immunolocalization of osteopontin, osteocalcin, and dentin sialoprotein during dental root formation and early cementogenesis in the rat. Journal of bone and mineral research : the official journal of the American Society for Bone and Mineral Research 1994:9, 833-41.

Busa WB; Nuccitelli R. Metabolic regulation via intracellular $\mathrm{pH}$. The American journal of physiology 1984:246, R409-38. 
Carinci F; Palmieri A; Martinelli M; Perrotti V; Piattelli A; Brunelli G; Arlotti M; Pezzetti F. Genetic portrait of osteoblast-like cells cultured on PerioGlas. The Journal of oral implantology 2007:33, 327-33.

Carnes DL; Maeder CL; Graves DT. Cells with osteoblastic phenotypes can be explanted from human gingiva and periodontal ligament. Journal of periodontology 1997:68, 701-7.

Carvalho SM; Oliveira AA; Jardim CA; Melo CB; Gomes DA; Leite MD; Pereira MM. Characterization and induction of cementoblast cell proliferation by bioactive glass nanoparticles. J Tissue Eng Regen Med 2011,

Casser-Bette M; Murray AB; Closs El; Erfle V; Schmidt J. Bone formation by osteoblast-like cells in a three-dimensional cell culture. Calcified tissue international 1990:46, 46-56.

Centrella M; Mccarthy TL; Canalis E. Transforming growth factor beta is a bifunctional regulator of replication and collagen synthesis in osteoblast-enriched cell cultures from fetal rat bone. The Journal of biological chemistry 1987:262, 2869-74.

Chen FM; Jin Y. Periodontal tissue engineering and regeneration: current approaches and expanding opportunities. Tissue engineering. Part B, Reviews 2010:16, 219-55.

Chevallay B; Herbage D. Collagen-based biomaterials as 3D scaffold for cell cultures: applications for tissue engineering and gene therapy. Medical \& biological engineering \& computing 2000:38, 211-8.

Chien $\mathrm{HH}$; Lin WL; Cho MI. Interleukin-1beta-induced release of matrix proteins into culture media causes inhibition of mineralization of nodules formed by periodontal ligament cells in vitro. Calcified tissue international 1999:64, 402-13.

Cho MI; Matsuda N; Lin WL; Moshier A; Ramakrishnan PR. In vitro formation of mineralized nodules by periodontal ligament cells from the rat. Calcified tissue international 1992:50, 459-67.

Choi JY; Lee BH; Song KB; Park RW; Kim IS; Sohn KY; Jo JS; Ryoo HM. Expression patterns of bone-related proteins during osteoblastic differentiation in MC3T3-E1 cells. Journal of cellular biochemistry 1996:61, 609-18.

Choi MH; Noh WC; Park JW; Lee JM; Suh JY. Gene expression pattern during osteogenic differentiation of human periodontal ligament cells in vitro. Journal of periodontal \& implant science 2011:41, 167-75. 
Chou AM; Sae-Lim V; Lim TM; Schantz JT; Teoh SH; Chew CL; Hutmacher DW. Culturing and characterization of human periodontal ligament fibroblasts - a preliminary study. . Materials Science and Engineering C 2002:20, 77-83.

Chung KM; Salkin LM; Stein MD; Freedman AL. Clinical evaluation of a biodegradable collagen membrane in guided tissue regeneration. Journal of periodontology 1990:61, 732-6.

Clark AE; Pantano CG; Hench LL. Auger spectroscopic analysis of bioglass corrosion films. J Am Ceram Soc 1976:59, 37-39.

Cukierman E; Pankov R; Stevens DR; Yamada KM. Taking cell-matrix adhesions to the third dimension. Science 2001:294, 1708-12.

Cukierman E; Pankov R; Yamada KM. Cell interactions with three-dimensional matrices. Current opinion in cell biology 2002:14, 633-9.

D'errico JA; Ouyang H; Berry JE; Macneil RL; Strayhorn C; Imperiale MJ; Harris NL; Goldberg $\mathrm{H}$; Somerman MJ. Immortalized cementoblasts and periodontal ligament cells in culture. Bone 1999:25, 39-47.

Daley WP; Peters SB; Larsen M. Extracellular matrix dynamics in development and regenerative medicine. Journal of cell science 2008:121, 255-64.

De Assis AF; Beloti MM; Crippa GE; De Oliveira PT; Morra M; Rosa AL. Development of the osteoblastic phenotype in human alveolar bone-derived cells grown on a collagen type l-coated titanium surface. Clinical oral implants research 2009:20, 240-6.

De Oliveira PT; Nanci A. Nanotexturing of titanium-based surfaces upregulates expression of bone sialoprotein and osteopontin by cultured osteogenic cells. Biomaterials 2004:25, 403-13.

De Oliveira PT; Zalzal SF; Beloti MM; Rosa AL; Nanci A. Enhancement of in vitro osteogenesis on titanium by chemically produced nanotopography. Journal of biomedical materials research. Part A 2007:80, 554-64.

De Oliveira PT; Zalzal SF; Irie K; Nanci A. Early expression of bone matrix proteins in osteogenic cell cultures. The journal of histochemistry and cytochemistry : official journal of the Histochemistry Society 2003:51, 633-41. 
Deforge DH. Evaluation of Bioglass/PerioGlas (Consil) synthetic bone graft particulate in the dog and cat. Journal of veterinary dentistry 1997:14, 141-5.

Doillon CJ; Silver FH; Berg RA. Fibroblast growth on a porous collagen sponge containing hyaluronic acid and fibronectin. Biomaterials 1987:8, 195-200.

Donahue HJ; Li Z; Zhou Z; Yellowley CE. Differentiation of human fetal osteoblastic cells and gap junctional intercellular communication. American journal of physiology. Cell physiology 2000:278, C315-22.

Dong J; Uemura T; Shirasaki Y; Tateishi T. Promotion of bone formation using highly pure porous beta-TCP combined with bone marrow-derived osteoprogenitor cells. Biomaterials 2002:23, 4493-502.

Drury JL; Mooney DJ. Hydrogels for tissue engineering: scaffold design variables and applications. Biomaterials 2003:24, 4337-51.

Duarte WR; limura T; Takenaga K; Ohya K; Ishikawa I; Kasugai S. Extracellular role of S100A4 calcium-binding protein in the periodontal ligament. Biochemical and biophysical research communications 1999:255, 416-20.

Ducheyne P; El-Ghannam A; Shapiro I. Effect of bioactive glass templates on osteoblast proliferation and in vitro synthesis of bone-like tissue. Journal of cellular biochemistry 1994:56, 162-7.

Ducy P; Zhang R; Geoffroy V; Ridall AL; Karsenty G. Osf2/Cbfa1: a transcriptional activator of osteoblast differentiation. Cell 1997:89, 747-54.

Dunlop LL; Hall BK. Relationships between cellular condensation, preosteoblast formation and epithelial-mesenchymal interactions in initiation of osteogenesis. The International journal of developmental biology 1995:39, 357-71.

Effah Kaufmann EA; Ducheyne P; Shapiro IM. Evaluation of osteoblast response to porous bioactive glass (45S5) substrates by RT-PCR analysis. Tissue engineering 2000:6, 19-28.

El-Ghannam A; Ducheyne P; Shapiro IM. Bioactive material template for in vitro synthesis of bone. Journal of biomedical materials research 1995:29, 359-70.

El-Ghannam A; Ducheyne P; Shapiro IM. Formation of surface reaction products on bioactive glass and their effects on the expression of the osteoblastic phenotype and the deposition of mineralized extracellular matrix. Biomaterials 1997a:18, 295-303. 
El-Ghannam A; Ducheyne P; Shapiro IM. Porous bioactive glass and hydroxyapatite ceramic affect bone cell function in vitro along different time lines. Journal of biomedical materials research 1997b:36, 167-80.

Elsdale T; Bard J. Collagen substrata for studies on cell behavior. The Journal of cell biology 1972:54, 626-37.

Even-Ram S; Yamada KM. Cell migration in 3D matrix. Current opinion in cell biology 2005:17, 524-32.

Facer SR; Zaharias RS; Andracki ME; Lafoon J; Hunter SK; Schneider GB. Rotary culture enhances pre-osteoblast aggregation and mineralization. Journal of dental research 2005:84, 542-7.

Fernandes LF; Costa MA; Fernandes MH; Tomas H. Osteoblastic behavior of human bone marrow cells cultured over adsorbed collagen layer, over surface of collagen gels, and inside collagen gels. Connective tissue research 2009:50, 336-46.

Ferrera D; Poggi S; Biassoni C; Dickson GR; Astigiano S; Barbieri O; Favre A; Franzi AT; Strangio A; Federici A; Manduca P. Three-dimensional cultures of normal human osteoblasts: proliferation and differentiation potential in vitro and upon ectopic implantation in nude mice. Bone 2002:30, 718-25.

Fetner AE; Hartigan MS; Low SB. Periodontal repair using Perioglas in nonhuman primates: clinical and histologic observations. Compend Contin Educ Dent 1994:15, 932-9.

Flores MG; Hasegawa M; Yamato M; Takagi R; Okano T; Ishikawa I. Cementumperiodontal ligament complex regeneration using the cell sheet technique. Journal of periodontal research 2008:43, 364-71.

Fonseca MJ; Alsina MA; Reig F. Coating liposomes with collagen ( $\mathrm{Mr} 50,000$ ) increases uptake into liver. Biochimica et biophysica acta 1996:1279, 259-65.

Foppiano S; Marshall SJ; Marshall GW; Saiz E; Tomsia AP. Bioactive glass coatings affect the behavior of osteoblast-like cells. Acta biomaterialia 2007:3, 765-71.

Friedl P; Brocker EB. The biology of cell locomotion within three-dimensional extracellular matrix. Cellular and molecular life sciences : CMLS 2000:57, 41-64.

Froum SJ; Weinberg MA; Tarnow D. Comparison of bioactive glass synthetic bone graft particles and open debridement in the treatment of human periodontal defects. A clinical study. Journal of periodontology 1998:69, 698-709. 
Fujii S; Maeda H; Wada N; Kano Y; Akamine A. Establishing and characterizing human periodontal ligament fibroblasts immortalized by SV40T-antigen and hTERT gene transfer. Cell and tissue research 2006:324, 117-25.

Furusawa T; Mizunuma K. Osteoconductive properties and efficacy of resorbable bioactive glass as a bone grafting material. Implant Dent 1997:6, 93-101.

Ganss B; Kim RH; Sodek J. Bone sialoprotein. Critical reviews in oral biology and medicine : an official publication of the American Association of Oral Biologists 1999:10, 79-98.

Gentleman E; Swain RJ; Evans ND; Boonrungsiman S; Jell G; Ball MD; Shean TA; Oyen ML; Porter A; Stevens MM. Comparative materials differences revealed in engineered bone as a function of cell-specific differentiation. Nature materials 2009:8, 763-70.

Gerber I; Ap Gwynn I. Differentiation of rat osteoblast-like cells in monolayer and micromass cultures. European cells \& materials 2002:3, 19-30.

Gerstenfeld LC; Chipman SD; Kelly CM; Hodgens KJ; Lee DD; Landis WJ. Collagen expression, ultrastructural assembly, and mineralization in cultures of chicken embryo osteoblasts. The Journal of cell biology 1988:106, 979-89.

Giancotti FG; Ruoslahti E. Integrin signaling. Science 1999:285, 1028-32.

Giannobile WV. Periodontal tissue engineering by growth factors. Bone 1996:19, 23S-37S.

Gould TR; Melcher AH; Brunette DM. Migration and division of progenitor cell populations in periodontal ligament after wounding. Journal of periodontal research 1980:15, 20-42.

Grabowski P. Physiology of bone. Endocr Dev 2009:16, 32-48.

Gregory CA; Gunn WG; Peister A; Prockop DJ. An Alizarin red-based assay of mineralization by adherent cells in culture: comparison with cetylpyridinium chloride extraction. Analytical biochemistry 2004:329, 77-84.

Griffith LG. Polymeric biomaterials. Acta Mater 2000:48, 263-77. 
Griffith LG; Naughton G. Tissue engineering--current challenges and expanding opportunities. Science 2002:295, 1009-14.

Grinnell F. Fibroblasts, myofibroblasts, and wound contraction. The Journal of cell biology 1994:124, 401-4.

Grinnell F. Fibroblast-collagen-matrix contraction: growth-factor signalling and mechanical loading. Trends in cell biology 2000:10, 362-5.

Grinnell F. Fibroblast biology in three-dimensional collagen matrices. Trends in cell biology 2003:13, 264-9.

Groeneveld MC; Everts V; Beertsen W. A quantitative enzyme histochemical analysis of the distribution of alkaline phosphatase activity in the periodontal ligament of the rat incisor. Journal of dental research 1993:72, 1344-50.

Haase HR; Ivanovski S; Waters MJ; Bartold PM. Growth hormone regulates osteogenic marker mRNA expression in human periodontal fibroblasts and alveolar bone-derived cells. Journal of periodontal research 2003:38, 366-74.

Hall BK; Miyake T. Divide, accumulate, differentiate: cell condensation in skeletal development revisited. The International journal of developmental biology 1995:39, 881-93.

Hall $\mathrm{H}$. Modified fibrin hydrogel matrices: both, 3D-scaffolds and local and controlled release systems to stimulate angiogenesis. Current pharmaceutical design 2007:13, 3597-607.

Harkness RD. Biological functions of collagen. Biological reviews of the Cambridge Philosophical Society 1961:36, 399-463.

Hay E; Lemonnier J; Modrowski D; Lomri A; Lasmoles F; Marie PJ. N- and Ecadherin mediate early human calvaria osteoblast differentiation promoted by bone morphogenetic protein-2. Journal of cellular physiology 2000:183, 117-28.

Hench LL; Paschall HA. Direct chemical bond of bioactive glass-ceramic materials to bone and muscle. Journal of biomedical materials research 1973:7, 25-42.

Hench LL; Paschall HA. Histochemical responses at a biomaterial's interface. Journal of biomedical materials research 1974a:5, 49-64. 
Hench LL; Paschall HA. Histochemical responses at a biomaterial's interface. Journal of biomedical materials research 1974b:5, 49-64.

Hench LL; Splinter RJ; Allen WC; Greenlee Jr TK. Bonding mechanisms at the interface of ceramic prosthetic materials. Journal of biomedical materials research. Part A 1972:2, 117-41.

Hench LL; Xynos ID; Polak JM. Bioactive glasses for in situ tissue regeneration. Journal of biomaterials science. Polymer edition 2004:15, 543-62.

Hoffman RM. To do tissue culture in two or three dimensions? That is the question. Stem Cells 1993:11, 105-11.

Homaeigohar S; Shokrgozar MA; Sadi AY; Khavandi A; Javadpour J; Hosseinalipour $M$. In vitro evaluation of biocompatibility of beta-tricalcium phosphate-reinforced highdensity polyethylene; an orthopedic composite. Journal of biomedical materials research. Part A 2005:75, 14-22.

Horiuchi K; Amizuka N; Takeshita S; Takamatsu H; Katsuura M; Ozawa H; Toyama Y; Bonewald LF; Kudo A. Identification and characterization of a novel protein, periostin, with restricted expression to periosteum and periodontal ligament and increased expression by transforming growth factor beta. Journal of bone and mineral research : the official journal of the American Society for Bone and Mineral Research 1999:14, 1239-49.

Huang JC; Sakata T; Pfleger LL; Bencsik M; Halloran BP; Bikle DD; Nissenson RA. PTH differentially regulates expression of RANKL and OPG. Journal of bone and mineral research : the official journal of the American Society for Bone and Mineral Research 2004:19, 235-44.

Hubbell JA. Materials as morphogenetic guides $\mathrm{n}$ tissue engineering. Curr. Opin. Biotech. 2003:14, 551-58.

Hughes FJ; Turner W; Belibasakis G; Martuscelli G. Effects of growth factors and cytokines on osteoblast differentiation. Periodontology 2000 2006:41, 48-72.

Hynes RO. Integrins: bidirectional, allosteric signaling machines. Cell 2002:110, 67387.

Ibaraki K; Termine JD; Whitson SW; Young MF. Bone matrix mRNA expression in differentiating fetal bovine osteoblasts. Journal of bone and mineral research : the official journal of the American Society for Bone and Mineral Research 1992:7, 74354. 
Inanc B; Elcin AE; Elcin YM. Osteogenic induction of human periodontal ligament fibroblasts under two- and three-dimensional culture conditions. Tissue engineering 2006:12, 257-66.

Irie K; Zalzal S; Ozawa H; Mckee MD; Nanci A. Morphological and immunocytochemical characterization of primary osteogenic cell cultures derived from fetal rat cranial tissue. The Anatomical record 1998:252, 554-67.

Isaka J; Ohazama A; Kobayashi M; Nagashima C; Takiguchi T; Kawasaki H; Tachikawa T; Hasegawa K. Participation of periodontal ligament cells with regeneration of alveolar bone. Journal of periodontology 2001:72, 314-23.

Ishaug SL; Crane GM; Miller MJ; Yasko AW; Yaszemski MJ; Mikos AG. Bone formation by three-dimensional stromal osteoblast culture in biodegradable polymer scaffolds. Journal of biomedical materials research 1997:36, 17-28.

Ishikawa S; Iwasaki K; Komaki M; Ishikawa I. Role of ascorbic acid in periodontal ligament cell differentiation. Journal of periodontology 2004:75, 709-16.

Ivanovski S; Gronthos S; Shi S; Bartold PM. Stem cells in the periodontal ligament. Oral diseases 2006:12, 358-63.

Ivanovski S; Haase HR; Bartold PM. Expression of bone matrix protein mRNAs by primary and cloned cultures of the regenerative phenotype of human periodontal fibroblasts. Journal of dental research 2001:80, 1665-71.

Iwata T; Yamato M; Zhang Z; Mukobata S; Washio K; Ando T; Feijen J; Okano T; Ishikawa I. Validation of human periodontal ligament-derived cells as a reliable source for cytotherapeutic use. Journal of clinical periodontology 2010:37, 1088-99.

Jacquot J; Spilmont C; Burlet H; Fuchey C; Buisson AC; Tournier JM; Gaillard D; Puchelle E. Glandular-like morphogenesis and secretory activity of human tracheal gland cells in a three-dimensional collagen gel matrix. Journal of cellular physiology 1994:161, 407-18.

Jaiswal N; Haynesworth SE; Caplan Al; Bruder SP. Osteogenic differentiation of purified, culture-expanded human mesenchymal stem cells in vitro. Journal of cellular biochemistry 1997:64, 295-312.

Jamal HH; Aubin JE. CD44 expression in fetal rat bone: in vivo and in vitro analysis. Experimental cell research 1996:223, 467-77. 
Jiang SY; Shu R; Xie YF; Zhang SY. Age-related changes in biological characteristics of human alveolar osteoblasts. Cell proliferation 2010:43, 464-70.

Kaigler D; Mooney D. Tissue engineering's impact on dentistry. Journal of dental education 2001:65, 456-62.

Kale S; Biermann S; Edwards C; Tarnowski C; Morris M; Long MW. Threedimensional cellular development is essential for ex vivo formation of human bone. Nature biotechnology 2000:18, 954-8.

Kao RT; Conte G; Nishimine D; Dault S. Tissue engineering for periodontal regeneration. Journal of the California Dental Association 2005:33, 205-15.

Karatzas S; Zavras A; Greenspan D; Amar S. Histologic observations of periodontal wound healing after treatment with PerioGlas in nonhuman primates. The International journal of periodontics \& restorative dentistry 1999:19, 489-99.

Karsdal MA; Larsen L; Engsig MT; Lou H; Ferreras M; Lochter A; Delaisse JM; Foged NT. Matrix metalloproteinasedependent activation of latent transforming growth factor-beta controls the conversion of osteoblasts into osteocytes by blocking osteoblast apoptosis. . J Biol Chem 2002:277, 44061-67.

Kasugai S; Nagata T; Sodek J. Temporal studies on the tissue compartmentalization of bone sialoprotein (BSP), osteopontin (OPN), and SPARC protein during bone formation in vitro. Journal of cellular physiology 1992:152, 467-77.

Kato C; Kojima T; Komaki M; Mimori K; Duarte WR; Takenaga K; Ishikawa I. S100A4 inhibition by RNAi up-regulates osteoblast related genes in periodontal ligament cells. Biochemical and biophysical research communications 2005:326, 147-53.

Katzburg S; Lieberherr M; Ornoy A; Klein BY; Hendel D; Somjen D. Isolation and hormonal responsiveness of primary cultures of human bone-derived cells: gender and age differences. Bone 1999:25, 667-73.

Kaufmann EA; Ducheyne P; Shapiro IM. Effect of varying physical properties of porous, surface modified bioactive glass $45 \mathrm{~S} 5$ on osteoblast proliferation and maturation. Journal of biomedical materials research 2000:52, 783-96.

Kern B; Shen J; Starbuck M; Karsenty G. Cbfa1 contributes to the osteoblast-specific expression of type I collagen genes. The Journal of biological chemistry 2001:276, 7101-7. 
Kim BS; Mooney DJ. Development of biocompatible synthetic extracellular matrices for tissue engineering. Trends in biotechnology 1998:16, 224-30.

Ko YJ; Zaharias RS; Seabold DA; Lafoon J; Schneider GB. Osteoblast differentiation is enhanced in rotary cell culture simulated microgravity environments. Journal of prosthodontics : official journal of the American College of Prosthodontists 2007:16, 431-8.

Komori T; Yagi H; Nomura S; Yamaguchi A; Sasaki K; Deguchi K; Shimizu Y; Bronson RT; Gao YH; Inada M; Sato M; Okamoto R; Kitamura Y; Yoshiki S; Kishimoto T. Targeted disruption of Cbfa1 results in a complete lack of bone formation owing to maturational arrest of osteoblasts. Cell 1997:89, 755-64.

Kono T; Tanii T; Furukawa M; Mizuno N; Kitajima J; Ishii M; Hamada T; Yoshizato K. Parallel arrangement, growth inhibition and cell cycle phase analysis of human dermal fibroblasts cultured in collagen lattice. The Journal of dermatology 1990:17, 210.

Kubo K; Kakimoto T; Kanda C; Tsukasa N; Uehara M; Izumi Y; Kamada T; Kaneko $\mathrm{N}$; Sueda T. Bioactive glass promoted formation of nodules in periodontal-ligament fibroblasts in vitro. Journal of biomedical materials research 1993:27, 1175-80.

Kubo K; Kamada T; Matsuyama T; Tsukasa N; Uehara M; Izumi Y; Kitano M; Ogino $\mathrm{M}$; Sueda T. Characterization of nodules induced by bioactive glass on cultured periodontal-ligament fibroblasts. Journal of biomedical materials research 1995:29, 503-9.

Kubo K; Tsukasa N; Uehara M; Izumi Y; Ogino M; Kitano M; Sueda T. Calcium and silicon from bioactive glass concerned with formation of nodules in periodontalligament fibroblasts in vitro. Journal of oral rehabilitation 1997:24, 70-5.

Kurata K; Heino TJ; Higaki $\mathrm{H}$; Vaananen HK. Bone marrow cell differentiation induced by mechanically damaged osteocytes in 3D gel-embedded culture. Journal of bone and mineral research : the official journal of the American Society for Bone and Mineral Research 2006:21, 616-25.

Kuru L; Griffiths GS; Petrie A; Olsen I. Alkaline phosphatase activity is upregulated in regenerating human periodontal cells. Journal of periodontal research 1999:34, 1237.

Lallier TE; Spencer A. Use of microarrays to find novel regulators of periodontal ligament fibroblast differentiation. Cell and tissue research 2007:327, 93-109. 
Langer R; Vacanti JP. Tissue engineering. Science 1993:260, 920-6.

Lavik E; Langer R. Tissue engineering: current state and perspectives. Appl Microbiol Biotechnol 2004:65, 1-8.

Lee $\mathrm{CH}$; Singla A; Lee Y. Biomedical applications of collagen. International journal of pharmaceutics 2001a:221, 1-22.

Lee J; Cuddihy MJ; Kotov NA. Three-dimensional cell culture matrices: state of the art. Tissue engineering. Part B, Reviews 2008:14, 61-86.

Lee YM; Seol YJ; Lim YT; Kim S; Han SB; Rhyu IC; Baek SH; Heo SJ; Choi JY; Klokkevold PR; Chung CP. Tissue-engineered growth of bone by marrow cell transplantation using porous calcium metaphosphate matrices. Journal of biomedical materials research 2001b:54, 216-23.

Lee YM; Shin SI; Shin KS; Lee YR; Park BH; Kim EC. The role of sirtuin 1 in osteoblastic differentiation in human periodontal ligament cells. Journal of periodontal research 2011:46, 712-21.

Lekic P; Mcculloch CA. Periodontal ligament cell population: the central role of fibroblasts in creating a unique tissue. The Anatomical record 1996:245, 327-41.

Lekic P; Rojas J; Birek C; Tenenbaum H; Mcculloch CA. Phenotypic comparison of periodontal ligament cells in vivo and in vitro. Journal of periodontal research 2001:36, 71-9.

Lekic P; Sodek J; Mcculloch CA. Osteopontin and bone sialoprotein expression in regenerating rat periodontal ligament and alveolar bone. The Anatomical record 1996:244, 50-8.

Lekic PC; Pender N; Mcculloch CA. Is fibroblast heterogeneity relevant to the health, diseases, and treatments of periodontal tissues? Critical reviews in oral biology and medicine : an official publication of the American Association of Oral Biologists 1997:8, 253-68.

Lemonnier J; Hay E; Delannoy P; Lomri A; Modrowski D; Caverzasio J; Marie PJ. Role of $\mathrm{N}$-cadherin and protein kinase $\mathrm{C}$ in osteoblast gene activation induced by the S252W fibroblast growth factor receptor 2 mutation in Apert craniosynostosis. Journal of bone and mineral research : the official journal of the American Society for Bone and Mineral Research 2001:16, 832-45. 
Lewus KE; Nauman EA. In vitro characterization of a bone marrow stem cell-seeded collagen gel composite for soft tissue grafts: effects of fiber number and serum concentration. Tissue engineering 2005:11, 1015-22.

Lian JB; Stein GS. Concepts of osteoblast growth and differentiation: basis for modulation of bone cell development and tissue formation. Critical reviews in oral biology and medicine : an official publication of the American Association of Oral Biologists 1992:3, 269-305.

Liu F; Malaval L; Aubin JE. Global amplification polymerase chain reaction reveals novel transitional stages during osteoprogenitor differentiation. Journal of cell science 2003:116, 1787-96.

Liu HW; Yacobi R; Savion N; Narayanan AS; Pitaru S. A collagenous cementum-derived attachment protein is a marker for progenitors of the mineralized tissue-forming cell lineage of the periodontal ligament. Journal of bone and mineral research : the official journal of the American Society for Bone and Mineral Research 1997:12, 1691-9.

Livak KJ; Schmittgen TD. Analysis of relative gene expression data using real-time quantitative PCR and the 2(-Delta Delta C(T)) Method. Methods 2001:25, 402-8.

Lode A; Bernhardt A; Gelinsky M. Cultivation of human bone marrow stromal cells on three-dimensional scaffolds of mineralized collagen: influence of seeding density on colonization, proliferation and osteogenic differentiation. Journal of tissue engineering and regenerative medicine 2008:2, 400-7.

Lossdorfer S; Fiekens D; Salik MI; Gotz W; Jager A. Subculture affects the phenotypic expression of human periodontal ligament cells and their response to fibroblast growth factor-2 and bone morphogenetic protein-7 in vitro. Journal of periodontal research 2008:43, 563-9.

Loty C; Sautier JM; Tan MT; Oboeuf M; Jallot E; Boulekbache H; Greenspan D; Forest $\mathrm{N}$. Bioactive glass stimulates in vitro osteoblast differentiation and creates a favorable template for bone tissue formation. Journal of bone and mineral research : the official journal of the American Society for Bone and Mineral Research 2001:16, 231-9.

Lowry OH; Rosebrough NJ; Farr AL; Randall RJ. Protein measurement with the Folin phenol reagent. The Journal of biological chemistry 1951:193, 265-75.

Lu HH; El-Amin SF; Scott KD; Laurencin CT. Three-dimensional, bioactive, biodegradable, polymer-bioactive glass composite scaffolds with improved mechanical properties support collagen synthesis and mineralization of human osteoblast-like cells in vitro. Journal of biomedical materials research. Part A 2003:64, 465-74. 
Lynch MP; Capparelli C; Stein JL; Stein GS; Lian JB. Apoptosis during bone-like tissue development in vitro. Journal of cellular biochemistry 1998:68, 31-49.

Lynch MP; Stein JL; Stein GS; Lian JB. The influence of type I collagen on the development and maintenance of the osteoblast phenotype in primary and passaged rat calvarial osteoblasts: modification of expression of genes supporting cell growth, adhesion, and extracellular matrix mineralization. Experimental cell research 1995:216, 35-45.

Malaval L; Liu F; Roche P; Aubin JE. Kinetics of osteoprogenitor proliferation and osteoblast differentiation in vitro. Journal of cellular biochemistry 1999:74, 616-27.

Mancini L; Tamma R; Settanni M; Camerino C; Patano N; Greco G; Strippoli M; Zallone A. Osteoblasts cultured on three-dimensional synthetic hydroxyapatite implanted on a chick allantochorial membrane induce ectopic bone marrow differentiation. Annals of the New York Academy of Sciences 2007:1116, 306-15.

Marcacci M; Kon E; Moukhachev V; Lavroukov A; Kutepov S; Quarto R; Mastrogiacomo M; Cancedda R. Stem cells associated with macroporous bioceramics for long bone repair: 6- to 7-year outcome of a pilot clinical study. Tissue engineering 2007:13, 947-55.

Mastrogiacomo M; Cancedda R; Quarto R. Effect of different growth factors on the chondrogenic potential of human bone marrow stromal cells. Osteoarthritis and cartilage / OARS, Osteoarthritis Research Society 2001:9 Suppl A, S36-40.

Matsuda T; Davies JE. The in vitro responses of osteoblasts to bioactive glass. Biomaterials 1987:8, 275-84.

Matsuda T; Yamauchi K; Ito G. The influence of bioglass on the growth of fibloblasts. J Biomed Mater Res 1987a:21, 499-507.

Matsuda T; Yamauchi K; Ito G. The influence of bioglass on the growth of fibroblasts. Journal of biomedical materials research 1987b:21, 499-507.

Mauch C; Hatamochi A; Scharffetter K; Krieg T. Regulation of collagen synthesis in fibroblasts within a three-dimensional collagen gel. Experimental cell research 1988:178, 493-503.

Mcculloch CA. Progenitor cell populations in the periodontal ligament of mice. The Anatomical record 1985:211, 258-62. 
Mcculloch CA; Bordin S. Role of fibroblast subpopulations in periodontal physiology and pathology. Journal of periodontal research 1991:26, 144-54.

Mcculloch CA; Melcher $\mathrm{AH}$. Cell density and cell generation in the periodontal ligament of mice. The American journal of anatomy 1983a:167, 43-58.

Mcculloch $\mathrm{CA}$; Melcher $\mathrm{AH}$. Continuous labelling of the periodontal ligament of mice. Journal of periodontal research 1983b:18, 231-41.

Mckee MD; Nanci A. Osteopontin at mineralized tissue interfaces in bone, teeth, and osseointegrated implants: ultrastructural distribution and implications for mineralized tissue formation, turnover, and repair. Microscopy research and technique 1996:33, $141-64$.

Melcher $\mathrm{AH}$. On the repair potential of periodontal tissues. Journal of periodontology 1976:47, 256-60.

Mengel R; Soffner M; Flores-De-Jacoby L. Bioabsorbable membrane and bioactive glass in the treatment of intrabony defects in patients with generalized aggressive periodontitis: results of a 12-month clinical and radiological study. Journal of periodontology 2003:74, 899-908.

Mimori K; Komaki M; Iwasaki K; Ishikawa I. Extracellular signal-regulated kinase 1/2 is involved in ascorbic acid-induced osteoblastic differentiation in periodontal ligament cells. Journal of periodontology 2007:78, 328-34.

Minuth WW; Sittinger M; Kloth S. Tissue engineering: generation of differentiated artificial tissues for biomedical applications. Cell and tissue research 1998:291, 1-11.

Mosmann T. Rapid colorimetric assay for cellular growth and survival: application to proliferation and cytotoxicity assays. J Immunol Methods 1983:65, 55-63.

Moura J; Teixeira LN; Ravagnani C; Peitl O; Zanotto ED; Beloti MM; Panzeri H; Rosa AL; De Oliveira PT. In vitro osteogenesis on a highly bioactive glass-ceramic (Biosilicate). Journal of biomedical materials research. Part A 2007:82, 545-57.

Moursi AM; Damsky CH; Lull J; Zimmerman D; Doty SB; Aota S; Globus RK. Fibronectin regulates calvarial osteoblast differentiation. Journal of cell science 1996:109 ( Pt 6), 1369-80.

Mueller-Klieser W. Three-dimensional cell cultures: from molecular mechanisms to clinical applications. The American journal of physiology 1997:273, C1109-23. 
Muraglia A; Martin I; Cancedda R; Quarto R. A nude mouse model for human bone formation in unloaded conditions. Bone 1998:22, 131S-34S.

Murakami Y; Kojima T; Nagasawa T; Kobayashi H; Ishikawa I. Novel isolation of alkaline phosphatase-positive subpopulation from periodontal ligament fibroblasts. Journal of periodontology 2003:74, 780-6.

Murphy WL; Mooney DJ. Controlled delivery of inductive proteins, plasmid DNA and cells from tissue engineering matrices. Journal of periodontal research 1999:34, 4139.

Nagata T; Bellows CG; Kasugai S; Butler WT; Sodek J. Biosynthesis of bone proteins [SPP-1 (secreted phosphoprotein-1, osteopontin), BSP (bone sialoprotein) and SPARC (osteonectin)] in association with mineralized-tissue formation by fetal-rat calvarial cells in culture. The Biochemical journal 1991:274 ( Pt 2), 513-20.

Naito H; Dohi Y; Zimmermann WH; Tojo T; Takasawa S; Eschenhagen T; Taniguchi $S$. The effect of mesenchymal stem cell osteoblastic differentiation on the mechanical properties of engineered bone-like tissue. Tissue engineering. Part A 2011:17, 23219.

Nakagawa S; Pawelek P; Grinnell F. Extracellular matrix organization modulates fibroblast growth and growth factor responsiveness. Experimental cell research 1989a:182, 572-82.

Nakagawa S; Pawelek P; Grinnell F. Long-term culture of fibroblasts in contracted collagen gels: effects on cell growth and biosynthetic activity. The Journal of investigative dermatology 1989b:93, 792-8.

Nakahara T; Nakamura T; Kobayashi E; Inoue M; Shigeno K; Tabata Y; Eto K; Shimizu Y. Novel approach to regeneration of periodontal tissues based on in situ tissue engineering: effects of controlled release of basic fibroblast growth factor from a sandwich membrane. Tissue engineering 2003:9, 153-62.

Nakahara T; Nakamura T; Kobayashi E; Kuremoto K; Matsuno T; Tabata Y; Eto K; Shimizu Y. In situ tissue engineering of periodontal tissues by seeding with periodontal ligament-derived cells. Tissue engineering 2004:10, 537-44.

Nakamura S; Terashima T; Yoshida T; Iseki S; Takano Y; Ishikawa I; Shinomura T. Identification of genes preferentially expressed in periodontal ligament: specific expression of a novel secreted protein, FDC-SP. Biochemical and biophysical research communications 2005:338, 1197-203. 
Nanci A. Content and distribution of noncollagenous matrix proteins in bone and cementum: relationship to speed of formation and collagen packing density. Journal of structural biology 1999:126, 256-69.

Nanci A; Wuest JD; Peru L; Brunet P; Sharma V; Zalzal S; Mckee MD. Chemical modification of titanium surfaces for covalent attachment of biological molecules. Journal of biomedical materials research 1998:40, 324-35.

Nanci A; Zalzal S; Gotoh Y; Mckee MD. Ultrastructural characterization and immunolocalization of osteopontin in rat calvarial osteoblast primary cultures. Microscopy research and technique 1996:33, 214-31.

Neeley WW; Carnes DL; Cochran DL. Osteogenesis in an in vitro coculture of human periodontal ligament fibroblasts and human microvascular endothelial cells. Journal of periodontology 2010:81, 139-49.

Nefussi JR; Boy-Lefevre ML; Boulekbache $\mathrm{H}$; Forest $\mathrm{N}$. Mineralization in vitro of matrix formed by osteoblasts isolated by collagenase digestion. Differentiation; research in biological diversity 1985:29, 160-8.

Nefussi JR; Brami G; Modrowski D; Oboeuf M; Forest N. Sequential expression of bone matrix proteins during rat calvaria osteoblast differentiation and bone nodule formation in vitro. The journal of histochemistry and cytochemistry : official journal of the Histochemistry Society 1997:45, 493-503.

Nerem RM; Sambanis A. Tissue engineering: from biology to biological substitutes. Tissue engineering 1995:1, 3-13.

Nishiyama T; Tsunenaga M; Nakayama Y; Adachi E; Hayashi T. Growth rate of human fibroblasts is repressed by the culture within reconstituted collagen matrix but not by the culture on the matrix. Matrix 1989:9, 193-9.

Nohutcu RM; Mccauley LK; Koh AJ; Somerman MJ. Expression of extracellular matrix proteins in human periodontal ligament cells during mineralization in vitro. Journal of periodontology 1997:68, 320-7.

Nohutcu RM; Mccauley LK; Shigeyama Y; Somerman MJ. Expression of mineralassociated proteins by periodontal ligament cells: in vitro vs. ex vivo. Journal of periodontal research 1996:31, 369-72.

Nojima N; Kobayashi M; Shionome M; Takahashi N; Suda T; Hasegawa K. Fibroblastic cells derived from bovine periodontal ligaments have the phenotypes of osteoblasts. Journal of periodontal research 1990:25, 179-85. 
Nojima N; Kobayashi M; Shionone M; Takahashi N; Suda T; Hasegawa K. Fibroblastic cells derived from bovine periodontal ligaments have the phenotypes of osteoblasts. Journal of periodontal research 1990 25, 179-85.

Nöth U; Siebenlist S; Rackwitz L; Schreiber B; Steinert A; Barthel T; Eulert J. MatrixBased Autologous Chondrocyte Transplantation for the Treatment of Large Osteochondral Defects. . Touch Briefings 2006, 62-64.

Nusgens B; Merrill C; Lapiere C; Bell E. Collagen biosynthesis by cells in a tissue equivalent matrix in vitro. Collagen and related research 1984:4, 351-63.

Ogata Y; Niisato N; Sakurai T; Furuyama S; Sugiya H. Comparison of the characteristics of human gingival fibroblasts and periodontal ligament cells. Journal of periodontology 1995:66, 1025-31.

Ogino M; Ohuchi F; Hench LL. Compositional dependence of the formation of calcium phosphate films on bioglass. Journal of biomedical materials research 1980:14, 55-64.

Omstead DR; Baird LG; Christenson L; Du Moulin G; Tubo R; Maxted DD; Davis J; Gentile FT. Voluntary guidance for the development of tissue-engineered products. Tissue engineering 1998:4, 239-66.

Ong SM; Zhang C; Toh YC; Kim SH; Foo HL; Tan CH; Van Noort D; Park S; Yu H. A gel-free 3D microfluidic cell culture system. Biomaterials 2008:29, 3237-44.

Oonishi H; Kushitani S; Yasukawa E; Iwaki H; Hench LL; Wilson J; Tsuji E; Sugihara T. Particulate bioglass compared with hydroxyapatite as a bone graft substitute. Clin Orthop 1997:334, 316-25.

Owen ME; Cave J; Joyner CJ. Clonal analysis in vitro of osteogenic differentiation of marrow CFU-F. Journal of cell science 1987:87 ( Pt 5), 731-8.

Owen TA; Aronow M; Shalhoub V; Barone LM; Wilming L; Tassinari MS; Kennedy MB; Pockwinse S; Lian JB; Stein GS. Progressive development of the rat osteoblast phenotype in vitro: reciprocal relationships in expression of genes associated with osteoblast proliferation and differentiation during formation of the bone extracellular matrix. Journal of cellular physiology 1990:143, 420-30.

Ozawa R; Yamada Y; Nagasaka T; Ueda M. A comparison of osteogenesis-related gene expression of mesenchymal stem cells during the osteoblastic differentiation induced by type-I collagen and/or fibronectin Int J Oral Med Sci 2003:1, 139-46. 
Pankov R; Endo Y; Even-Ram S; Araki M; Clark K; Cukierman E; Matsumoto K; Yamada KM. A Rac switch regulates random versus directionally persistent cell migration. The Journal of cell biology 2005:170, 793-802.

Park JS; Suh JJ; Choi SH; Moon IS; Cho KS; Kim CK; Chai JK. Effects of pretreatment clinical parameters on bioactive glass implantation in intrabony periodontal defects. Journal of periodontology 2001:72, 730-40.

Parkar MH; Kuru L; O'hare M; Newman HN; Hughes F; Olsen I. Retroviral transduction of human periodontal cells with a temperature-sensitive SV40 large T antigen. Archives of oral biology 1999:44, 823-34.

Pender N; Mcculloch CA. Quantitation of actin polymerization in two human fibroblast sub-types responding to mechanical stretching. Journal of cell science 1991:100 ( Pt 1), 187-93.

Pereira MM; Clark AE; Hench LL. Calcium phosphate formation on sol-gel-derived bioactive glasses in vitro. Journal of biomedical materials research 1994:28, 693-8.

Pi SH; Lee SK; Hwang YS; Choi MG; Kim EC. Differential expression of periodontal ligament-specific markers and osteogenic differentiation in human papilloma virus 16immortalized human gingival fibroblasts and periodontal ligament cells. Journal of periodontal research 2007:42, 104-13.

Piche JE; Carnes DL, Jr.; Graves DT. Initial characterization of cells derived from human periodontia. Journal of dental research 1989:68, 761-7.

Pitaru S; Mcculloch CA; Narayanan SA. Cellular origins and differentiation control mechanisms during periodontal development and wound healing. Journal of periodontal research 1994:29, 81-94.

Pockwinse SM; Wilming LG; Conlon DM; Stein GS; Lian JB. Expression of cell growth and bone specific genes at single cell resolution during development of bone tissue-like organization in primary osteoblast cultures. Journal of cellular biochemistry 1992:49, 310-23.

Price N; Bendall SP; Frondoza C; Jinnah RH; Hungerford DS. Human osteoblast-like cells (MG63) proliferate on a bioactive glass surface. Journal of biomedical materials research 1997:37, 394-400.

Puleo DA; Nanci A. Understanding and controlling the bone-implant interface. Biomaterials 1999:20, 2311-21. 
Quarto R; Mastrogiacomo M; Cancedda R; Kutepov SM; Mukhachev V; Lavroukov A; Kon E; Marcacci M. Repair of large bone defects with the use of autologous bone marrow stromal cells. N Engl J Med 2001:344, 385-6.

Radin S; Reilly G; Bhargave G; Leboy PS; Ducheyne P. Osteogenic effects of bioactive glass on bone marrow stromal cells. Journal of biomedical materials research. Part A 2005:73, 21-9.

Reilly GC; Radin S; Chen AT; Ducheyne P. Differential alkaline phosphatase responses of rat and human bone marrow derived mesenchymal stem cells to 45S5 bioactive glass. Biomaterials 2007:28, 4091-7.

Riccio M; Resca E; Maraldi T; Pisciotta A; Ferrari A; Bruzzesi G; De Pol A. Human dental pulp stem cells produce mineralized matrix in 2D and 3D cultures. European journal of histochemistry : EJH 2010:54, e46.

Ripamonti V; Renton L. Proteínas morfogenéticas ósseas e a indução da regeneração no tecido periodontal. Periodontologia 2000 2008:15, 73-87.

Roberts WE; Jee WS. Cell kinetics of orthodontically-stimulated and non-stimulated periodontal ligament in the rat. Archives of oral biology 1974:19, 17-21.

Roberts WE; Morey ER. Proliferation and differentiation sequence of osteoblast histogenesis under physiological conditions in rat periodontal ligament. The American journal of anatomy 1985:174, 105-18.

Roberts WE; Wood HB; Chambers DW; Burk DT. Vascularly oriented differentiation gradient of osteoblast precursor cells in rat periodontal ligament: implications for osteoblast histogenesis and periodontal bone loss. Journal of periodontal research 1987:22, 461-7.

Robison R. The Possible Significance of Hexosephosphoric Esters in Ossification. The Biochemical journal 1923:17, 286-93.

Roriz VM; Rosa AL; Peitl O; Zanotto ED; Panzeri H; De Oliveira PT. Efficacy of a bioactive glass-ceramic (Biosilicate) in the maintenance of alveolar ridges and in osseointegration of titanium implants. Clinical oral implants research 2010:21, 14855.

Rosa AL; Beloti MM. Effect of cpTi surface roughness on human bone marrow cell attachment, proliferation and differentiation. Brazilian dental journal 2003:14, 16-21. 
Rosso F; Giordano A; Barbarisi M; Barbarisi A. From cell-ECM interactions to tissue engineering. Journal of cellular physiology 2004:199, 174-80.

Rucci N; Migliaccio S; Zani BM; Taranta A; Teti A. Characterization of the osteoblastlike cell phenotype under microgravity conditions in the NASA-approved Rotating Wall Vessel bioreactor (RWV). Journal of cellular biochemistry 2002:85, 167-79.

Rutherford RB; Ryan ME; Kennedy JE; Tucker MM; Charette MF. Platelet-derived growth factor and dexamethasone combined with a collagen matrix induce regeneration of the periodontium in monkeys. Journal of clinical periodontology 1993:20, 537-44.

Saito Y; Yoshizawa T; Takizawa F; Ikegame M; Ishibashi O; Okuda K; Hara K; Ishibashi K; Obinata M; Kawashima $\mathrm{H}$. A cell line with characteristics of the periodontal ligament fibroblasts is negatively regulated for mineralization and Runx2/Cbfa1/Osf2 activity, part of which can be overcome by bone morphogenetic protein-2. Journal of cell science 2002:115, 4191-200.

Sato Y; Kikuchi M; Ohata N; Tamura M; Kuboki Y. Enhanced cementum formation in experimentally induced cementum defects of the root surface with the application of recombinant basic fibroblast growth factor in collagen gel in vivo. Journal of periodontology 2004:75, 243-8.

Schepers E; De Clercq M; Ducheyne P. Histological and histomorphometrical analysis of bioactive glass and fibre reinforced bioactive glass dental root implants. Journal of oral rehabilitation 1988:15, 473-87.

Schepers E; Ducheyne P; De Clercq M. Interfacial analysis of fiber-reinforced bioactive glass dental root implants. Journal of biomedical materials research 1989:23, 735-52.

Schepers EJ; Ducheyne P. Bioactive glass particles of narrow size range for the treatment of oral bone defects: a 1-24 month experiment with several materials and particle sizes and size ranges. Journal of oral rehabilitation 1997:24, 171-81.

Schilephake $\mathrm{H}$. Bone growth factors in maxillofacial skeletal reconstruction. International journal of oral and maxillofacial surgery 2002:31, 469-84.

Schindler M; Nur EKA; Ahmed I; Kamal J; Liu HY; Amor N; Ponery AS; Crockett DP; Grafe TH; Chung HY; Weik T; Jones E; Meiners S. Living in three dimensions: 3D nanostructured environments for cell culture and regenerative medicine. Cell biochemistry and biophysics 2006:45, 215-27. 
Schmeichel KL; Bissell MJ. Modeling tissue-specific signaling and organ function in three dimensions. Journal of cell science 2003:116, 2377-88.

Schmitt B; Ringe J; Haupl T; Notter M; Manz R; Burmester GR; Sittinger M; Kaps C. BMP2 initiates chondrogenic lineage development of adult human mesenchymal stem cells in high-density culture. Differentiation; research in biological diversity 2003:71, 567-77.

Schroder NW; Meister D; Wolff V; Christan C; Kaner D; Haban V; Purucker P; Hermann C; Moter A; Gobel UB; Schumann RR. Chronic periodontal disease is associated with single-nucleotide polymorphisms of the human TLR-4 gene. Genes and immunity 2005:6, 448-51.

Seo BM; Miura M; Gronthos S; Bartold PM; Batouli S; Brahim J; Young M; Robey PG; Wang CY; Shi S. Investigation of multipotent postnatal stem cells from human periodontal ligament. Lancet 2004:364, 149-55.

Silver IA; Deas J; Erecinska M. Interactions of bioactive glasses with osteoblasts in vitro: effects of $45 \mathrm{~S} 5$ Bioglass, and $58 \mathrm{~S}$ and $77 \mathrm{~S}$ bioactive glasses on metabolism, intracellular ion concentrations and cell viability. Biomaterials 2001:22, 175-85.

Sisken BF; Walker J; Orgel M. Prospects on clinical applications of electrical stimulation for nerve regeneration. Journal of cellular biochemistry 1993:51, 404-9.

Sittinger M; Bujia J; Rotter N; Reitzel D; Minuth WW; Burmester GR. Tissue engineering and autologous transplant formation: practical approaches with resorbable biomaterials and new cell culture techniques. Biomaterials 1996:17, 23742.

Sodek J; Ganss B; Mckee MD. Osteopontin. Critical reviews in oral biology and medicine : an official publication of the American Association of Oral Biologists 2000:11, 279-303.

Somerman MJ; Archer SY; Imm GR; Foster RA. A comparative study of human periodontal ligament cells and gingival fibroblasts in vitro. Journal of dental research 1988a:67, 66-70.

Somerman MJ; Archer SY; Imm GR; Foster RA. A comparative study of human periodontal ligament cells and gingival fibroblasts in vitro. Journal of dental research 1988b:67, 66-70. 
Somerman MJ; Ouyang HJ; Berry JE; Saygin NE; Strayhorn CL; D'errico JA; Hullinger T; Giannobile WV. Evolution of periodontal regeneration: from the roots' point of view. Journal of periodontal research 1999:34, 420-4.

Somerman MJ; Sauk JJ; Foster RA; Norris K; Dickerson K; Argraves WS. Cell attachment activity of cementum: bone sialoprotein II identified in cementum. Journal of periodontal research 1991:26, 10-6.

Somerman MJ; Young MF; Foster RA; Moehring JM; Imm G; Sauk JJ. Characteristics of human periodontal ligament cells in vitro. Archives of oral biology 1990:35, 241-7.

Srisuwan T; Tilkorn DJ; Wilson JL; Morrison WA; Messer HM; Thompson EW; Abberton KM. Molecular aspects of tissue engineering in the dental field. Periodontology 2000 2006:41, 88-108.

Stein GS; Lian JB. Molecular mechanisms mediating proliferation/differentiation interrelationships during progressive development of the osteoblast phenotype. Endocrine reviews 1993:14, 424-42.

Steinberg BM; Smith K; Colozzo M; Pollack R. Establishment and transformation diminish the ability of fibroblasts to contract a native collagen gel. The Journal of cell biology 1980:87, 304-8.

Sun JY; Yang YS; Zhong J; Greenspan DC. The effect of the ionic products of Bioglass dissolution on human osteoblasts growth cycle in vitro. Journal of tissue engineering and regenerative medicine 2007:1, 281-6.

Taba M, Jr.; Jin Q; Sugai JV; Giannobile WV. Current concepts in periodontal bioengineering. Orthodontics \& craniofacial research 2005:8, 292-302.

Tadjoedin ES; De Lange GL; Holzmann PJ; Kulper L; Burger EH. Histological observations on biopsies harvested following sinus floor elevation using a bioactive glass material of narrow size range. Clinical oral implants research 2000:11, 334-44.

Tessmar JK; Gopferich AM. Matrices and scaffolds for protein delivery in tissue engineering. Advanced drug delivery reviews 2007:59, 274-91.

Thie M; Schlumberger W; Rauterberg J; Robenek H. Mechanical confinement inhibits collagen synthesis in gel-cultured fibroblasts. European journal of cell biology 1989:48, 294-302. 
Thomas GP; Baker SU; Eisman JA; Gardiner EM. Changing RANKL/OPG mRNA expression in differentiating murine primary osteoblasts. The Journal of endocrinology 2001:170, 451-60.

Trojani C; Weiss P; Michiels JF; Vinatier C; Guicheux J; Daculsi G; Gaudray P; Carle GF; Rochet N. Three-dimensional culture and differentiation of human osteogenic cells in an injectable hydroxypropylmethylcellulose hydrogel. Biomaterials 2005:26, 5509-17.

Tsigkou O; Jones JR; Polak JM; Stevens MM. Differentiation of fetal osteoblasts and formation of mineralized bone nodules by $45 S 5$ Bioglass conditioned medium in the absence of osteogenic supplements. Biomaterials 2009:30, 3542-50.

Uemura T; Dong J; Wang Y; Kojima H; Saito T; lejima D; Kikuchi M; Tanaka J; Tateishi T. Transplantation of cultured bone cells using combinations of scaffolds and culture techniques. Biomaterials 2003:24, 2277-86.

Vacanti CA; Langer R; Schloo B; Vacanti JP. Synthetic polymers seeded with chondrocytes provide a template for new cartilage formation. Plastic and reconstructive surgery 1991:88, 753-9.

Van Den Dolder J; Jansen JA. The response of osteoblast-like cells towards collagen type I coating immobilized by p-nitrophenylchloroformate to titanium. Journal of biomedical materials research. Part A 2007:83, 712-9.

Varanasi VG; Owyoung JB; Saiz E; Marshall SJ; Marshall GW; Loomer PM. The ionic products of bioactive glass particle dissolution enhance periodontal ligament fibroblast osteocalcin expression and enhance early mineralized tissue development. Journal of biomedical materials research. Part A 2011:98, 177-84.

Varanasi VG; Saiz E; Loomer PM; Ancheta B; Uritani N; Ho SP; Tomsia AP; Marshall SJ; Marshall GW. Enhanced osteocalcin expression by osteoblast-like cells (MC3T3$\mathrm{E} 1$ ) exposed to bioactive coating glass ( $\mathrm{SiO} 2-\mathrm{CaO}-\mathrm{P} 2 \mathrm{O} 5-\mathrm{MgO}-\mathrm{K} 2 \mathrm{O}-\mathrm{Na} 2 \mathrm{O}$ system) ions. Acta biomaterialia 2009:5, 3536-47.

Velazquez OC; Snyder R; Liu ZJ; Fairman RM; Herlyn M. Fibroblast-dependent differentiation of human microvascular endothelial cells into capillary-like 3dimensional networks. FASEB journal : official publication of the Federation of American Societies for Experimental Biology 2002:16, 1316-8.

Villaca JH; Novaes AB, Jr.; Souza SL; Taba M, Jr.; Molina GO; Carvalho TL. Bioactive glass efficacy in the periodontal healing of intrabony defects in monkeys. Brazilian dental journal 2005:16, 67-74. 
Vrouwenvelder WC; Groot CG; De Groot K. Behaviour of fetal rat osteoblasts cultured in vitro on bioactive glass and nonreactive glasses. Biomaterials 1992:13, 382-92.

Vrouwenvelder WC; Groot CG; De Groot K. Histological and biochemical evaluation of osteoblasts cultured on bioactive glass, hydroxylapatite, titanium alloy, and stainless steel. Journal of biomedical materials research 1993:27, 465-75.

Vrouwenvelder WC; Groot CG; De Groot K. Better histology and biochemistry for osteoblasts cultured on titanium-doped bioactive glass: bioglass $45 S 5$ compared with iron-, titanium-, fluorine- and boron-containing bioactive glasses. Biomaterials 1994:15, 97-106.

Vukicevic S; Luyten FP; Kleinman HK; Reddi AH. Differentiation of canalicular cell processes in bone cells by basement membrane matrix components: regulation by discrete domains of laminin. Cell 1990:63, 437-45.

Wang HL; Pappert TD; Castelli WA; Chiego DJ, Jr.; Shyr Y; Smith BA. The effect of platelet-derived growth factor on the cellular response of the periodontium: an autoradiographic study on dogs. Journal of periodontology 1994:65, 429-36.

Weinand C; Pomerantseva I; Neville CM; Gupta R; Weinberg E; Madisch I; Shapiro F; Abukawa H; Troulis MJ; Vacanti JP. Hydrogel-beta-TCP scaffolds and stem cells for tissue engineering bone. Bone 2006:38, 555-63.

Wheeler DL; Stokes KE; Park HM; Hollinger JO. Evaluation of particulate Bioglass in a rabbit radius ostectomy model. Journal of biomedical materials research 1997:35, 249-54.

Wilson J; Low SB. Bioactive ceramics for periodontal treatment: comparative studies in the Patus monkey. Journal of applied biomaterials : an official journal of the Society for Biomaterials 1992:3, 123-9.

Witte RP; Kao WJ. Keratinocyte-fibroblast paracrine interaction: the effects of substrate and culture condition. Biomaterials 2005:26, 3673-82.

Woltgens JH; Bervoets TJ; Bronckers AL; Lyaruu DM. Organ culture of tooth germs: relationship between alkaline phosphatase and mineralization in vitro. Journal de biologie buccale 1982:10, 191-8.

Wozniak MA; Desai R; Solski PA; Der CJ; Keely PJ. ROCK-generated contractility regulates breast epithelial cell differentiation in response to the physical properties of a three-dimensional collagen matrix. The Journal of cell biology 2003:163, 583-95. 
Wozniak MA; Modzelewska K; Kwong L; Keely PJ. Focal adhesion regulation of cell behavior. Biochimica et biophysica acta 2004:1692, 103-19.

Xiao Y; Qian H; Young WG; Bartold PM. Tissue engineering for bone regeneration using differentiated alveolar bone cells in collagen scaffolds. Tissue engineering 2003:9, 1167-77.

Xu T; Molnar P; Gregory C; Das M; Boland T; Hickman JJ. Electrophysiological characterization of embryonic hippocampal neurons cultured in a 3D collagen hydrogel. Biomaterials 2009:30, 4377-83.

Xynos ID; Edgar AJ; Buttery LD; Hench LL; Polak JM. Gene-expression profiling of human osteoblasts following treatment with the ionic products of Bioglass 45S5 dissolution. Journal of biomedical materials research 2001:55, 151-7.

Xynos ID; Hukkanen MV; Batten JJ; Buttery LD; Hench LL; Polak JM. Bioglass $45 S 5$ stimulates osteoblast turnover and enhances bone formation In vitro: implications and applications for bone tissue engineering. Calcified tissue international 2000:67, 321-9.

Yang Y; El Haj AJ. Biodegradable scaffolds--delivery systems for cell therapies. Expert Opin Biol Ther 2006:6, 485-98.

Yao KL; Todescan R, Jr.; Sodek J. Temporal changes in matrix protein synthesis and mRNA expression during mineralized tissue formation by adult rat bone marrow cells in culture. Journal of bone and mineral research : the official journal of the American Society for Bone and Mineral Research 1994:9, 231-40.

Yefang Z; Hutmacher DW; Varawan SL; Meng LT. Comparison of human alveolar osteoblasts cultured on polymer-ceramic composite scaffolds and tissue culture plates. International journal of oral and maxillofacial surgery 2007:36, 137-45.

Yokoyama A; Sekiya I; Miyazaki K; Ichinose S; Hata Y; Muneta T. In vitro cartilage formation of composites of synovium-derived mesenchymal stem cells with collagen gel. Cell and tissue research 2005:322, 289-98.

Yoshikawa $\mathrm{T}$; Ohgushi $\mathrm{H}$; Tamai $\mathrm{S}$. Immediate bone forming capability of prefabricated osteogenic hydroxyapatite. Journal of biomedical materials research 1996:32, 481-92.

Zaman MH; Trapani LM; Sieminski AL; Mackellar D; Gong H; Kamm RD; Wells A; Lauffenburger DA; Matsudaira P. Migration of tumor cells in 3D matrices is governed by matrix stiffness along with cell-matrix adhesion and proteolysis. Proc Natl Acad Sci U S A 2006:103, 10889-94. 
Zohar R; Cheifetz S; Mcculloch CA; Sodek J. Analysis of intracellular osteopontin as a marker of osteoblastic cell differentiation and mesenchymal cell migration. Eur $\mathrm{J}$ Oral Sci 1998:106 Suppl 1, 401-7.

Zohar R; Lee W; Arora P; Cheifetz S; Mcculloch C; Sodek J. Single cell analysis of intracellular osteopontin in osteogenic cultures of fetal rat calvarial cells. Journal of cellular physiology 1997:170, 88-100. 
Anexos 
ANEXO A - Carta de aprovação do comitê de ética em animais.

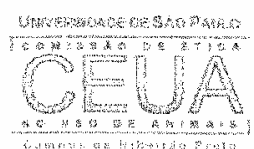

\author{
UNIVERSIDADE DE SÃO PAULO \\ Campus de Ribeirão Preto \\ Comissão de Etica no Uso de Animais
}

\title{
C E R T I F I C A D O
}

Certificamos que o trabalho (Protocolo $n^{\circ}$ 09.1.1210.53.0), intitulado "Expressão dos Fenótipos Fibroblásticos e Osteoblástico em Culturas Tridimensionais na Presença, ou não, de Partículas de Vidro Bioativo", de autoria de Daniela Bazan Palioto por estar de acordo com os Principios Éticos na Experimentação Animal adotado pela Comissão de Ética no Uso de Animais (CEUA) do Campus de Ribeirão Preto - USP foi aprovado em reunião da CEUA de 02/02/2010.

This is to certify that the work (Protocol number 09.1.1210.53.0), entitled: Expressão dos Fenótipos Fibroblásticos e Osteoblástico em Culturas Tridimensionais na Presença ou não de Particulas de Vidro Bioativo", by Daniela Bazan Palioto, is in accordance with the Ethic Principles in Animal Experimentation adopted by Ethic Commission for the Use of Animals (CEUA) of the Campus of Ribeirão Preto - USP, and was approved in the meeting, February 02, 2010.

Ribeirão Preto, 19 de fevereiro de 2010.

Presidente da CEUA

Profa.Dra. Christie Ramos Andrade Leite Panissi

Secretária dá CEUA

Maria Angélica Depiro

Av. Bandeirantes, 3900 - CEP $14040-900$ - Ribeirão Preto - Săo Paulo Fone (16) 36024469 - Fax: (16) 36337964 
ANEXO B - Carta de aprovação do comitê de ética em humanos.

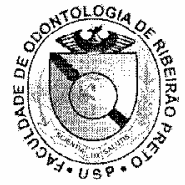

Of. CEP/033/FORP/190210

\section{UNIVERSIDADE DE SÃO PAULO}

Faculdade de Odontologia de Ribeirão Preto

Comitê de Ética em Pesquisa

Ref. processo n. ${ }^{\circ}$ 2009.1.1206.58.3 CAAE n. ${ }^{\circ} 0083.0 .138 .000-09$

Senhora Pesquisadora:

Por solicitação da Prof. ${ }^{a}$ Dr. ${ }^{a}$ Cláudia Helena Lovato da Silva, Coordenadora do Comitê de Ética em Pesquisa, informamos que o referido Comitê, em sua 106. a Sessāo, realizada ans 11 de fevereirn de 2010, aprovou o projeto de pesquisa "Expressão dos fenótipos fibroblảstico e osteoblástico em culturas tridimensionais na presença ou não de partículas de vidro bioativo".

$\mathrm{Na}$ oportunidade, lembramos da necessidade de serem entregues na secretaria do CEP os Relatórios Parcial e Final, com o respectivo formulário preenchido pelo pesquisador responsável, em 13 de dezembro de 2010 e 13 de setembro de 2011 , respectivamente.

DANIEL MESQUITA DE MORAES

Secretărio do Comitê de Ética em Pesquisa

$\operatorname{Ilm}{ }^{{ }^{A}} \mathrm{Sr}^{{ }^{a}}$

\section{Prof. ${ }^{a}$ Dr. ${ }^{a}$ DANIELA BAZAN PALIOTO BULlE}

Departamento de Cirurgia e Traumatologia Buco-Maxilo-Facial e Periodontia desta Faculdade 